\title{
Diversifying Business Development: Exploring Opportunities to Attract Latino Entrepreneurs to West Virginia
}

\author{
Juan Carlos Arcila Naranjo \\ West Virginia University
}

Follow this and additional works at: https://researchrepository.wvu.edu/etd

\section{Recommended Citation}

Arcila Naranjo, Juan Carlos, "Diversifying Business Development: Exploring Opportunities to Attract Latino Entrepreneurs to West Virginia" (2013). Graduate Theses, Dissertations, and Problem Reports. 435.

https://researchrepository.wvu.edu/etd/435

This Dissertation is protected by copyright and/or related rights. It has been brought to you by the The Research Repository @ WVU with permission from the rights-holder(s). You are free to use this Dissertation in any way that is permitted by the copyright and related rights legislation that applies to your use. For other uses you must obtain permission from the rights-holder(s) directly, unless additional rights are indicated by a Creative Commons license in the record and/ or on the work itself. This Dissertation has been accepted for inclusion in WVU Graduate Theses, Dissertations, and Problem Reports collection by an authorized administrator of The Research Repository @ WVU.

For more information, please contact researchrepository@mail.wvu.edu. 


\title{
Diversifying Business Development: Exploring Opportunities to Attract Latino Entrepreneurs to West Virginia
}

\author{
Juan Carlos Arcila Naranjo \\ Dissertation submitted to the \\ Davis College of Agriculture, Natural Resources and Design \\ at West Virginia University \\ in partial fulfillment of the requirements \\ for the degree of \\ Doctor of Philosophy \\ In \\ Human and Community Development
Barbara McFall, Ph.D, Chair Cindy Beacham, Ph.D. Kristina Oliver Clement Solomon, Ph. D. \\ Kathryn Eason, Ph.D. \\ Division of Design and Merchandising \\ Division of Resource Management \\ Morgantown, West Virginia \\ 2013
}

Keywords: Latino, Entrepreneurship, Development, Growth, West Virginia, Small Business

Copyright @2013 Juan C. Arcila N. 


\title{
ABSTRACT \\ Diversifying Business Development: Exploring Opportunities to Attract Latino Entrepreneurs to West Virginia
}

\author{
Juan C. Arcila N.
}

Prior studies have examined Latino entrepreneurship in a variety of settings in which Latinos are a significant population. Some of the previously identified barriers to successful Latino entrepreneurship include financial funding, racial issues, ethnic enclaves, and getting along with people from other cultures. This study builds upon that tradition by exploring Latino business owners in West Virginia. The study will address the following research questions:

- Why are there so few Latino Entrepreneurs in West Virginia?

- What are the entrepreneurial issues identified by Latino business owners in West Virginia?

This research was done with two main objectives in mind: To help potential Latino and non-Latino business owners in West Virginia to start their business more efficiently; and find out how to mitigate the issues and obstacles that are presented to Latino Entrepreneurs in West Virginia.

A brief comparison of the behaviors and experience of Latino entrepreneurs and majority entrepreneurs in the United States highlights the differences that exist between the two.

The study was delimited to current, legal, first-generation Latinos and their descendants as identified by the U.S Census Bureau in West Virginia. According to the U.S Census Bureau there are around 84 Latino Business owners in the state. Eight individual interviews represented around 10 percent of the population yielding credible and useful findings.

Seven of the business owners interviewed for this research were women, while only one of the participants was a man. The majority of the business owners were between 34 and 50 years of age. The most pressing issues found in this study are: Sense of Community, Expertise level, Governmental support, Trust issues - Discrimination (Perception), and Market Demand.

This research has provided a clear insight into what the major variables for Latino success in the United States are. Some of these variables are definite reasons why Latinos thrive in a certain environment, such as an ethnic enclave and geographic 
location, while other reasons are more potential contribution to such success, like warm weather and a large labor force.

Although the Latino population in the United States is becoming an incredibly strong and valuable asset to the American economy, the state of West Virginia has yet to capitalize on this trend. This study found that it should be possible to bring in more Latino businesses to the state if West Virginia fully embraces Latino businesses as a path to economic diversity, and develops effective support structures to expand the Latino community as well as Latino owned businesses.

Governmental support is critical for Latino business owners that want to start their businesses in West Virginia. However, establishing programs for minorities, and providing funding for potential Latino business owners may not be enough. This research found that the biggest issue regarding governmental support has to do with lack of trust and fear of the government among Latinos.

This preliminary study was created to explore why Latinos are not starting as many business ventures in West Virginia as they do in other states. Future research might focus on other demographics that struggle in the state of West Virginia but thrive in other states and/or extended to include locals with similar demographic.

Keywords: Latinos, entrepreneurship, ethnic conclave, market demand 


\section{DEDICATION}

I would like to dedicate this work to my wonderful and loving wife, and best friend Paola, my amazing parents José Reinaldo y María Elena, my dear sister Diana Carolina, and my lovely aunt Margarita. But mostly I would like to dedicate this dissertation to my grandmother Alicia who has always been there for me, has always accompanied me in the most important moments of my life, and has always inspired me to do my best, thank you for believing in me the way you have. I could not have done this if it were not for all of your support and belief in me. Again, thank you.

Me gustaría dedicarle este trabajo a mi maravillosa y amada esposa, y mejor amiga Paola, mis asombrosos padres José Reinaldo y María Elena, mi querida hermana Diana Carolina, y mi adorada tía Margarita. Pero más aún, me gustaría dedicarle esta tesis a mi abuela Alicia quien ha siempre estado ahí para mí, siempre me ha acompañado en los momentos más importantes de mi vida, y siempre me ha inspirado a dar lo mejor de mí, gracias abue por creer en mí como siempre has creído. No hubiese podido haber hecho esto si no contara con todo su apoyo y fe en mí. De nuevo, Gracias. 


\section{ACKNOWLEDGEMENTS}

I would like to thank all of my committee members for allowing me to work and complete this dissertation successfully from a far, and for their wisdom and support, I could not have done it without you. I would like to thank my friends and family that have always supported me, not only throughout my doctorate but throughout my academic life since the beginning. I would also like to thank all the people that made it possible for me to come to the United States, and complete my academic career successfully, it meant a lot and provided me with a once in a lifetime experience.

I would also like to thank my family, who supported the idea of going overseas, and have never, not once, made me feel guilty for pursuing my future and my dreams. I would like to thank my wife, whom I met at West Virginia University, and who has provided nothing but unconditional support along the way. And last but certainly not least, I would like to express my enormous gratitude to Dr. Barbara McFall, who was the one that not only allowed me to start my doctorate, but also supported my efforts unconditionally, and helped me to complete my dissertation and my doctorate successfully. There is no way I could have gotten through this process without her. Thank you all!

Me gustaría agradecerles a todos los miembros de mi comité por permitirme trabajar y completar esta tesis exitosamente a una gran distancia, por su sabiduría y apoyo, no podría haberlo hecho sin ustedes. Me gustaría agradecerles a todos mis amigos y mi familia, los cuales me han apoyado siempre, no solo en mi doctorado, pero a través de mi vida académica desde el inicio. También me gustaría agradecerle a 
toda la gente que hizo que fuera posible para mí venir a los Estados Unidos, y completar my carrera académica exitosamente, ha significado mucho para mí y me dio una experiencia única.

También me gustaría agradecerle a mi familia, que apoyó la idea de irme al exterior, y nunca, ni una vez, me han hecho sentir culpable por perseguir mi futuro y mis sueños. Me gustaría agradecerle a mi esposa, a quien conocí en West Virginia University, y quien me ha dado siempre un apoyo incondicional a través de este proceso. Y por último, me gustaría expresar mi enorme gratitud hacia la Dra. Barbara McFall, quien fue la que no solo me permitió comenzar mi doctorado, pero también apoyo mis esfuerzos incondicionalmente, y me ayudo a completar mi tesis y mi doctorado exitosamente, no hay forma de que pudiera haber pasado este proceso sin ella. ¡Gracias a todos! 


\section{TABLE OF CONTENTS}

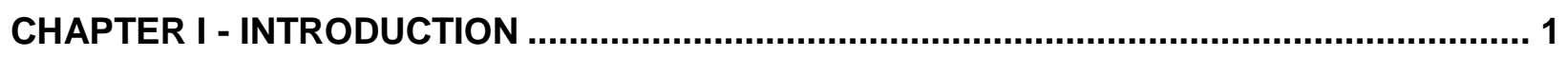

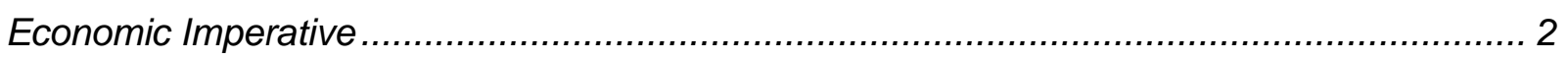

Latino Concentration by Location and Industry ......................................................... 4

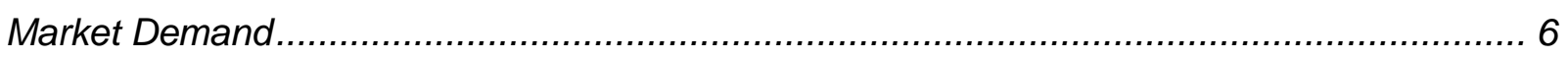

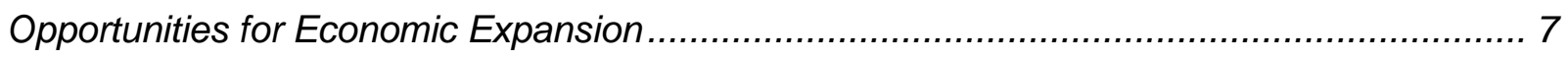

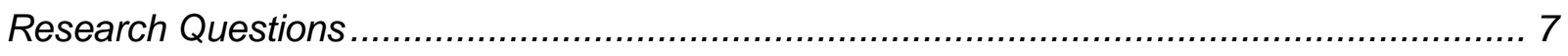

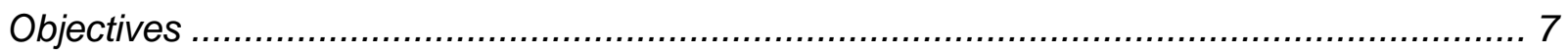

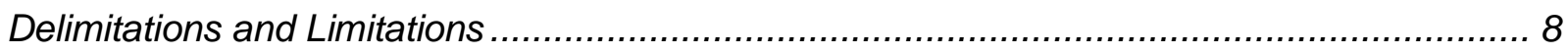

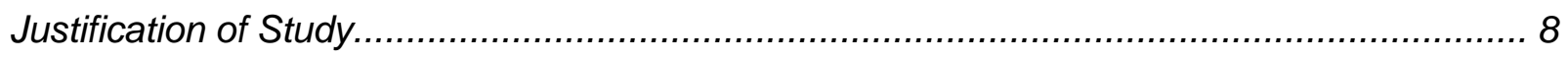

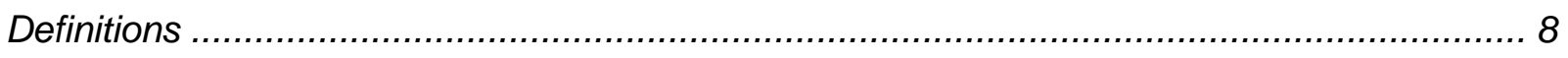

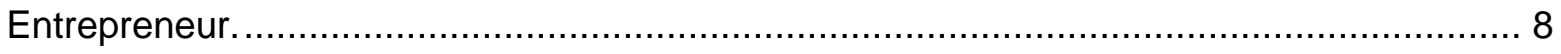

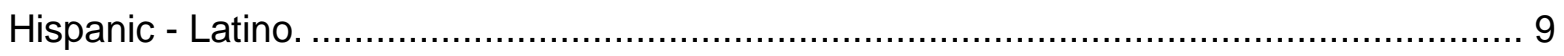

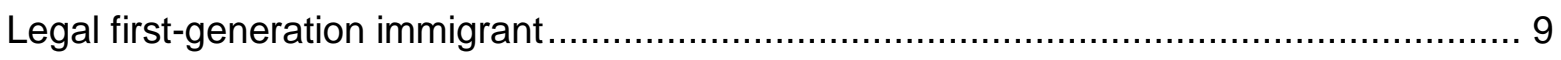

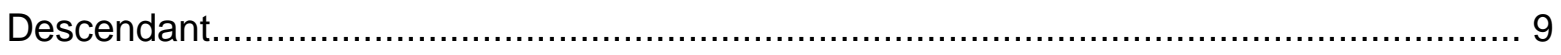

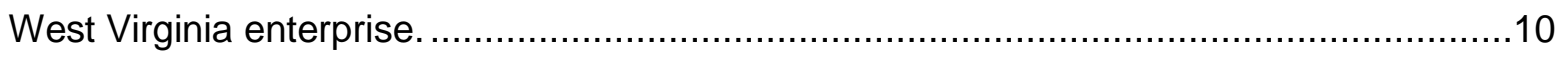

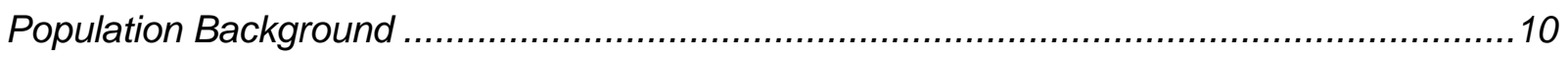

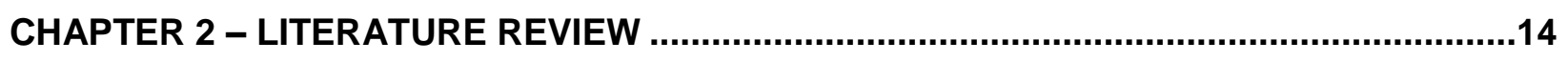

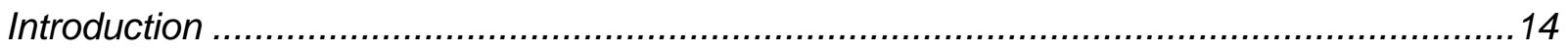

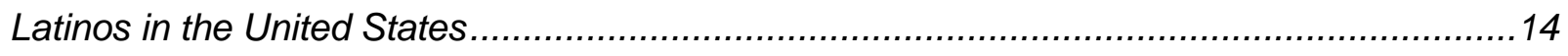

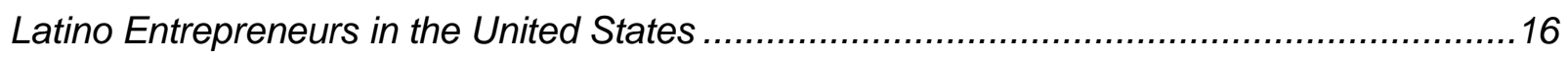

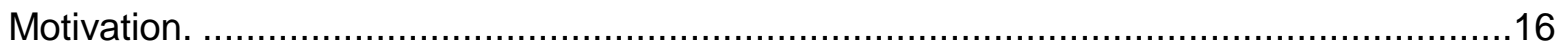

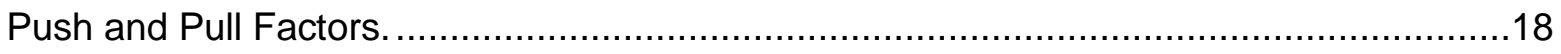

Contrasting Diverse Experience through PRSM Modeling ..............................................20

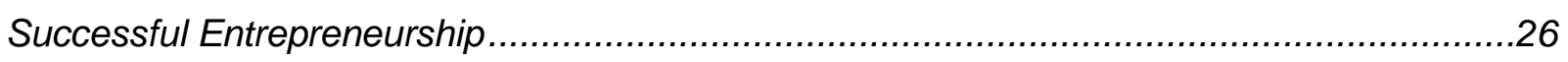




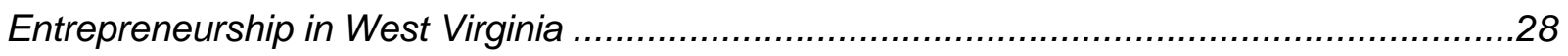

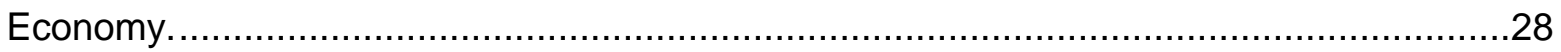

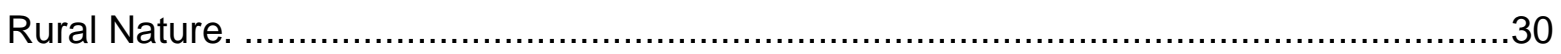

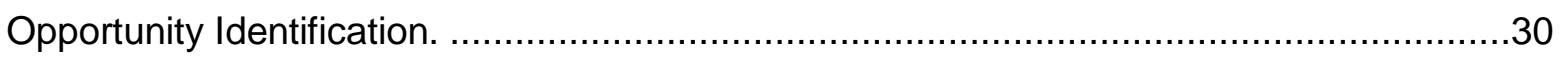

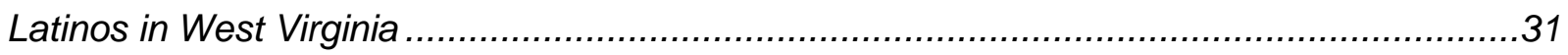

Difficulties for Latinos in West Virginia. .......................................................................

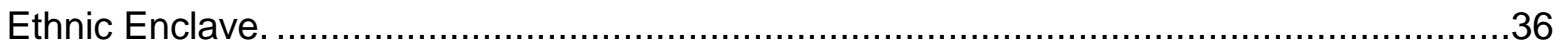

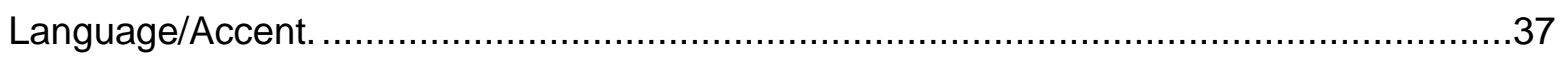

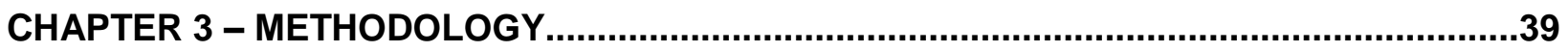

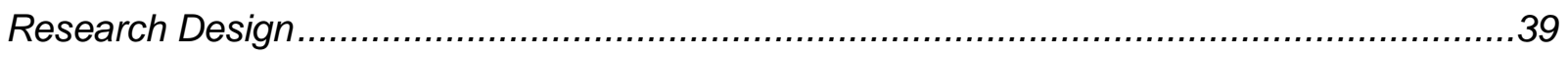

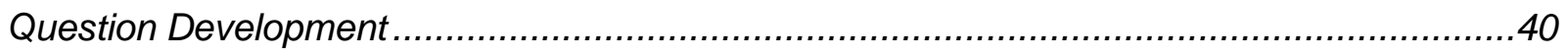

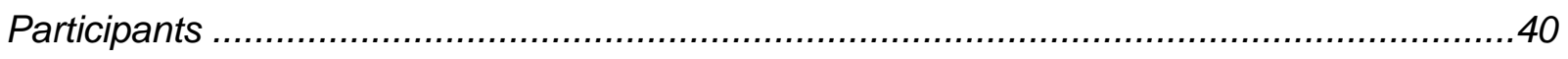

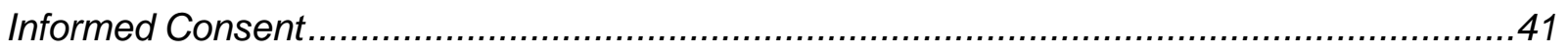

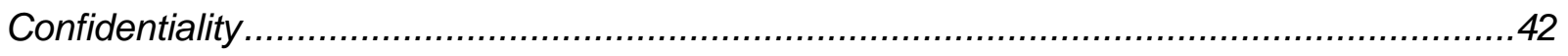

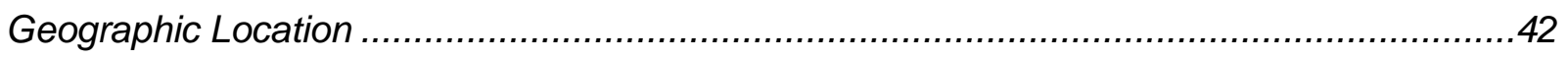

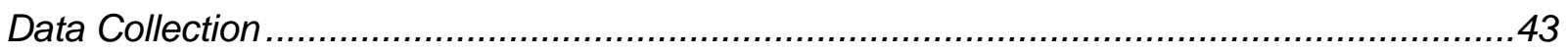

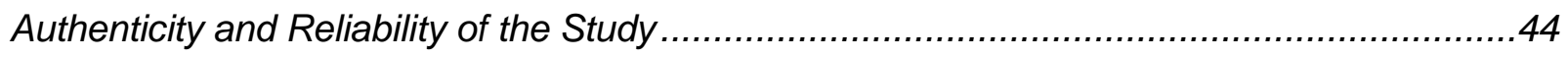

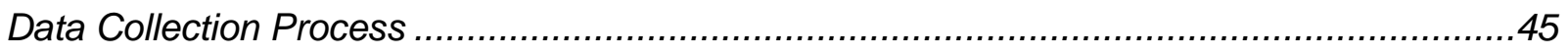

Timeframe

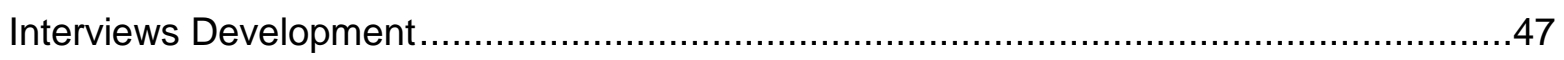

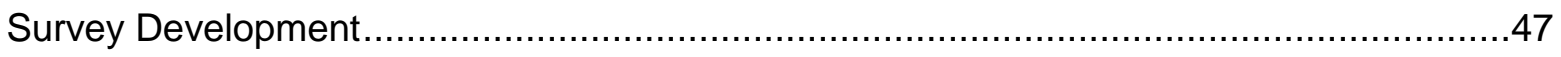

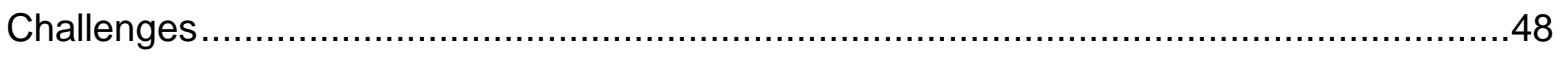

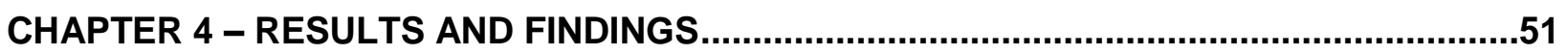

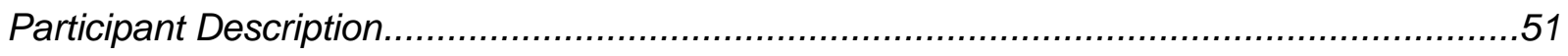

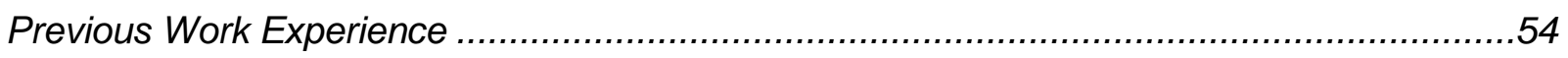




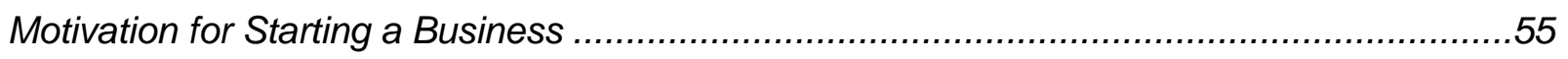

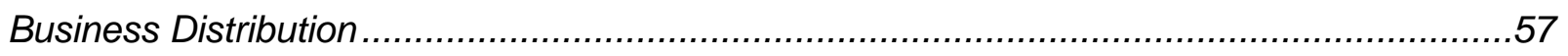

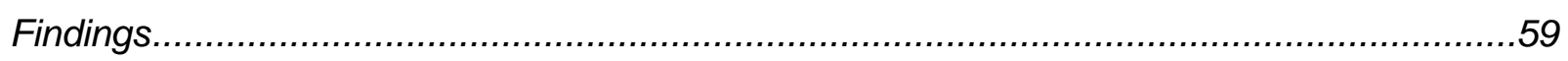

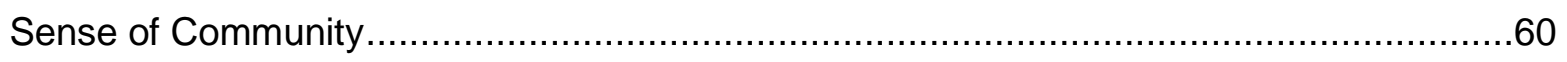

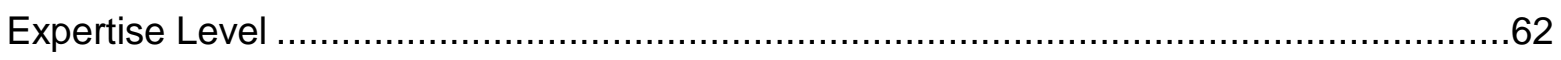

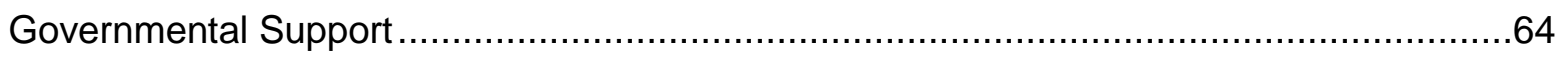

Trust Issues - Discrimination (Perception) ……………..........................................65

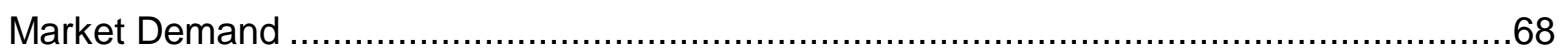

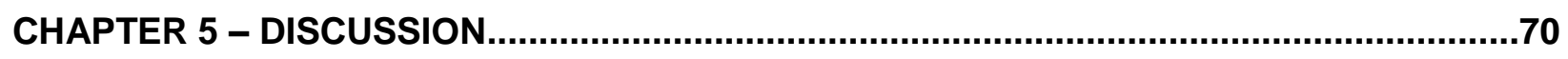

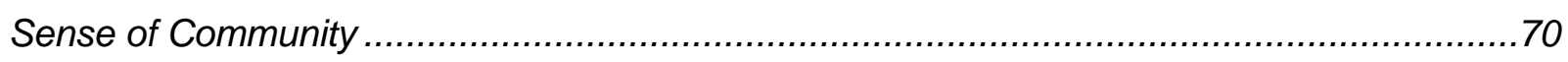

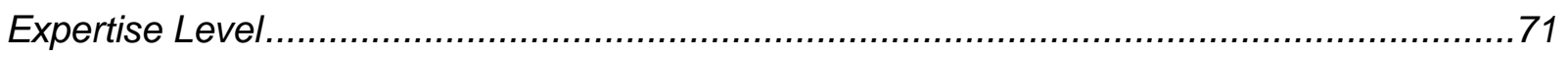

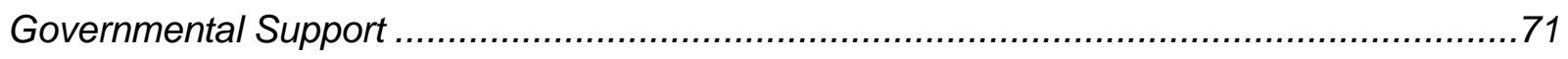

Trust Issues - Discrimination (Perception) …………............................................... 72

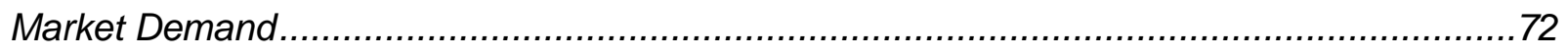

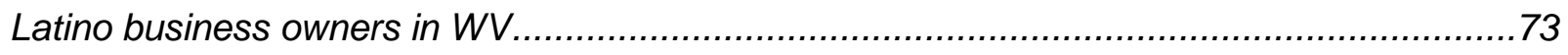

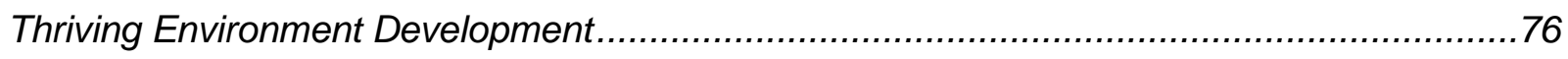

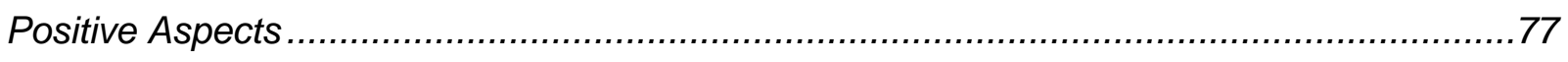

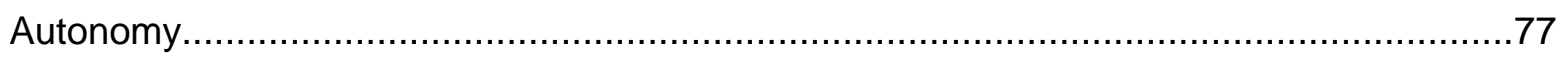

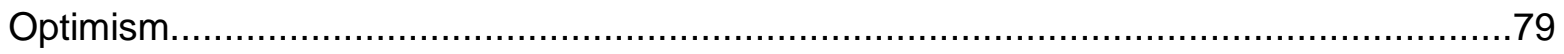

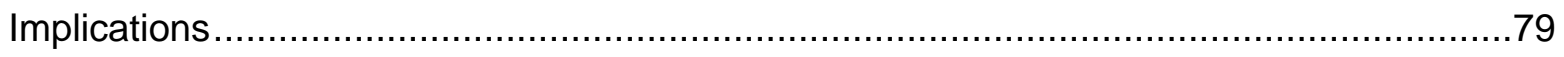

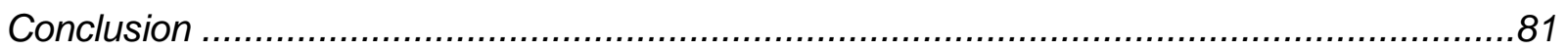

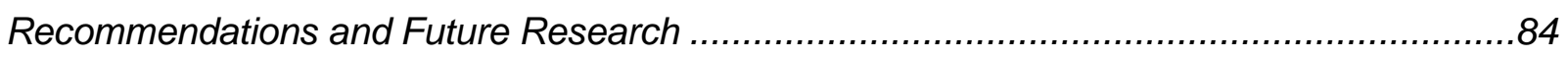

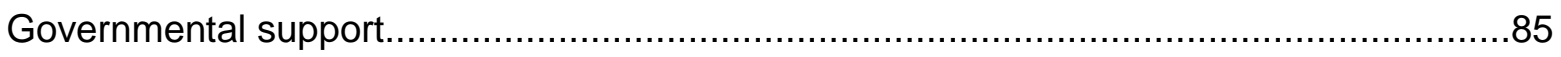

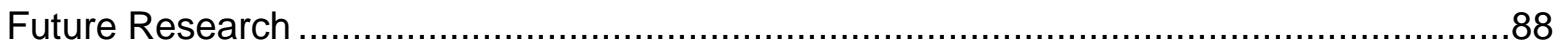

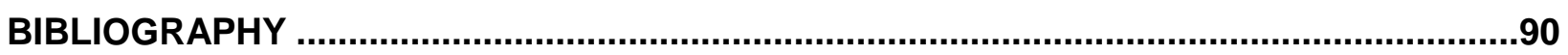




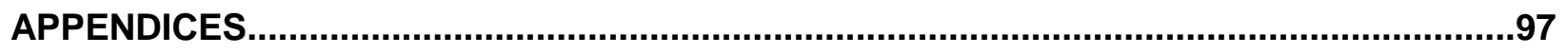




\section{LIST OF TABLES}

Table 1- Prior studies of Latino entrepreneurship.................................................. 1

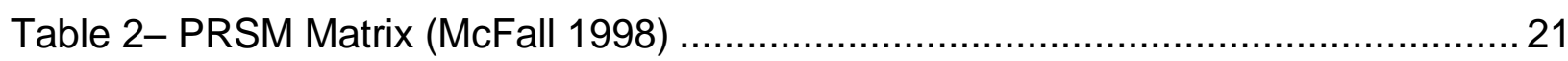

Table 3 - Resource Categorization in PRSM (McFall 2009) ..................................... 22

Table 4- Concise comparison of Latino and majority entrepreneurs (Environmental

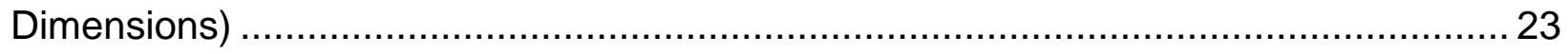

Table 5 - Concise comparison of Latino sub-groups and all entrepreneurs (Personal

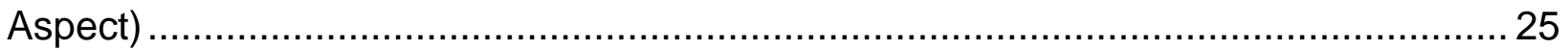

Table 6 - Historic analysis of entrepreneurship (Samli 2009) …................................ 27

Table 7- Critical personal traits of entrepreneurs (Samli 2009) …............................2 27

Table 8 - Graphic distribution of the percentage change experiences by all 50 states..34

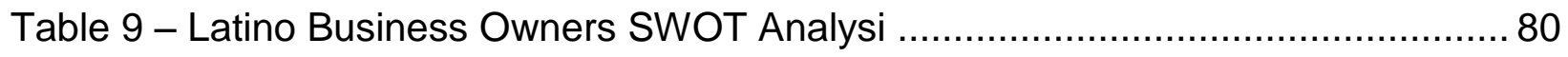

Table 10 - Demographic Profile of Participants ...................................................... 53

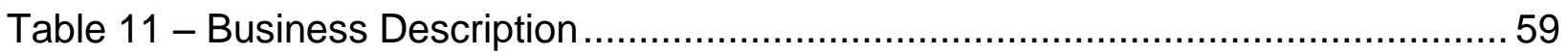




\section{LIST OF FIGURES}

Figure 1. Total Firms - Latino Owned Firms Growth Comparison (U.S Census Survey of

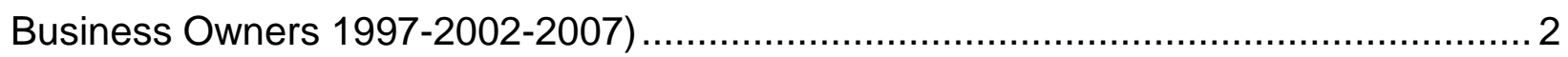

Figure 2. Percentage of Latino Businesses Concentration in Three Major States .......... 4

Figure 3. Hispanic Owned firms divided into industry. (U.S Census Bureau, 2010) ........5

Figure 4. Percent distribution of highly Hispanic populated states. (U.S Census Bureau 2010)

Figure 5. Percent Distribution of the Hispanic Population by Type of Origin: 2010 (U.S

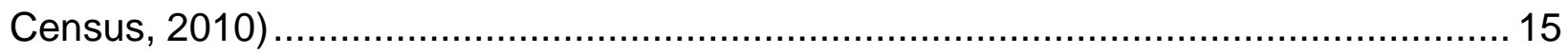

Figure 6. Personal Resource Systems Model. (c) B. McFall, 1998.............................. 20

Figure 8. 2006 Latino Occupation (U.S Census Bureau) ......................................... 32

Figure 7. 1980 Latino Occupation (U.S Census Bureau) …...................................... 32

Figure 9. State Percent Change 2000-2006 (U.S Census Bureau) ............................. 33

Figure 10. West Virginia Map depicting Morgan, Berkeley and Jefferson counties. (FRIS

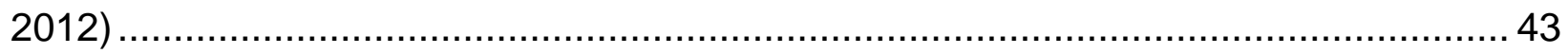

Figure 11. Latino Thriving Environment. Arcila (2013) ............................................... 76

Figure 12 - Entrepreneurial Issues Identified by Latinos in W.V............................... 83 
"It's going to be impossible to think about the future of the U.S. without thinking about Hispanics" Leo F. Estrada, UCLA 


\section{CHAPTER I - INTRODUCTION}

\section{Introduction}

The goal of this research study was to explore and understand why there are so few Latino Entrepreneurs in West Virginia, and to discover the entrepreneurial issues identified by Latino business owners in the state. Prior studies have examined entrepreneurship in a variety of settings in which Latinos are a significant population (see table 1). Some of the barriers to successful Latino entrepreneurship identified in Table 1 include financial funding, racial issues, ethnic enclaves, and getting along with people from other cultures. As in Smith's (2010) study, West Virginia is considered a non-traditional immigration destination. In fact, West Virginia ranks last in Latino entrepreneurship as reported in the 2010 U.S. Census.

Table 1

Prior studies of Latino entrepreneurship

\begin{tabular}{|c|c|c|c|c|}
\hline Author & Year & $\underline{\text { Title }}$ & Findings & Future Research \\
\hline Stewart, A.R. & 2011 & $\begin{array}{l}\text { Ethnic Entrepreneurship } \\
\text { and Latino Placemaking } \\
\text { in Suburban } \\
\text { Washington: The Case } \\
\text { of Langley Park, } \\
\text { Maryland }\end{array}$ & $\begin{array}{l}\text { Importance of ethnic enclave } \\
\text { Sociocommerscapes } \\
\text { Ethnic Communities Pg. } 118\end{array}$ & $\begin{array}{l}\text { Focus on } \\
\text { sociocommerscape. } \\
\text { Needs of local residents } \\
\text { need to be taken into } \\
\text { consideration }\end{array}$ \\
\hline Mendoza, C.M & 2007 & $\begin{array}{l}\text { Hispanic Entrepreneurs } \\
\text { Overcoming The Odds } \\
\text { Of Failure: A } \\
\text { Phenomenological } \\
\text { Study Of Latino } \\
\text { Business Owners }\end{array}$ & $\begin{array}{l}\text { Challenges: discrimination, legal } \\
\text { and financial issues pg. } 71 \\
\text { Family businesses were a trend, } \\
\text { importance of family } \\
\text { Autonomy } \\
\text { Importance of good service }\end{array}$ & $\begin{array}{l}\text { Latino business } \\
\text { development programs } \\
\text { Mentor programs } \\
\text { Latino children } \\
\text { development programs }\end{array}$ \\
\hline Smith, R.A & 2010 & $\begin{array}{l}\text { Latino Entrepreneurs In } \\
\text { Nontraditional } \\
\text { Destinations: } \\
\text { The Case Of Northern } \\
\text { Utah }\end{array}$ & $\begin{array}{l}\text { More likely to be married } \\
\text { Previous experience existed } \\
\text { Savings used for funding, no } \\
\text { banks or other financial sources } \\
\text { Most difficult aspect was } \\
\text { financial, challenges getting } \\
\text { loans } \\
\text { Relationships with customers and } \\
\text { suppliers, an issue }\end{array}$ & $\begin{array}{l}\text { Follow up interviews } \\
\text { *Replicate this study in } \\
\text { other non-traditional } \\
\text { destinations" }\end{array}$ \\
\hline Zarrugh, L.H & 2007 & $\begin{array}{l}\text { From Workers to } \\
\text { Owners: Latino } \\
\text { Entrepreneurs in } \\
\text { Harrisonburg, Virginia }\end{array}$ & $\begin{array}{l}\text { Alternative to bad economy, } \\
\text { Autonomy, Lack of capital and } \\
\text { competition highest barriers, } \\
\text { Rural Latino entrepreneurship } \\
\text { Poultry plant allure for Latinos }\end{array}$ & $\begin{array}{l}\text { Expand studies in rural } \\
\text { areas, How expansion in } \\
\text { low-wage employment } \\
\text { increases Latino } \\
\text { immigration }\end{array}$ \\
\hline
\end{tabular}


The intent of this study was to use these prior studies, further literature review, and personal interviews/surveys to explore the barriers that exist for Latino entrepreneurs in West Virginia and to develop first thoughts on how those perceived barriers might be addressed by products and services to attract Latino business owners to West Virginia and support their sustained success.

\section{Economic Imperative}

Nationwide, there were 2.3 million Latino-owned businesses reported in 2007, up 43.6\% from 2002. Receipts of total sales for these businesses were $\$ 345.2$ billion, up 55.5\% from 2002 (U.S Census Bureau, 2007). This represents a small, but growing segment of the economy (see Figure 1).

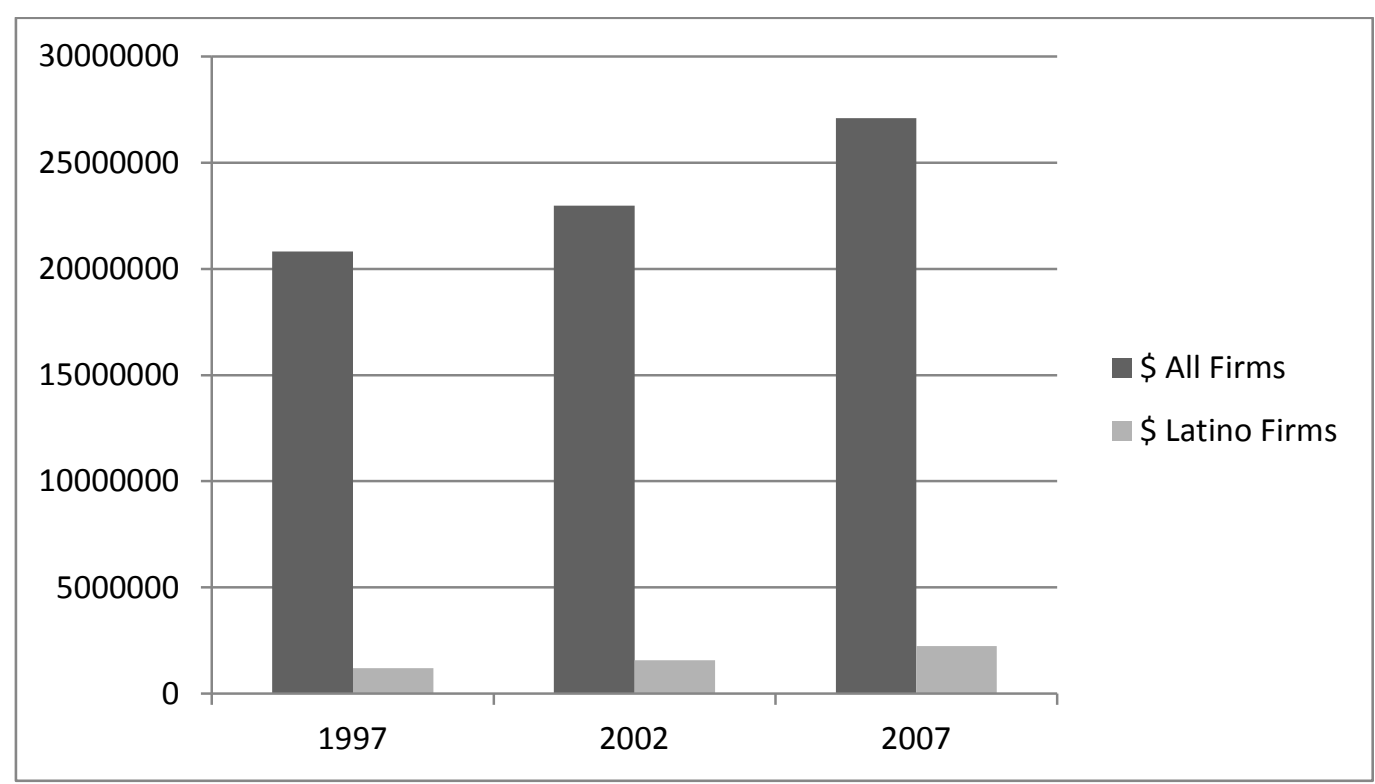

Figure 1. Total Firms - Latino Owned Firms Growth Comparison (U.S Census Survey of Business Owners 1997-2002-2007) 
On average, each Latino business totaled \$150,086.96 receipts in sales in 2007. Between 1997 and 2002 the total number of firms in the U.S increased by $10.34 \%$ while Latino owned businesses grew by 31.13\%. And between 2002 and 2007 the growth continued as Latino owned businesses increased by $42.91 \%$ as opposed to the $17.93 \%$ growth rate of all firms in the United States. The 2007 data is the latest available as the Survey of Business Owners conducted is conducted every five years by the U.S Census Bureau. Since 2008, growth of all segments has been impacted by the recession.

Latino owned businesses in the United States grew by 81 percent between 1982 and 1987 , from 232,044 to 420,000 firms, mostly due to the huge impact that Cuban immigrants had on the economy (Gale Learning, 2003). Even though the percentage rates have declined in recent years, due in part because of the much larger population, the U.S Census Bureau still found that "the number of Hispanic-owned businesses in the United States increased by $43.7 \%$ to 2.3 million, more than twice the national rate of 18.0\% between 2002 and 2007" (U.S Census Bureau, 2010, p. 2). In terms of numbers, Latino/Hispanic owned businesses rose from 232,044 in 1982 to 2.3 million in 2007, which is a growth of nearly 1000 percent in 15 years.

This rate of growth over such short period of time demonstrates the importance of Latino entrepreneurship in the United States and the economic influence that these businesses can have. Not only are Latino businesses growing in numbers, but they also seem to be growing financially as "Hispanic-owned businesses generated $\$ 345.2$ billion in sales in 2007, up 55.5 percent compared with 2002" and "the number of Hispanicowned businesses with receipts of $\$ 1$ million or more increased $51.6 \%$ - from 29,168 to 44,206 businesses between 2002 and 2007" (U.S Census Bureau, 2010 p. 3). These 
are impressive numbers for any demographic, that in this context provide additional reason to look at Latino entrepreneurship as a critical aspect of the United States' economy.

\section{Latino Concentration by Location and Industry}

In three states and three industries, Latino entrepreneurship has been much more significant. In those three states, New Mexico, Florida, and Texas, Latino businesses represented more than $20 \%$ of all business activity (U.S Census Bureau, 2010) (See figure 2).

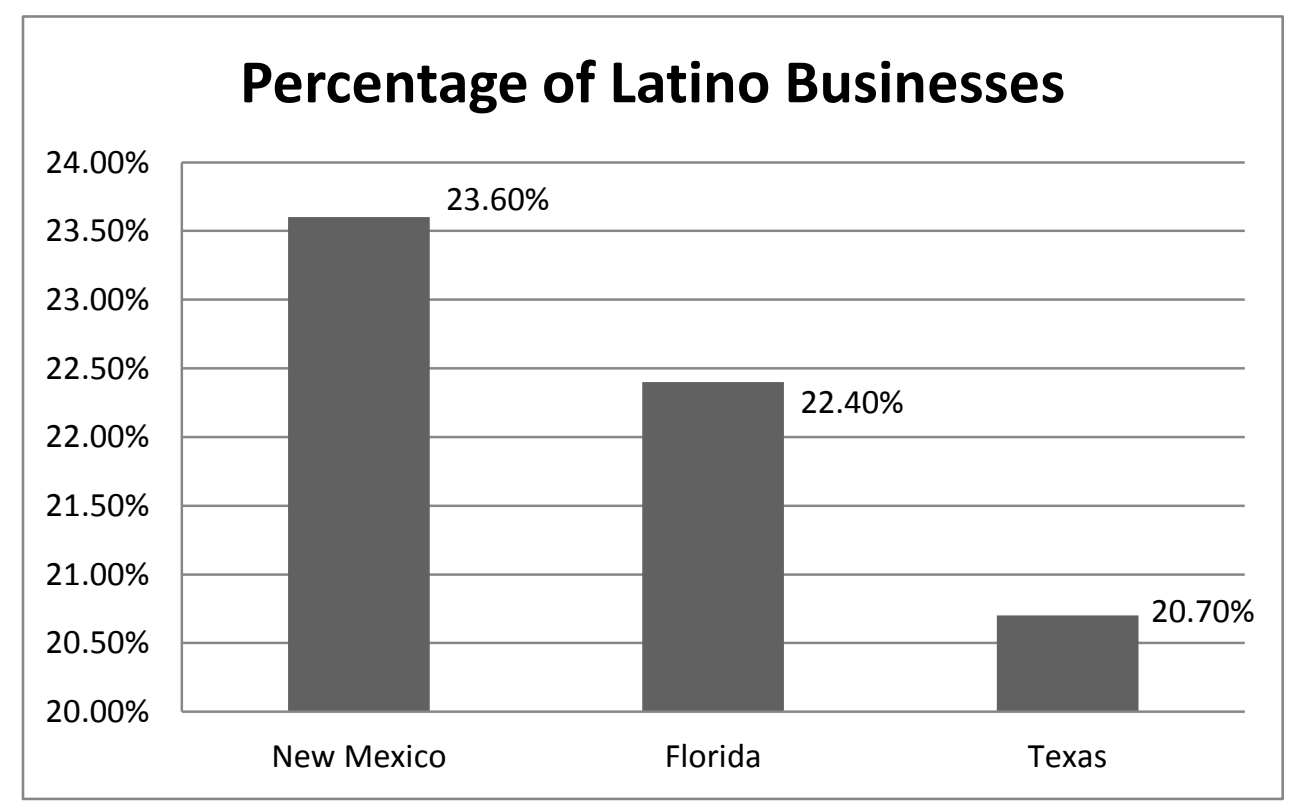

Figure 2. Percentage of Latino Businesses Concentration in Three Major States

Thirty percent of Hispanic-owned businesses reported were in construction, repair and maintenance, and personal and laundry services, and most of this activity was confined to three states with a high Latino population. According to the Survey of 
Business Owners by the United States Census Bureau "In 2007, 30.0\% of Hispanicowned U.S. firms operated in construction (NAICS 23) and repair, maintenance, personal, and laundry services (NAICS 81) sectors" and "Hispanic-owned U.S. firms accounted for $10.4 \%$ of all U.S. businesses in these sectors" (U.S Census Bureau, 2007, p. 4). Figure 3 provides a representation of the way Latino businesses are distributed.

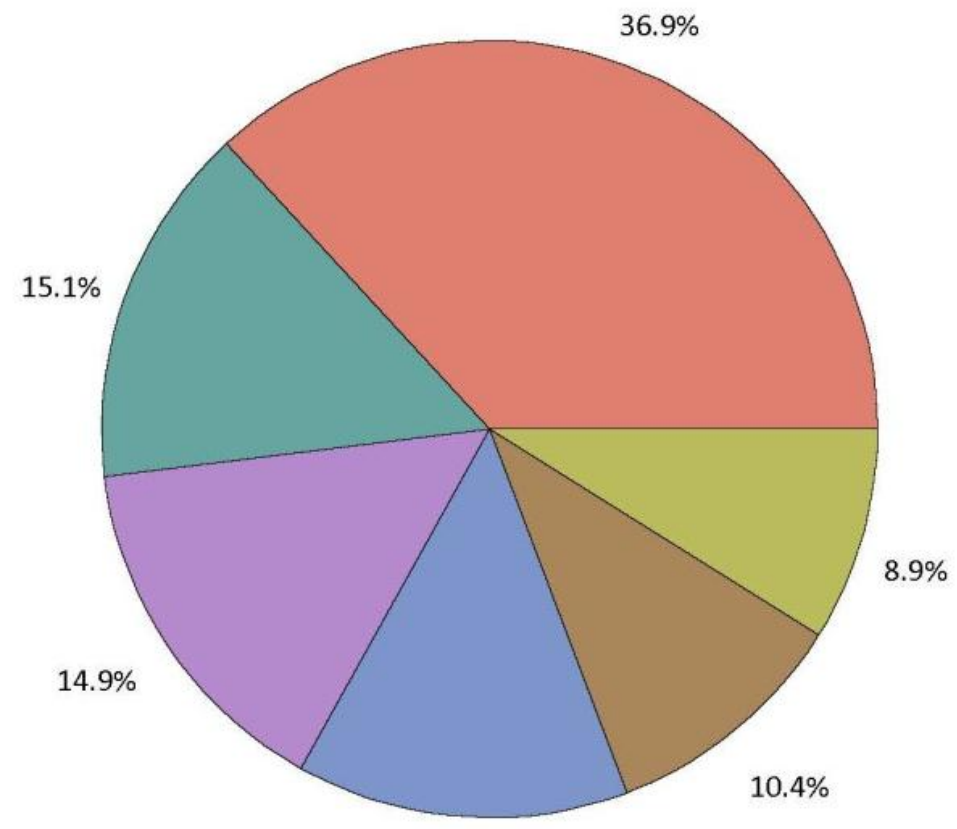

$13.9 \%$

NAICS Sectors $\square$ Administrative and support and waste management and remediation services $\square$ All other industries

$\square$ Construction

$\square$ Health care and social assistance

$\square$ Repair and maintenance, and personal and laundry services

$\square$ Transportation and warehousing

Figure 3. Hispanic Owned firms divided into industry. (U.S Census Bureau, 2010) 


\section{Market Demand}

Latino-owned businesses are not necessarily confined to the Latino market, but key segments do tend to be culturally biased and thus require a favorable market. The largest current segment, representing $36.9 \%$ of all other industries, includes the restaurant and grocery store industries. Demand for ethnic cuisine would generally be higher in more diverse, urban markets. The scarcity of Latinos in West Virginia is one of the major reasons why there are very few Latino businesses in the state. According to the 2010 United States Census Bureau QuickFacts, as of 2007 only $0.7 \%$ of the total firms in the state were owned by Latinos or Hispanics (U.S Census, 2010). Of that total, the 120,381 firms in West Virginia in 2007 yielded a mere 84 Latino owned businesses in the state.

The number of Latino businesses in West Virginia is very low compared to other regions. Adjacent Washington D.C, Baltimore, and Northern Virginia, however, are becoming crowded with Latino businesses becoming geographically saturated resulting in a hyper=competitive market dynamic. This may steer Latino businesses toward nearby but less competitive West Virginia. In fact, the population growth is already happening, in the eastern panhandle. Berkeley and Jefferson counties now account for $29 \%$ of the state's Hispanic population (Fox News Latino, 2012). According to this Fox News Article, there are "20 Hispanic-owned businesses in the Eastern Panhandle and half of them are in Martinsburg" (2012, p. 5). In this "Least Latino State" in the country, there is some hope for Latinos after all. 


\section{Opportunities for Economic Expansion}

West Virginia has the lowest number of Latino immigrants out of any state in the United States. Using the National average of receipts at 2007 values, an increase in Latino business activity of $20 \%$ (from 84 to 100 firms), would contribute around $\$ 2.4$ million dollars to the economy of West Virginia. Historically, business growth is achieved by:

1. Increasing market share in an existing segment,

2. Developing market share in a new segment, or

3. Developing a new segment in a new market.

West Virginia offers opportunity for improvement in all segments.

\section{Research Questions}

This research examined the factors involved in attracting and supporting Latino entrepreneurs starting and growing businesses in West Virginia by addressing the following research questions:

- Why are there so few Latino Entrepreneurs in West Virginia?

- What are the entrepreneurial issues identified by Latino business owners in West Virginia?

\section{Objectives}

This research was done with two main objectives in mind:

- To help potential Latino and non-Latino business owners in West Virginia to start their business more efficiently 
- Find out how to mitigate the issues and obstacles that are presented to Latino Entrepreneurs

The intent was to identify opportunities to attract additional Latino entrepreneurs to the state of West Virginia and retain them.

\section{Delimitations and Limitations}

This research was delimited to entrepreneurs who are legal first-generation Latino immigrants and their descendants operating West Virginia enterprises. The research was primarily qualitative with the expectation for findings limited to providing credible and useful information for application in the design of future projects involving this and similar populations in this and similar locations.

\section{Justification of Study}

The main justification for this study is the potential value it provides to the state of West Virginia, both socially and economically. In addition to setting groundwork in future research regarding minorities and entrepreneurship in the state.

\section{Definitions}

Entrepreneur. Entrepreneurship is defined as "any attempt to create a new business enterprise or to expand an existing business by an individual, a team of individuals, or an established business" (Zacharis, 2010, p. 3), and it has shown to be a critical aspect of the United States economy. Every year in the United States, entrepreneurs launch 850,000 new businesses. $11.3 \%$ of adult population in the U.S. is actively involved in trying to start a new business (Zimmerer, Scarborough, \& Wilson, 2010). Entrepreneurship is usually undertaken by people that have an "entrepreneurial 
spirit" which is defined by the ability of an individual to take risks in uncertain situations. According to Zimmerer, et al. (2010) the most significant economic development in recent history is the entrepreneurial spirit.

Hispanic - Latino. For the purposes of consistency, the terms Latino and Hispanic will be used interchangeably throughout this dissertation. This dissertation will utilize the definition of these terms provided by the United States Census Bureau, which states that:

The terms "Hispanic" or "Latino" refer to persons who trace their origin or descent to Mexico, Puerto Rico, Cuba, and Spanish speaking Central and South America countries, and other Spanish cultures. Origin can be considered as the heritage, nationality group, lineage, or country of the person or the person's parents or ancestors before their arrival in the United States. People who identify their origin as Hispanic or Latino may be of any race. (U.S Census Bureau, 2010, p. 1)

Legal first-generation immigrant. According to the U.S Census Bureau the term first generation refers to those who are foreign born. The second generation refers to those with at least one foreign-born parent. And the third-or-higher generation includes those with two U.S. native parents (U.S Census Bureau, 2012).

Descendant. According to the Merriam-Webster dictionary a descendant is "a person proceeding from an ancestor or source" (2012). 
West Virginia enterprise. An enterprise as defined by Merriam-Webster dictionary is a "unit of economic organization or activity; especially: a business organization" (2012). Therefore, when using the term West Virginia enterprise, this study refers to business organizations that have been initiated and/or are operated in the state of West Virginia.

\section{Population Background}

To date, Latino entrepreneurship research has mainly focused on those regions of the United States where Latino immigration is growing the fastest. Larger Latino populations makes it easier to analyze this phenomenon, however, researchers may have overlooked the impact, or lack thereof, of Latino entrepreneurs in regions in the United States where Latino immigration lags. This study focused on Latino entrepreneurship in West Virginia, a state where Latinos are "just over one percent of the state population, making it the state with the smallest Latino share in the entire country" (Llorente, 2011, p. 3).

The study of Latino entrepreneurship is critical to the United States as it is the fastest growing demographic in the country, and Latino businesses are growing at a rate that is more than double the national rate (U.S Census, 2010). Additionally, Latino entrepreneurship may potentially become a viable alternative for those individuals that are looking to obtain a better social and economic status, as an alternative to low paying labor jobs. Latino businesses can also aid in the diversifying of the state of West Virginia, to become more competitive in such a global economy. Several studies state that Latino immigrants, as workers, owners and consumers, are important assets to the 
communities in which they live (Hernández-León \& Zúñiga 2000; Saenz 2004; Zarrugh 2007).

Even though there are 2.3 million Latino businesses in the United States, and an estimated 50.5 million Latino or Hispanic individuals in the country, more than threequarters of these individuals live in the West or South of the country (U.S Census Bureau, 2010). Latinos, and therefore their businesses, have been, for the most part, concentrated in a few particular areas in the United States, and are not necessarily as widespread across the country See figure 4 .

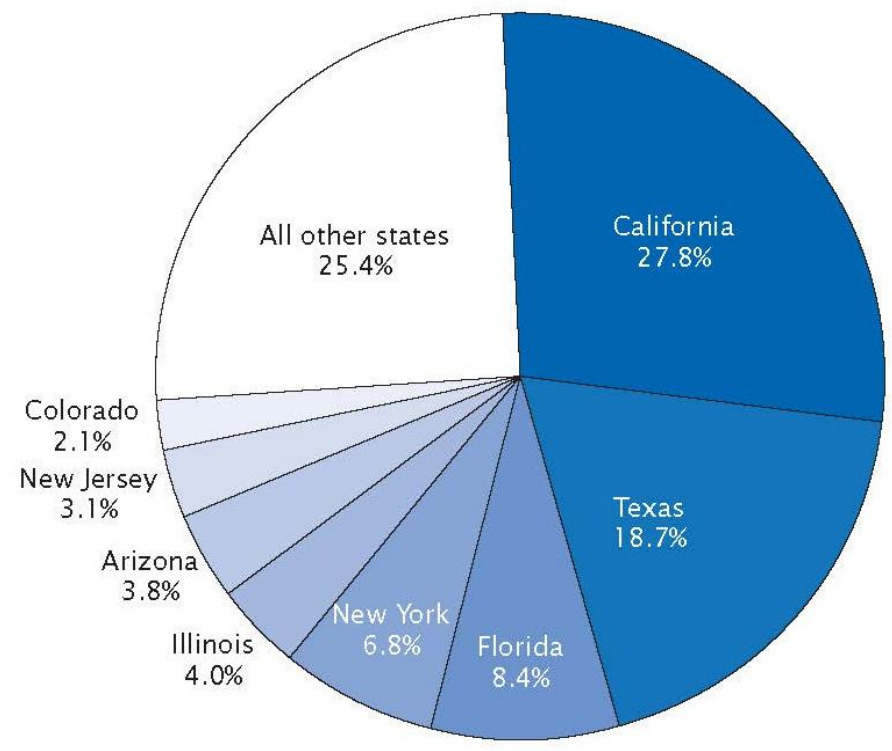

Source: U.S. Census Bureau, 2010 Census Summary File 1.

Figure 4. Percent distribution of highly Hispanic populated states. (U.S Census Bureau 2010)

According to the United States Census Bureau 2010 Hispanic Population brief, "over half of the Hispanic population in the United States resided in just three states: 
California, Texas, and Florida" (2010, p. 27). And to further demonstrate the extent of the concentration of the Latino population in the United States, $75 \%$ of Hispanics, or 37.6 million individuals in the country live in the following eight states: California, Texas, Florida, New York, Illinois, Arizona, New Jersey, and Colorado (U.S Census Bureau, 2010).

Therefore even though the growth of Latino small business ownership and the Latino population overall, has been staggering over these last two decades, it has not been a very uniform expansion across the country. The Hispanic or Latino Population for the United States, Regions, and States, and for Puerto Rico: 2000 and 2010 (U.S Census Bureau, 2010) in Appendix 1, shows that as of the year 2000 there were only three states where Latinos did not represent at least one percent of the population: Maine $(0.7 \%)$, Vermont $(0.9 \%)$, and West Virginia (0.7\%). By the year 2010, these percentages have increased to $1.3 \%, 1.5 \%$, and $1.2 \%$ respectively. West Virginia remains the state with the fewest Latinos per capita in the country.

More importantly, especially to a state like West Virginia, Latino entrepreneurs can potentially be used as liaisons or magnets that can attract others to move to the state which would increase this demographics' population in West Virginia. Latinos continue to move towards states like California, Florida, Texas, and New York not because they are closer to home or because they have easier access to those states, but because there is a larger ethnic enclave in those states than others. Latinos tend to be attracted to places where Latinos are. They tend to cluster and create communities, which may be one of the reasons why the Latino population in West Virginia is not growing as fast as the national rate. (U.S Census Bureau, 2010) 
According to the Immigration Policy Center (2012), West Virginia has 22,268 Latinos, which accounts for $1.2 \%$ of the total population. However, this number represents a growth of $81.4 \%$ since the year 2000 and the number of cities that have at least 100 Latino residents more than doubled to 23, over the past ten years (Fox News Latino, 2012). This mini boom shows that the eastern panhandle of the state, more specifically Berkeley and Jefferson counties, have the largest concentration of Latinos in the state, accounting for 29 percent of the Latino population. Martinsburg is the city with the highest number of Latinos in the state with 1,069 , whereas Ranson has 538 , and Charles Town 473 Latinos. This "mini boom" may help the state become more diverse and attract more Latinos to the state, which would potentially increase the number of Latino entrepreneurs in West Virginia.

The lack of ethnic enclave in the state is only one of the potential reasons why there are few Latino entrepreneurs in West Virginia. Additional reasons for the lack of Latino businesses may include: lack of funding opportunities, lack of market demand, lack of diversity in the state, legal issues, and language fluency issues (Smith, 2010). The focus of this study however, was to ascertain the perceptions of current entrepreneurs are in regards to why there are so very few Latino businesses in West Virginia. 


\section{CHAPTER 2 - LITERATURE REVIEW}

\section{Introduction}

To further establish a context for this study, the following literature review includes relevant findings from the fields of economics, Latino entrepreneurship, and the state of West Virginia. Moving from general to local, this chapter examines: (1) the reported experience (personal and professional) of Latinos in the United States, (2) contrasting diverse experience through PRSM modeling, (3) entrepreneurship, (4) entrepreneurship in the state of West Virginia, (5) economic conditions in West Virginia, (6) the rural nature of the state (7) opportunities for entrepreneurs in West Virginia, (8) and Latinos in the state of West Virginia.

\section{Latinos in the United States}

According to the U.S Census there are currently 50.5 million Hispanic or Latino residents in the United States. That figure accounts for $16 \%$ of the population and represents a growth of $13 \%$ from the 35.3 million Hispanic residents in the year 2000 . More than half the growth in the total population of the country was due to the increase in the Hispanic population in the United States (U.S Census Bureau, 2010). Out of the 50.5 million Latinos in the country, 31.8 million are of Mexican origin, while Puerto Rican accounted for 4.6 million, and Cubans represented 1.78 million. Figure 5 demonstrates the distribution of the Hispanic population by geographic origin in 2010 (see figure 5). 


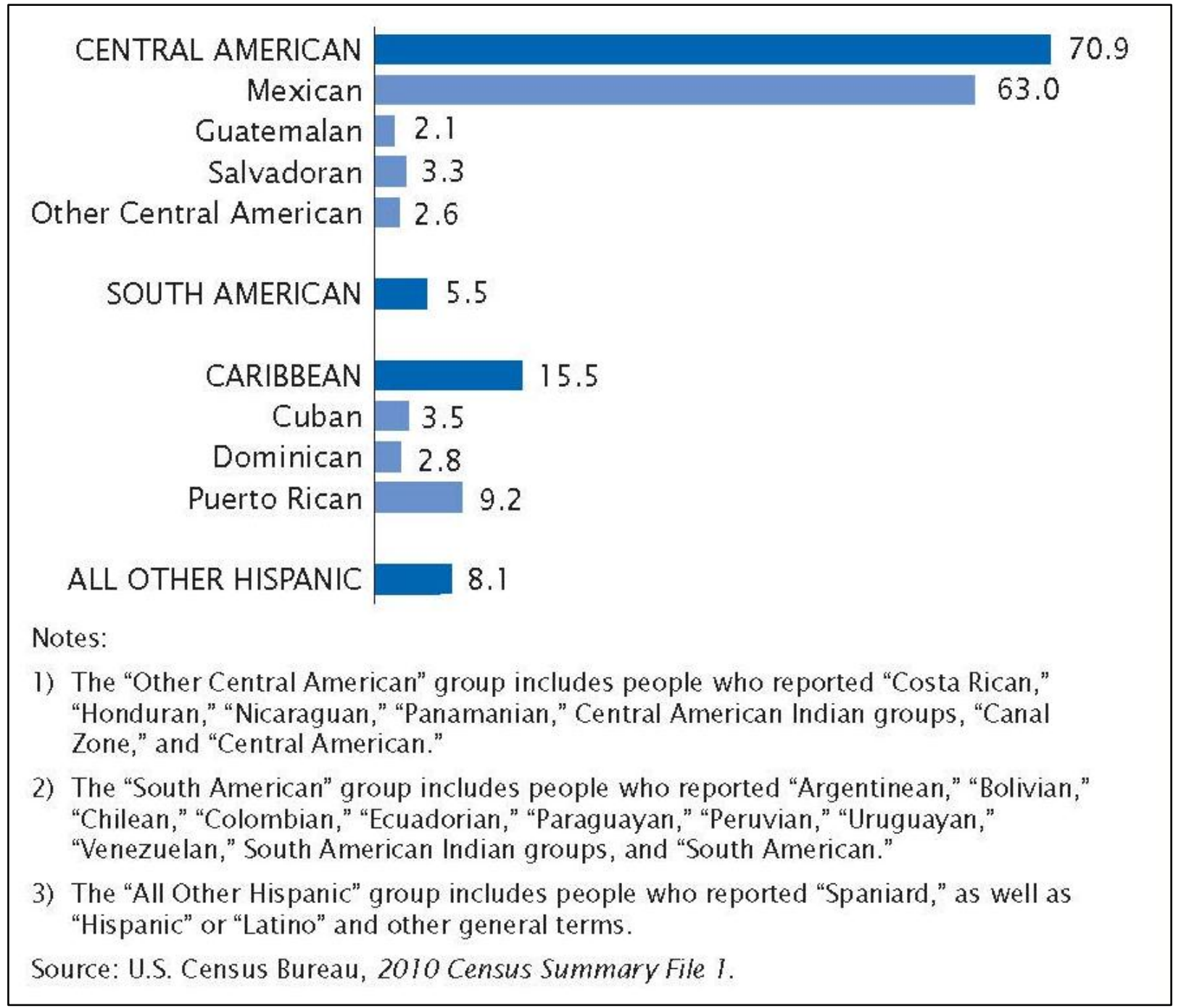

Figure 5. Percent Distribution of the Hispanic Population by Type of Origin: 2010 (U.S Census, 2010)

Of the 50.5 million Latinos in the United States, more than three-quarters lived in the West or South regions of the country (U.S Census Bureau, 2010). The Hispanic population grew in every region in the last ten years and it did so most significantly in the South and Midwest regions of the country. While the Hispanic population grew at a slower rate in the West and Northeast, significant growth still occurred between 2000 
and 2010 . The Hispanic population grew by $34 \%$ in the West, which was more than twice the growth of the total population in the West (14\%). The Northeast's Hispanic population grew by 33 percent- ten times the growth in the total population of the Northeast (3 percent) (U.S Census Bureau, 2010).

\section{Latino Entrepreneurs in the United States}

Motivation. Many studies suggest that a major reason immigrants become selfemployed and seek out entrepreneurial niches is that they are competitively disadvantaged with regard to both personal resources and high-value employment opportunities (Light \& Rosenstein, 1995; Waldinger, 1986; Wilson \& Portes, 1980). Additionally, the fact that only $26 \%$ of the minority business owners have a graduate degree, suggests that they are using self-employment as an alternative to lack of career opportunities (Enz, Marc, \& Catherine, 1993). Resource disadvantages can be seen as a lack of human and/or social capital such as subpar language skills, poor communicative skills, and/or lack of networking contacts that prohibit Latinos from competing successfully in the workforce. The labor-market may be experienced as discrimination in the workplace as a whole and/or lack of access to employment that pays well.

According to Spener and Bean (1999) two different theories are frequently referenced to explain the experience of Latino business owners. "Disadvantage Theory sees self-employment, at least in its origins, as deriving from economic deprivation and providing less in the way of economic benefits to immigrants than other forms of employment" (Spener \& Bean, 1999, p. 77). According to this theory, immigrant 
entrepreneurs would actually earn less money than their employed counterparts. This consequence is expected to result from individual level factors (i.e. age, gender, educational achievement, and language proficiency), as well as certain contextual factors (i.e. the unemployment rate and the size of the local construction sector relative to other sectors) which exert a greater influence in determining immigrant income. The second theory proposes that sizeable ethnic economies often provide immigrant and ethnic entrepreneurs' opportunities to expand their service or product markets, potentially generating even more success. Under this scenario, Latino entrepreneurs, at least on average, will earn more than other Latino workers, all else being equal.

Spener and Bean (1999) conclude that self-employment generates more income for co-ethnic wage and salary workers in cities where more people speak Spanish. Additionally, Wang \& Wei (2007) state that when it comes to immigrants in the U.S, selfemployment is generally related to better socio-economic conditions: for example, more work experience, earlier immigration to the United States, and higher job earnings. Motivationally speaking, immigrant entrepreneurs currently seem to be more influenced by the external environment around and the opportunities available rather than what they would like to do.

Bonacich (1987) found that immigrant entrepreneurs perceive starting their own business as a way of "Making It" in America. They see it as an opportunity to be the owners of their own destiny and a better way to get what they want. Another motivating factor for Latino entrepreneurs to start a business in the United States is that, selfemployment has been argued to be an important stepping stone for economic assimilation among immigrants, as it aids the entrepreneur to become more aware of 
the way society works. By owning a small business, Latino entrepreneurs are forced to learn to better interact with their American counterparts (Cummings, 1980). The entrepreneur has to learn to deal with customers, suppliers, government, and a number of different individuals and entities that obligate him or her to increase human capital.

Additionally, there are two different hypotheses regarding motivational perspectives of Latino business owners prior to opening their business. "Blocked mobility" claims that limited opportunities in the general labor market, including experiences with discrimination, lead to establishing a business. "Steppingstone", as claimed by Tienda and Raijman (2004), states that employment in a co-ethnic firm promotes entrepreneurial behavior by providing business-specific training and knowhow; furthermore, the study also identified unemployment as a potential reason for entrepreneurial disposition, which supports Spener and Bean's (1999) disadvantage theory.

Push and Pull Factors. Push and pull factors further describe the reason why Latinos start businesses in the United States. Push factors include factors that block opportunities to pursue wage and salary employment in the primary job market, forcing immigrants into self-employment as a way out of poverty (Shinnar \& Young, 2008). This phenomenon forces Latino immigrants to open up their own business because they see it as a much more viable option than competing in the primary workforce. This concept further supports Light's (1972) theory that Hispanics see entrepreneurship as a much better economic option causing them to get involved in entrepreneurial ventures.

According to the United States Bureau of Labor Statistics, the United States has an unemployment rate of $9.2 \%$. This unemployment rate creates a push factor that 
could potentially motivate Latinos to start their own business, as immigrants who tend to be excluded from the primary job market; entrepreneurship develops an alternative to this less desirable second market (Shinnar \& Young, 2008). Basically Latinos, and immigrants as a whole, are pushed to start their own business because they have no other choice. Even if they perceive the primary market to be more stable and full of opportunities, Latinos will be pushed to entrepreneurial activity whether they want it or not.

To further support push factors, Latino income in the United States has been greatly hindered due to the lack of English fluency. Yang states that "While the average income for the entire sample of California workers is $\$ 42,145$ per year the average income for all other ethnicities was $\$ 44,516$ and the average income for Latinos was $\$ 28,394$, a difference of $\$ 16,122 "$ (2005, p. 34). This discrepancy creates a motivating factor for Latinos to be more inclined to start their own businesses and be entrepreneurial as they perceive this option to be more profitable than trying to compete in the workforce.

Alternatively, pull factors are the positive motivation for Latinos and immigrants to start a business. This phenomenon presumes that entrepreneurial activity follows the promise of higher earnings; enhanced professional standing; a greater sense of independence; and a flexible schedule to accommodate family needs (Shinnar \& Young, 2008).

Although pull factors also appear to be a major factor in Latino entrepreneurship, human capital, such as age, education, language proficiency, work experience, and tenure acquired in the home country is often not transferable to the needs of the primary 
United States job market (Shinnar \& Young, 2008). Latinos, understanding the limits of their formal knowledge and human capital, soon realize that practical competencies and life experiences can be more easily applied to self-employment. For example, a professional carpenter in the home country may find it much easier to operate on his own rather than trying to convince a potential employer that he possess the skills to be a good carpenter. The push and pull factors are both motivating factors that have an impact on the reason why Latinos decide to open up a business in the United States.

\section{Contrasting Diverse Experience through PRSM Modeling}

A brief comparison of the behaviors and experience of Latino entrepreneurs and majority entrepreneurs in the United States highlights the contrasts. The Personal Resource Systems Model/Matrix offers a systemic format for examining such interactions. The human-centered model depicts interactions with the environment in six broad dimensions; intellectual, organizational, social, material, natural, and financial which are further illustrated in Figure 6 (PRSM; McFall, 1998).

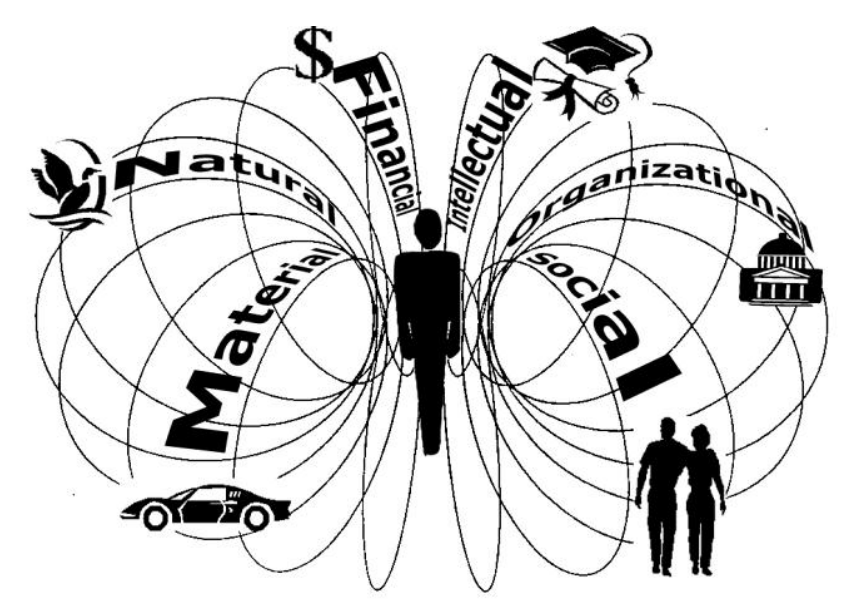

Figure 6. Personal Resource Systems Model. @ B. McFall, 1998. 
The central human engages his/her environment through three distinct personal aspects (mental, emotional, and physical). These interactions are reported in the PRSM matrix (Table 2).

Table 2

PRSM Matrix (McFall 1998)

\begin{tabular}{|l|l|l|l|l|}
\hline \multicolumn{1}{|c|}{ Mental } & Emotional & Physical & \\
\hline Intellectual & & & & $\begin{array}{l}\text { Intellectual } \\
\text { Satisfaction }\end{array}$ \\
\hline Organizational & & & & $\begin{array}{l}\text { Organizational } \\
\text { Satisfaction }\end{array}$ \\
\hline Social & & & & $\begin{array}{l}\text { Social } \\
\text { Satisfaction }\end{array}$ \\
\hline Material & & & & $\begin{array}{l}\text { Material } \\
\text { Satisfaction }\end{array}$ \\
\hline Natural & & & & $\begin{array}{l}\text { Natural } \\
\text { Satisfaction }\end{array}$ \\
\hline Financial & & & & $\begin{array}{l}\text { Financial } \\
\text { Satisfaction }\end{array}$ \\
\hline & & & & $\begin{array}{l}\text { Total } \\
\text { Quality of Life }\end{array}$ \\
\hline
\end{tabular}

In addition to offering a formal means of comparison, multiple matrices may be statistically accumulated over time and across populations to capture both individual histories and the longer-term experiences of broader communities. Specific definitions for each PRSM dimension are provided in Table 3 (see Table 3). 
Table 3

Resource Categorization in PRSM (McFall 2009)

\begin{tabular}{ll}
\hline Resource Category & Includes \\
\hline $\begin{array}{l}\text { Intellectual Resources } \\
\text { (maintain knowledge \& } \\
\text { advance learning) }\end{array}$ & $\begin{array}{l}\text { mastered bodies of knowledge, such as } \\
\text { language, math, history, and cultural } \\
\text { background; and accessible repositories of } \\
\text { knowledge including experts, books, } \\
\text { mentors, teachers, technology, media, etc. }\end{array}$ \\
\hline $\begin{array}{l}\text { Organizational Resources } \\
\text { (are organized around a }\end{array}$ & $\begin{array}{l}\text { businesses, schools, churches, government } \\
\text { entities, fraternal organizations, clubs, etc. }\end{array}$ \\
\hline $\begin{array}{l}\text { Social Resources } \\
\text { (entities who provide }\end{array}$ & $\begin{array}{l}\text { parents, siblings, spouse, partner, children, } \\
\text { and nurturance }\end{array}$ \\
$\begin{array}{l}\text { Material Resources } \\
\text { (human constructed goods } \\
\text { designed to leverage positive, } \\
\text { or ameliorate negative, } \\
\text { experiences) }\end{array}$ & pets, etc. \\
\hline $\begin{array}{l}\text { Natural Resources } \\
\text { (basic elements of temporal } \\
\text { experience) }\end{array}$ & $\begin{array}{l}\text { clothing, shelter, furnishings, transportation, } \\
\text { tools and equipment, toys, etc. }\end{array}$ \\
\hline $\begin{array}{l}\text { Fymancial Resources } \\
\text { of exchange) }\end{array}$ & money, credit cards, insurance, other \\
& negotiable assets, liabilities, capital, etc. \\
\hline
\end{tabular}

Table 4 offers a concise comparison of majority and Latino entrepreneurs experience within these environmental dimensions. The most important contrasts found in the environmental dimensions are the Intellectual, social, and financial dimensions. The differences in education, social and human capital, and barriers to access capital 
between the majority of entrepreneurs and Latino

entrepreneurs provide an insight into the different challenges that this particular

demographic has to face when starting a business.

Table 4

Concise comparison of Latino and majority entrepreneurs (Environmental Dimensions)

\begin{tabular}{|c|c|c|}
\hline & Majority Entrepreneurs & Latino Entrepreneurs \\
\hline Intellectual & $\begin{array}{l}\text { Of } 549 \text { American company founders } \\
\text { across a variety of industries, } 95.1 \% \text { of } \\
\text { respondents had earned bachelor's } \\
\text { degrees, and } 47 \% \text { had more advanced } \\
\text { degrees (Shah, } 2009, \text { p. } 1 \text { ). }\end{array}$ & $\begin{array}{l}\text { According to the United States } \\
\text { Department of Education, when it } \\
\text { comes to postsecondary education in } \\
2008 \text { only } 26 \% \text { of Hispanic } 18-24 \\
\text { years-olds were enrolled in a program } \\
\text { (Aud, Fox, \& KewalRamani, } 2012, \text { p. } 3 \text { ). } \\
\text { Additionally, the low level of education } \\
\text { attainment in Latin America makes it } \\
\text { more difficult for immigrants to become } \\
\text { successful entrepreneurs in the United } \\
\text { States. In Latin America, " } 14 \% \text { of adults } \\
26 \text { years and older cannot read or write } \\
\text { (Reimers, 1999, p. 16). }\end{array}$ \\
\hline Organizational & $\begin{array}{l}\text { The Council for Entrepreneurial } \\
\text { Development (CED) provides } \\
\text { education, mentoring and capital } \\
\text { formation resources to new and } \\
\text { existing high-growth entrepreneurs } \\
\text { through annual conferences, seminars, } \\
\text { workshops and programs on } \\
\text { entrepreneurial management and } \\
\text { finance (CED, 2010, p. 5) }\end{array}$ & $\begin{array}{l}\text { When asked about resources that were } \\
\text { most important, the most common } \\
\text { response was that there were no } \\
\text { resources available. Of the } 21 \\
\text { respondents that answered } \\
\text { this question, five of them felt that they } \\
\text { were on their own (Smith, 2010) } \\
\text { Agencies and organizations like the } \\
\text { Chamber of Commerce may not have } \\
\text { adapted to meet the needs of Latino } \\
\text { entrepreneurs (Smith, 2010) } \\
\text { Only two of the twelve entrepreneurs } \\
\text { that were interviewed were able to } \\
\text { identify a local organization that helped } \\
\text { them establish or maintain their } \\
\text { business. The rest of the entrepreneurs } \\
\text { claimed that they knew very little to } \\
\text { nothing about state and local } \\
\text { organizations that might assist them in } \\
\text { their entrepreneurial pursuits. (Smith, }\end{array}$ \\
\hline
\end{tabular}




\begin{tabular}{|c|c|c|}
\hline & & 2010) \\
\hline Social & $\begin{array}{l}\text { The literature on social capital } \\
\text { argues that social capital plays an } \\
\text { important role in a knowledge-driven } \\
\text { economy because it facilitates and } \\
\text { promotes economic actors' acquisition } \\
\text { of knowledge and useful information } \\
\text { (Doh \& Zolnik, 2011) } \\
\text { Through social networks, individuals } \\
\text { can access useful information and } \\
\text { knowledge and make decisions in } \\
\text { response to a given set of alternatives } \\
\text { based on acquired information and } \\
\text { (formal and/or tacit) knowledge (Doh \& } \\
\text { Zolnik, 2011) }\end{array}$ & $\begin{array}{l}\text { Among the things that social networks } \\
\text { provide them are: securing financial } \\
\text { capital, recruiting workers, accessing } \\
\text { clientele, securing locations and } \\
\text { equipment, advertising, and obtaining } \\
\text { information about licenses and permits } \\
\text { (Smith, 2010) } \\
\text { "about half ( } 48 \% \text { to } 49 \% \text { ) of Latino } \\
\text { immigrants who have come to the U.S. } \\
\text { in the last } 19 \text { years say that in the last } \\
12 \text { months, they have sent money to } \\
\text { someone living abroad -- a number that } \\
\text { holds remarkably steady whether they } \\
\text { have lived in the U.S. less than } 6 \text { years } \\
\text { or between } 13 \text { and } 19 \text { years" (Torres, } \\
\text { Pelham, \& Crabtree, } 2009, \text { p. } 13 \text { ) } \\
\text { "61 percent of people overall said } \\
\text { Hispanics face significant discrimination, } \\
\text { compared with } 52 \text { percent who said } \\
\text { blacks do and } 50 \text { percent who said } \\
\text { women" (Fram, } 2010, \text { p. } 2 \text { ). }\end{array}$ \\
\hline Material & $\begin{array}{l}\text { The majority of entrepreneurs rely on } \\
\text { their social network to gain access to } \\
\text { materials in a more affordable and } \\
\text { practical manner }\end{array}$ & $\begin{array}{l}\text { Non-Latino friends were most likely to } \\
\text { help with aspects like location, } \\
\text { equipment, and licenses and permits } \\
\text { (Smith, 2010) }\end{array}$ \\
\hline Natural & $\begin{array}{l}\text { The majority of Americans have } \\
\text { access to clean water and air } \\
\text { conditioning }\end{array}$ & $\begin{array}{l}\text { Many immigrants, documented or } \\
\text { undocumented, can't afford air } \\
\text { conditioning this year. Maricopa County } \\
\text { has already had nine deaths this year } \\
\text { due to the extensive heat (Perez, 2011) }\end{array}$ \\
\hline Financial & $\begin{array}{l}\text { The Small Business Association } \\
\text { watches out for small businesses in } \\
\text { America by helping them to stay in } \\
\text { business. They offer to help them find } \\
\text { educational training when needed, and } \\
\text { assist small business owners with } \\
\text { finding alternative funding sources } \\
\text { when they need it (SBA, 2011) } \\
\text { Federal, state and local governments } \\
\text { offer a wide range of financing } \\
\text { programs to help small businesses } \\
\text { start and grow their operations. These } \\
\text { programs include low-interest loans, } \\
\text { venture capital, and scientific and } \\
\text { economic development grants (SBA, } \\
\text { 2012) }\end{array}$ & $\begin{array}{l}\text { Latino entrepreneurs } \\
\text { in established destinations rely heavily } \\
\text { on co-ethnic networks to help finance } \\
\text { their } \\
\text { businesses (Light and Gold 2000; } \\
\text { Portes 1995; Waldinger et al. 1990) } \\
\text { In terms of business start-up, the typical } \\
\text { entrepreneur tends to lack access to } \\
\text { mainstream credit, which is for Latino } \\
\text { entrepreneurs in traditional destinations } \\
\text { (Smith, 2010) } \\
\text { Entrepreneurs in Cache Valley generally } \\
\text { acquired personal savings or property } \\
\text { by working in manufacturing or service } \\
\text { work, which they used to finance their } \\
\text { business. (Smith, 2010) }\end{array}$ \\
\hline
\end{tabular}


The personal aspects of the entrepreneur are likewise critical to his or her

potential success. Therefore it is important to contrast experience of the majority with

that of Latino entrepreneurs whose experience can be completely different. Table 5

offers a concise comparison of majority and Latino entrepreneurs' personal aspects

(see Table 5).

Table 5

Concise comparison of Latino sub-groups and all entrepreneurs (Personal Aspect)

\begin{tabular}{|c|c|c|}
\hline & All Entrepreneurs & Latino Entrepreneurs \\
\hline Mental & $\begin{array}{l}\text { Entrepreneurs think outside the } \\
\text { box } \\
\text { They are in business for more } \\
\text { than just money } \\
\text { They are not scared of failure, } \\
\text { they embrace it } \\
\text { They are mentally tough and } \\
\text { understand delayed gratification } \\
\text { They know who to listen to } \\
\text { (Asala, 2010) }\end{array}$ & $\begin{array}{l}\text { "Some Latino business owners in } \\
\text { Queens have accused their local } \\
\text { community board of } \\
\text { discriminating against them when } \\
\text { they applied for liquor licenses" } \\
\text { (Medina, 2012, p. 2) } \\
\text { Self-awareness: "While } 81 \\
\text { percent of Latinos said Hispanics } \\
\text { confront a lot or some } \\
\text { discrimination, a smaller but still } \\
\text { substantial } 59 \text { percent of non- } \\
\text { Hispanics said so" (Fram, 2010, } \\
\text { p. 5) }\end{array}$ \\
\hline Emotional & $\begin{array}{l}\text { Past research has suggested } \\
\text { that positive emotions may } \\
\text { enhance entrepreneurial } \\
\text { creativity, including opportunity } \\
\text { recognition (Baron, 2008) } \\
\text { Additionally, entrepreneurs who } \\
\text { display passion - positive, } \\
\text { intense feelings - about their } \\
\text { ventures tend to be more } \\
\text { successful than those who do not } \\
\text { display passion (Baum \& Locke, } \\
2003 \text { ) } \\
\text { "one of the most crucial aspects } \\
\text { of employee and client } \\
\text { management has to do with how } \\
\text { skillfully emotions are handled" } \\
\text { (Boren, 2010, p. 3) }\end{array}$ & $\begin{array}{l}\text { "biculturalism may help with } \\
\text { self-esteem issues and that } \\
\text { active coping is a crucial, yet } \\
\text { understudied, contributor } \\
\text { to how Latino individuals feel } \\
\text { about themselves" (Torres \& } \\
\text { Rollock, 2009, p. 7) } \\
\text { Depressive symptoms and } \\
\text { depressive disorders among } \\
\text { Hispanics in the United States } \\
\text { have grown significantly over the } \\
\text { past } 2 \text { decades. And early } \\
\text { community studies indicated that } \\
\text { Hispanic populations have higher } \\
\text { rates of depressive symptoms } \\
\text { than majority white populations } \\
\text { (Lewis-Fernández, Das, Alfonso, } \\
\text { Weissman, \& Olfson, 2005) }\end{array}$ \\
\hline
\end{tabular}




\begin{tabular}{|c|c|c|}
\hline & $\begin{array}{l}\text { Emotional Intelligence, defined } \\
\text { as "an array of personal, } \\
\text { emotional, and social abilities } \\
\text { and skills that determine how } \\
\text { well the individual functions in his } \\
\text { or her given environment" (Bar- } \\
\text { On, 2010, p. 12) }\end{array}$ & \\
\hline Physical & $\begin{array}{l}\text { According to Inc. and } \\
\text { Entrepreneur magazines, } \\
\text { entrepreneurs who maintain } \\
\text { fitness regimens of rigorous } \\
\text { exercise are more effective in } \\
\text { goal attainment expressed as } \\
\text { intrinsic and extrinsic rewards. } \\
\text { (Hanft, 2003). This hypothesis } \\
\text { was in fact confirmed by } \\
\text { Goldsby, et al in a study made on } \\
\text { 2005, where } 366 \text { small business } \\
\text { owners in the Midwest (Indiana, } \\
\text { Ohio, Illinois, and Kentucky) were } \\
\text { analyzed, a positive relationship } \\
\text { was found between the amount } \\
\text { of running and the attainment of } \\
\text { rewards by entrepreneurs. } \\
\text { Specifically, entrepreneurs who } \\
\text { regularly run, are more likely to } \\
\text { attain personal satisfaction, } \\
\text { independence, and autonomy } \\
\text { (Goldsby, Kuratko, \& Bishop, } \\
\text { 2005) }\end{array}$ & $\begin{array}{l}\text { According to Latinvision, a New- } \\
\text { York based company that } \\
\text { connects and promotes Latino } \\
\text { businesses, entrepreneurs, and } \\
\text { professionals in the United } \\
\text { States, the median age for Latino } \\
\text { entrepreneurs is } 44 \text { years } \\
\text { (Latinvision Entrepreneurs, 2012) } \\
\text { Additionally, another major } \\
\text { physical aspect is health, and } \\
\text { with that health insurance } \\
\text { possession. In fact, according to } \\
\text { a Gallup Poll, Latinos or } \\
\text { Hispanics are the demographic } \\
\text { with the highest rate of uninsured } \\
\text { individuals in the United States at } \\
41.5 \% \text { (Mendes, 2009). }\end{array}$ \\
\hline
\end{tabular}

\section{Successful Entrepreneurship}

Though many would define success as: "a favorable or desired outcome; or the attainment of wealth, favor, or eminence" (Britannica Academic Edition, 2012, p. 2), this is not always the case when it comes to entrepreneurship. Being a successful entrepreneur can simply mean that the business has survived for a year, five years, or ten years. In fact, failure in entrepreneurial ventures is much more common than survival. According to Scott Shane "only $48.8 \%$ of the new establishments started between 1977 and 2000 were alive at age five" (2009, p. 3). Only 29\%of new business 
ventures started between 1992 and 2002 remained after a ten year period (Shane, 2008, p. 6). Therefore if a business survives at all, it should be considered to be successful.

Just as with the definition of successful entrepreneurship, many researchers have tried to define or describe what makes a successful entrepreneur. Some of the most comprehensive and concise resources describing what defines a successful entrepreneur is displayed in the following table (Table 6).

Table 6

Historic analysis of entrepreneurship (Samli 2009, p. 29)

\begin{tabular}{|c|c|c|}
\hline Author & Year & Definition or Description \\
\hline Cantillion & 1755 & Risk-bearers, directors of production \\
\hline Say & 1800 & Economic agent who organized and supervises production \\
\hline Walras & 1870 & Buyer of services to be used in production in fixed technologies \\
\hline Wieser & 1914 & Leaders as guiding forces in development process \\
\hline Schmoller & 1901 & $\begin{array}{l}\text { Individuals with initiative risk-bearing ability who are heads of } \\
\text { enterprises. They are born to command }\end{array}$ \\
\hline Weber & 1920 & $\begin{array}{l}\text { Those who have a firm character, an industrious work ethic, and } \\
\text { energetic attitude }\end{array}$ \\
\hline Sombart & 1909 & Those who are in a position striving for profit and rationalization \\
\hline Rou & & $\begin{array}{l}\text { Factor producers who can handle organization information and } \\
\text { combine them in production }\end{array}$ \\
\hline Walker & 1986 & Those who exercise organizational capabilities \\
\hline Menger & 1923 & $\begin{array}{l}\text { Those who are informed on the economic situation, and use this } \\
\text { information to produce high order goods }\end{array}$ \\
\hline Schumpeter & 1934 & Creative destructionists \\
\hline Samli & 2007 & Creative constructionists \\
\hline
\end{tabular}

*This table contains information that was originally published by Ebner (2005) and later adopted and revised by Samli (2009).

In addition to the definitions summarized in Table 6, the literature has also shown that there are several critical personal traits of entrepreneurs that produce positive 
outcomes for individuals that possess them. The following table, which contains a list of 11 critical traits and the practical implications of possessing such traits, provides an overview of the critical personality traits that an individual should have in order to become a successful entrepreneur (see table 7).

Table 7

Critical personal traits of entrepreneurs (Samli 2009, p. 30)

\begin{tabular}{|l|l|}
\hline Critical Traits & Implications \\
\hline Strongly well-developed ego & Trusting oneself to accomplish \\
\hline Recognizing and working with details & Ability to understand what needs to be done \\
\hline High level of energy & To display how hard work pays off \\
\hline Impatient in completing the work & Trying to achieve quickly and efficiently \\
\hline Contingency thinking & Thinking options way ahead of time \\
\hline Need to control the business & Fulfilling own dreams with all the workers \\
\hline $\begin{array}{l}\text { Above average intelligence with } \\
\text { "holistic" vision }\end{array}$ & Knowing where to go and how to get there \\
\hline Pragmatist point of view & $\begin{array}{l}\text { Knowing exactly what needs to be done } \\
\text { rather than dreaming }\end{array}$ \\
\hline Emotional stability & Avoiding panics and disruptions \\
\hline Strong desire to succeed & Proper level of ambition to finish the work \\
\hline $\begin{array}{l}\text { Certain key characteristics such as } \\
\text { alertness, experience in leadership }\end{array}$ & $\begin{array}{l}\text { A realistic decision maker who quickly } \\
\text { determines what is needed to be done }\end{array}$ \\
\hline
\end{tabular}

*This table contains information that was originally published by Yarzebinski (1992) and later adopted and revised by Samli (2009).

\section{Entrepreneurship in West Virginia}

Economy. West Virginia is the largest coal producer east of the Mississippi River and accounts for more than one-tenth of total U.S. coal production (Independent Statistics and Analysis, 2009). West Virginia has been a traditionally labor-oriented state that has been focused on the coal production industry for well more than 100 years.

While this has been good for the state's economy from a GDP point of view as it 
showed growth between 2008 and 2009 (United States Department of Labor, 2010), it has harmed workforce education levels. According to CNN's Annalyn Censky "The coal industry (in West Virginia) accounts for most of the local jobs and offers a decent wage, often to workers with little more than a high school degree. Coal miners, on average earn about $\$ 68,000$ a year, more than twice the median average for the state" (2011, $p$. 4), making coal mining an attractive alternative to college education.

The Ewing Marion Kauffman Foundation (2010), measured how well states are making the transition to a global new economy and ranked the state of West Virginia ranked second to last overall only ahead of Mississippi; the study also ranked West Virginia last in terms of workforce education, accentuating the necessity to diversify the workforce in the state and better educate future generations. With the state's economy doing poorly and the workforce education being subpar, the possibilities of making a successful transition to an innovation-based economy decrease.

However, it is worth mentioning that the State's economy is currently in a state of recovery and development. According to George W. Hammond, Associate Director, BBER, and Associate Professor of Economics, "The West Virginia economy has begun to recover from the Great Recession. The state added 11,600 jobs from the fourth quarter of 2009 to the second quarter of 2011 . That means that the state has now replaced roughly one half of the 23,000 jobs lost during the downturn. In addition, job growth in West Virginia during the recovery so far averaged 1.0 percent at an annual rate, slightly faster than the national growth rate of 0.8 percent" $(2011$, p. 14). Therefore it is safe to say that even though the state's new economy workforce may not be ranked very high in the country, it still has a positive economic outlook for the future. 
Rural Nature. There may be few lending institutions in rural environments, the effect of which is to limit access to capital, limit competition and options, and encourage risk averse and sometimes discriminatory behaviors. Moreover, entrepreneurs are less likely to encounter peers with whom they can share ideas and problems (Dabson, 2001, p. 14). This is an issue in the state of West Virginia because it is very rural in nature and networking possibilities amongst entrepreneurs are not widely available.

Along with the issue of poor networking conditions, Dabson claims that in a rural economy, "the lack of economic diversity may not be a problem in good times but dependency and complacency become embedded in the culture" (Dabson, 2001, p. 21). West Virginia has been a 'Coal-based' economy since the 1950s and it is becoming a victim of such complacency. Additionally, Dabson (2001) states that: agriculture, natural resource extraction, or a single manufacturing plant often dominates a rural economy, which is what is happening in West Virginia.

In rural economies the young and well-educated tend to leave. Rural people, by force of circumstance, may be more self-sufficient than their urban counterparts, but the culture of entrepreneurship tends to be weak (Dabson, 2001).

Opportunity Identification. There are several underlying factors to starting an entrepreneurial venture including: education; urban density; proximity to a university; college educated population; presence of infrastructure, like highways and broadband connectivity; and financial capital institution constituting an integrated framework that can later inspire an individual to start their own entrepreneurial venture (Fortunato \& Alter, 2011). 
Opportunity identification or creation may affect the actions of individuals and institutions. On the other hand, opportunities may be perceived by individuals who identify or create new opportunities through their endeavors, and by institutions whose productive and coordinating efforts may open new markets or create demand (Fortunato \& Alter, 2011).

Fortunato and Alter (2011) claim that there are two types of opportunities: opportunity discovery and opportunity creation. Opportunity discovery assumes that opportunities are separate from the entrepreneur, that they exist "out there somewhere" wanting to be found by skilled individuals capable of both identifying and exploiting these. While opportunity creation states that opportunities cannot be identified in advance because they are yet to be created, instead, entrepreneurs tend to assemble or effectuate opportunities out of the mundane realities of their everyday existence (Fortunato \& Alter, 2011). Both types of opportunities are critical for entrepreneurial development. While Fortunato and Alter's description of opportunity seeking and identification are very accurate, an additional dimension to the theory will be considered in this paper.

\section{Latinos in West Virginia}

There are very few Latinos in the state of West Virginia. The Latino population in the state only represents $1.2 \%$ of the state total, making it 50th in the nation, with roughly 22,268 Latinos in the state (American Immigration Council, 2012). The Latino demographic nationwide is rapidly evolving and its demographic impact on the nation is 
quickly changing. In the coming years, the Hispanic population growth will most impact communities that had relatively few Latinos a decade ago (Suro \& Singer, 2002).

Latinos have begun moving within the United States towards the Northern states. The Northwest has become a prime destination for Latinos within the U.S, but they are also beginning to occupy a significant portion of the Northeast demographic. The images below (Figures $7 \& 8$ ) depict the evolution that the Latino population has undergone during the past 25 years. The maps, taken from a U.S Census Bureau report (The Hispanic Population, 2010), show what the Latino occupancy was in 1980 and then again in 2006.

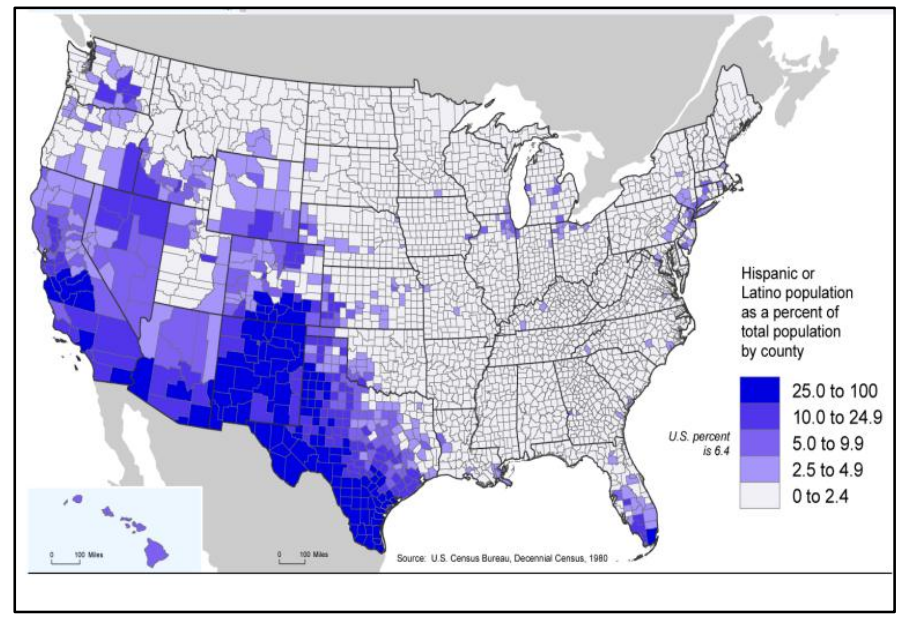

Figure 8. 1980 Latino Occupation (U.S Census Bureau)

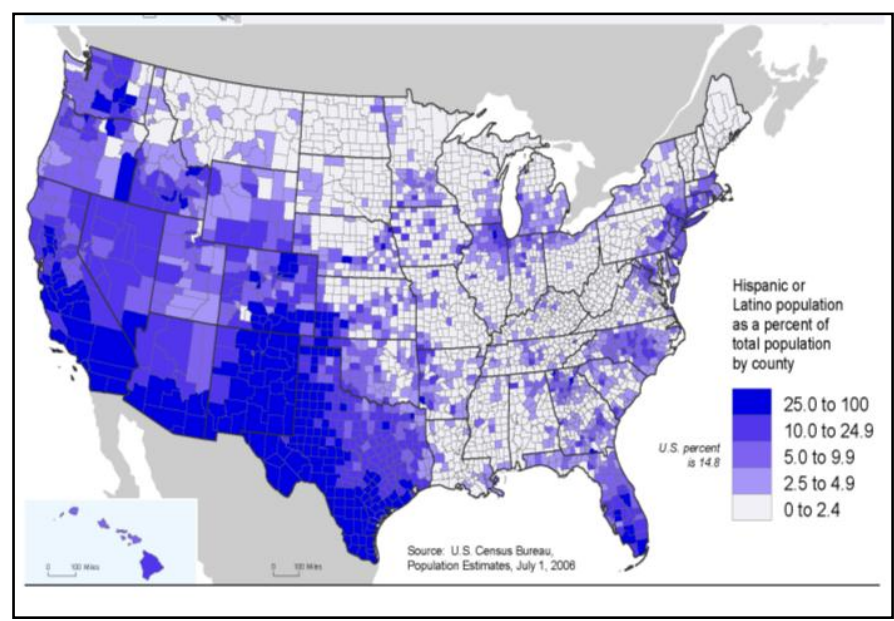

Figure 7. 2006 Latino Occupation (U.S Census Bureau)

The Latino population has been migrating within the United States and is now occupying a large portion of the West and beginning to occupy the East Coast. Latinos are now more heavily residing in Oregon, Washington, Utah, Idaho, Wyoming, South Carolina, North Carolina, Virginia, Washington D.C, New York, and Maryland. 
In terms of evolution within states, the Hispanic population has also grown exponentially during this past decade. The picture below (Figure 9) shows the percent change in population from 2000 to 2006 with detailed range information for each state.

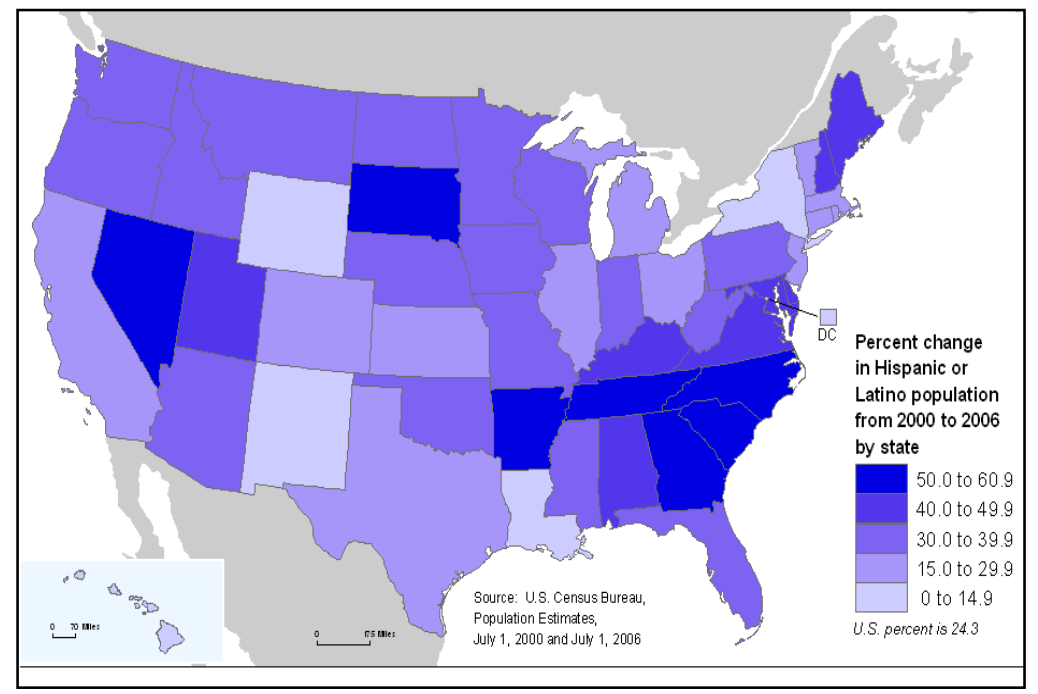

Figure 9. State Percent Change 2000-2006 (U.S Census Bureau)

The Latino population has grown considerably in most states; there were only six states in which the Latino population did not grow over $15 \%$ in this six year period: Louisiana, Hawaii, New York, Wyoming, New Mexico and Washington D.C. Table 8 provides a graphic distribution of the percentages that different states experienced in terms of Latino population growth. 
Table 8

Graphic distribution of the percentage change experiences by all 50 states.

\begin{tabular}{|ll|}
\hline Percent Change & Amount of States \\
\hline $\mathbf{5 0 . 0}$ to 60.9 & 7 \\
\hline $\mathbf{4 0 . 0}$ to 49.9 & 7 \\
\hline $\mathbf{3 0 . 0}$ to 39.9 & 17 \\
\hline $\mathbf{1 5 . 0}$ to 29.9 & 13 \\
\hline $\mathbf{0}$ to $\mathbf{1 4 . 9}$ & 6 \\
\hline Total & $\mathbf{5 0}$ \\
\hline
\end{tabular}

Clearly, the growth of the Latino population is no longer limited to just a few regions (Suro \& Singer, 2002). Latinos are moving, and quickly occupying previously unoccupied areas.

Difficulties for Latinos in West Virginia. The fact that there are such few Latinos in the state and a lack of ethnic concentration represents an obstacle to Latino entrepreneurship. Ethnically concentrated residential areas can provide profound ethnic resources such as low-cost labor and markets for ethnic goods and services, for coethnics members to start new businesses (Wang \& Wei, 2007). It has been frequently observed that immigrant entrepreneurs are notably non-individualistic; they have strong families and communities that enable them to pool resources. The more organized and collectivized the immigrant community, the more successful they are likely to be in establishing themselves as entrepreneurs (Light, 1972).

The size of the ethnic market is a factor that conditions direction of selfemployment (Spener \& Bean, 1999). The issue of community also has implications for access to markets, capital, labor, peers, and infrastructure, as well as the impact it has 
in shaping cultural attitudes towards entrepreneurship (Dabson, 2001). The few Latinos that live in the state experience a lack of peer support. Traditionally, the immigrant network literature sustained that the presence of relatives and friends at the place of destination and thus lowered the costs, both monetary and psychological, of migration (Verdaguer, 2009).

Wang and Wei (2007) agree with the authors above, as they claim that social capital and ethnic networking play a key role in the flourishing of ethnic enterprises, not to mention prime location for business activities: a ready source of lower cost labor, credit and a more homogeneous market, well understood and common consumer preferences, various tangible and intangible resource networks, common religions, similar trust systems, and ability to enforce this trust. They also state that public attitude toward ethnic minorities and immigrants can exert influence on entrepreneurship (Wang \& Wei, 2007).

The larger the immigrant group, the more favorable the niche for ethnic entrepreneurs, since their potential market is larger (Evans, 1989). If Latinos do not see a large immigrant group already present in the state they wish to migrate to, the decision to do so may be changed because of that weak Latino presence. According to Evans (1989) there are two different hypotheses addressing this issue: the Group Hypothesis and the Isolated Labor Pool Hypothesis. The Group size hypothesis states that the larger an immigrant group, the more likely are its members to establish their own business. This creates an issue for the state of West Virginia as the immigrant group occupying the state is very small, and the establishment of Latino businesses may be affected by that. 
The Isolated labor pool hypothesis states that the greater the percent of adults in an immigrant group who are not fluent in the host country's language, the more likely are group members to be entrepreneurs. This hypothesis only works well when the first hypothesis is also true. If there is a weak Latino presence in West Virginia, and there is no market to cater to, Spanish speaking entrepreneurs will not be successful.

Ethnic Enclave. An ethnic enclave is another issue that affects Latinos that wish to move to and open up their businesses in West Virginia. Because of the way Latinos tend to do business, they are more like to be self-employed in areas that have larger Hispanic populations and they usually tend to a more concentrated demographic in a certain geographic area (Shinnar \& Young, 2008).

Immigrant entrepreneurs tend to start out with few resources and lack access to mainstream sources of financial and technical assistance, their ties with other coethnics are important. Ethnic solidarity plays an important role in the business start- up process, from securing financial capital to finding employees. Entrepreneurs need to rely on trusted relationships with relatives or friends for information on everything from business permits, commercial laws, business locations, management practices, and reliable suppliers (Waldinger et al. 1990). Ethnic entrepreneurs gain economically by providing goods and services to the ethnic population, while co-ethnics benefit by being employed by entrepreneurs based primarily on co-membership in the ethnic group. Often co-ethnic employees gain entrepreneurial experience through such employment and later use that experience to start their own enterprises (Light \& Gold 2000). Immigrant entrepreneurs may continue to use ethnic resources to maintain and expand 
their businesses, though recent scholarship suggests that entrepreneurs draw more on class resources once their businesses are established (Zarrugh 2007).

An ethnic enclave is what is missing in the state, as it provides a source of both low-cost workers and spatially concentrated consumers (Shinnar \& Young, 2008). Latinos may not be able to succeed entrepreneurially unless some sort of ethnic enclave is created in the state. Ethnic enclaves are essential to success as they also provide a linguistically isolated labor pool with skills that can be more efficiently tapped into by co-ethnic rather than majority group entrepreneurs (Shinnar \& Young, 2008). Language/Accent. Braverman (2011) found that people usually like people that speak in a similar way that they do much more than those who speak differently. This is an issue for the few Latinos in the state of West Virginia, because there is a very small Latino community. According to a study completed by Scales et al., "Mexican English" was found to be the least appealing accent and most difficult to understand when compared to Chinese English, Native English, and British English (2006). Accent appears to play a critical role in the way language barriers are diminished or increased, and the way other races are accepted in a community. Individuals tend to be naturally wary of something they deem difficult to understand. Scales' study (2006) also revealed that Mexican English speakers were perceived to have bad pronunciation, be annoying/irritating and less educated than the other speakers, representing a major issue for Latinos as they are not given a chance to prove themselves as knowledgeable individuals that can succeed and help the economy thrive.

Communication is critical in the workforce, and accent can be seen as a problem that significantly disadvantages Latino workers and entrepreneurs in the United States. 
Consequently, English fluency has become a highly valuable aspect of human capital for Hispanic workers, even above more important factors like education, job training, and work experience (Yang, 2005). Evans (1989) found that immigrants fluent in the host country's language can deal more readily with organizations such as suppliers and banks outside the ethnic market, so it is plausible that fluent people should be more likely to own businesses. 


\section{CHAPTER 3 - METHODOLOGY}

\section{Research Design}

This research was designed as a preliminary and exploratory study as a foundation for future studies that might expand into other demographics, geographic areas, and fields of study. This study was addresses the following research questions:

- Why are there so few Latino Entrepreneurs in West Virginia?

- What are the entrepreneurial issues identified by Latino business owners in West Virginia?

Both qualitative and quantitative research was involved. The qualitative portion of the study was both interview and survey based, and included a telephone interview (a short demographic interview and a 30-question business owner interview) or the completion of the questionnaire (see Appendix 5 and 6 ) via email, and theme creation. While quantitative data obtained in this study will mainly be used to create statistics and provide a demographic snapshot of the Latino business owners in West Virginia.

The thematic-analysis was used as a starting point for developing an understanding of the personal experiences of Latino entrepreneurs in West Virginia. The primary themes discussed by participants and the issues recognized in secondary data were combined into the Latino Thriving Environment Model explaining the broader concerns of Latino entrepreneurs in order to address the above research questions. The model was then used to complete a SWOT analysis in order to provide a starting point in which to: help potential Latino and non-Latino business owners in West Virginia to 
start their business more efficiently and find out how to mitigate the issues and obstacles that are presented to Latino entrepreneurs.

\section{Question Development}

The survey questions were developed taking into consideration the research questions above, with the idea of getting to know and understand the individuals as well as their businesses. The first demographic questions were fairly general and easy to answer. This provided an opportunity for the participant to get acquainted with the interviewer and comfortable with the interview process. Then the latter part of the demographic portion of the interview was designed to focus on more specific details of the individual's family life, and thus to gain an understanding of his or her family values.

Following the demographic portion, the questions became more business oriented and semi-structured allowing for open ended questions and follow-ups depending on the participant's answers. These questions were also divided into two major categories: (1) Type of business owned/Operations and (2) Economic Nature/Governmental support. These provided an understanding of the internal functioning of the business as well as the external environments. The second category came last to assure that the participant had reached a certain comfort level before talking about government to capture most honest response possible.

\section{Participants}

The study was delimited to current, legal, first-generation Latinos and their descendants as identified by the U.S Census Bureau in West Virginia. According to the U.S Census Bureau there are approximately 84 Latino Business owners in the state. 
The eight individual interviews included represent around 10 percent of the population yielding credible and useful findings.

First-generation Latinos are more likely to face stronger language and acculturation challenges than second- and third-generation Latinos, but the experiences of all generations were taken into consideration to build a rich understanding of the barriers faced by individual and diverse entrepreneurs. The study was delimited to legal immigrants because the U.S Census Bureau does not take into consideration illegal aliens that have started a business in the state.

\section{Informed Consent}

The interview process and questions were cleared by the Institutional Review Board (IRB) at West Virginia University. The interview and consent forms were presented in both English and Spanish. Subjects were allowed to choose their preferred language. The level of linguistic comfort was critical as it allowed the individuals to open up to the interviewer and disclose information in a much more relaxed manner.

The consent form cover letter, which can be seen in Appendix 2 \& 3, in English and Spanish respectively, was provided to the subjects via email prior to collecting any sort of information to allow each to make the decision of whether they wanted to be interviewed or not. The cover letter and interview documents in Spanish were certified by a Spanish speaking expert to confirm that the translation of the documents from English to Spanish was in fact accurate. See Appendix 4. 


\section{Confidentiality}

IRB regulations and general scientific practice require that confidentiality of research participants be ensured. These regulations are in place to guarantee the privacy of each person who chooses to participate in any particular research study. For this particular study, the individual was assured and guaranteed, that his or her name, the name of the business, financial information divulged, telephone numbers, addresses, or any sort of information that could potentially identify an individual or his or hers business in the study was not divulged to the public and/or divulged in this dissertation.

The telephone interviews were transcribed by the researcher himself, and the individuals were numbered from one to eight instead of utilizing names or pseudonyms. The surveys were transcribed verbatim in order to maintain complete consistency with the business owner's responses. Data is presented as descriptive statistics and numbers to further ensure the confidentiality of those willing to participate in this study.

\section{Geographic Location}

The sampling frame for this particular study was delimited to the state of West Virginia. However, 90 percent of Latino business owners identified were located in the eastern part of the state in Morgan, Berkeley, and Jefferson counties, near Washington, D.C and thriving, populous Northern Virginia (Figure 10). Business owners in the more rural counties that form the majority of the state were very difficult to identify, and only two of the eight business owners operated their business in Charleston, the capital of the state, or more specifically in Kanawha County. 


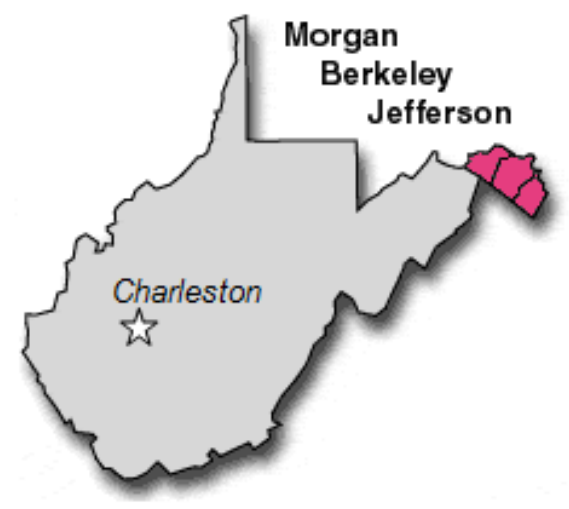

Figure 10. West Virginia Map depicting Morgan, Berkeley and Jefferson counties. (FRIS 2012)

Some explanation of the "Eastern Panhandle" phenomenon might be derived from U.S Census (2010) findings stating that Latino business owner's number approximately 28,738 in Virginia and 25,877 in Maryland, numbers that far surpass the estimated 84 Latino business owners in West Virginia.

\section{Data Collection}

The Small Business Development Center (SBDC) central office in West Virginia provided a list of 20 Latino business owners in the West Virginia. The list was analyzed, and business owners that were still available were contacted. Only four of them decided to do the interview, while other four completed the written survey.

The eight business owners identified as willing to participate received the confidentiality cover letter in both Spanish and English via email, and were asked to provide a time slot for a 20 to 35 minute interview. The business owner was contacted at the time selected and the interview process, which lasted an average of 25 minutes, 
began. The interviewee was allowed to choose whether they wanted the interview conducted in Spanish or English. This option was provided to make the subject as comfortable as possible since some of the information to be divulged might be sensitive to some individuals.

The data collection process of this study followed the established interview questions (Appendix $5 \& 6$, English and Spanish respectively) which contain a demographic portion in addition to a more in-depth business-oriented section. The demographic portion of the interview established age, origin, migration patterns, number of siblings, and marital status. All of these questions are important to better understand the business owners, their background, and the motivation they had to start a business in the United States. Information obtained from the business owner segment of the interview was used to analyze the way the business owners started their businesses, the success of the business, type of business, business experience, number of employees, and funding utilized.

\section{Authenticity and Reliability of the Study}

The study conducted for this research utilized a semi-structured interview that included demographic questions and thirty business-related open-ended questions that allowed the participants to respond however they desired. This questionnaire was also used for the surveys that half of the respondents chose to do rather than the interview. Some participants discussed questions at length while others were a lot more concise and went straight to the point. Half of the interviews were done via Skype using MP3 Skype Recorder 3.1 to record each interview in its entirety while the other half was 
conducted as a survey style interview in which the participants filled out information and e-mailed the survey back to the researcher. An interview protocol was followed for each interview in which the purpose of the research was explained to the participant to ensure transparency.

After the interview process was completed, and the interviews were personally transcribed. The interviewees with e-mail addresses were contacted to "member check" their responses and make sure they did not feel misrepresented by the transcription. This type of fact checking was not necessary with the participants that used the survey, because of its written format. Those without an e-mail address (half of the oral interviewees) were checked orally immediately after the recorded interview. Member checking is critical to the veracity of the study it engages participants to review the accuracy of their responses after the interview and the study's results after the interpretation (Cresswell, 1998), providing a much more valid end product.

\section{Data Collection Process}

The goal of this research study was to explore and understand why there are so few Latino Entrepreneurs in West Virginia, and to discover entrepreneurial issues as identified by Latino business owners in the state. The Small Business Development Center collaborated by providing a list of 20 Latino owned businesses in West Virginia which represented about $25 \%$ of the totality of relevant businesses in the state. These 20 businesses were all contacted via email, and/or via telephone. One of the biggest issues in getting in contact with the business owners was the fact that out of the 20 business owners only four provided an e-mail address. Five of the phone numbers on 
the list had been disconnected recently. Three business owners had left their business and gone back to Mexico. Four business owners refused to help with the research. This left only eight business owners available to participate in the study out of that particular list.

Each participant was either sent an email or called via Skype in order to introduce the study and explain the nature of the study. Four of the participants were willing and able to do the interview via telephone, which was recorded via Skype and later transcribed. The other four participants, were not willing or able to do the telephone interview, and instead opted to complete the questionnaire as a survey and email it back to the researcher. Participation in this study was completely voluntary and the participants did not receive any reward for participation. Each participant was provided with the cover letter (Appendix $2 \& 3$ ) further explaining the study and each one agreed to participate either orally or via email. The participants that were interviewed via telephone were also interested in receiving a copy of the final product and will be contacted after the dissertation has been completed.

\section{Timeframe}

The timeframe for the interviews was highly concentrated. The business owners were all contacted and interviewed between the first and third week of November 2012. The business owners that were willing to help were understandably busy most times; therefore patience was critical to completing all of the interviews. The telephone interviews lasted from 15 to 45 minutes as some of the business owners expanded on their responses a lot more than others, while the survey style responses were mostly short answers and very straightforward. 


\section{Interviews Development}

Most business owners that agreed to be a part of the study were quite nice and open about their businesses. There was however, one particular question regarding earnings that the majority of business owners chose not to answer. Most of the participants discussed the questions asked at length, and went above and beyond when responding the questions. Some went on to tell very personal stories about their experiences that provided an even better insight into their lives and the way in which the decision to start a business has affected their personal lives.

The interviews usually started very slowly with concise responses to the first 15 questions, comprising the demographic portion of the interview. Many participants seemed shy or even reserved when responding to the questions. Once the interview moved on to the business owner portion and focused more on the business, most participants opened up and began expanding on their responses.

\section{Survey Development}

In order to highlight the importance of the human aspects of entrepreneurship (adapted from McFall, 1998), the demographic portion of this study utilized a long interview style construction introduced by McCracken (1998). This allowed for an understanding of not only the entrepreneurs, but the individuals as well. Additionally, the utilization of such type of survey allowed for the interviewer to better understand the entrepreneurial and non-entrepreneurial issues affecting Latinos in West Virginia.

The survey instrument was modified as a response to the fact that many business owners that wanted to participate in the study just did not have the time to be 
interviewed for 20 minutes. The questionnaire was a way to provide an option that could be completed at their own pace on their own time. The surveys were completed by four business owners. Two of them completed and returned them within two days, while the other two business owners took about a week and a half to complete the survey.

The survey responses were similar to the interviews in the sense that the demographic portion was always very concise and did not allow for much elaboration on their part. Meanwhile, the business-oriented portion of the questionnaire elicited more depth and elaboration.

\section{Challenges}

There were many challenges to completing the interviews successfully. These challenges included but were not limited to the following issues:

Trust: Many of the business owners that decided to participate were hesitant to discuss personal and business information with an unknown person at first. It was quite difficult to convince some of the business owners to help with the study. Four business owners actually refused to be a part of the study because they did not feel comfortable sharing information with a stranger.

Contacting business owners: While the list obtained from the Small Business Development Center made it much easier to find and contact some of the business owners, it was quite difficult to send the cover letter to some of them and obtain the questionnaire from them. More than half of the participants stated that they did not have an email address, and had to use their friends or family's email in order to receive the cover letter or send back the questionnaire. 
$>$ Discussing the most critical questions: Six of the business owners that participated in the study chose not to answer the question dealing with income. This is an issue because it would have been interesting to gain an understanding of how much income these individuals make on a yearly basis. This would have helped create a comparison with the national average, to see if the Latino business owners in the state are thriving and living above the average income for Latinos. Either way it would have been positive to obtain this information as it could have helped to motivate other Latinos to start their businesses in West Virginia if the response was widely positive.

Punctuality: Business owners that participated in the study were quite busy on a daily basis, and it was difficult for them to make room to do the interviews. This was however a big problem because business owners would provide a date for the interview and then not even be present in the business at that particular time, making for some very late nights and wasted money (Skype credit).

Desire to help: When 20 percent of the business owners that had been identified chose not to be a part of the study it posed a problem for the researcher. This was a limited pool and more participants would have been better. It was however, understandable that some individuals just did not feel comfortable sharing sensitive information with a stranger.

Knowledge of other Latino businesses: One of the potential ways in which the study was supposed to obtain more participants was by using a snowballing effect. After every interview was completed the business owner was asked to provide the name of any other Latino they knew that had a business. Only one of 
the participants said she knew another Latino business owner, but decided not to provide their information because they were the competition and did not get along. So, the fact that the Latino business owners contacted claimed they did not know any other Latino business owners in the state, made for a much more difficult data gathering process. 


\section{CHAPTER 4 - RESULTS AND FINDINGS}

\section{Participant Description}

Seven of the business owners interviewed for this research were women, while only one of the participants was a man. Four of the participants described their business as a "joint venture" between them and their significant other or a close family member. The other four reported as sole proprietors of the business. The majority of the business owners were in the range of 34 to 50 years of age. The oldest business owner interviewed is 62 years old, and the youngest 34 years old. The average age of the entrepreneurs was 49 years. When discussing education and academic success, all of the participants had completed high school but only three of them had gone on to do some sort of university degree, whether it was at a junior college or at a University.

Six of the business owners were born in Mexico. One was born in the Dominican Republic, and one in Ecuador. This large proportion of Mexican business owners in the state is consistent with the number of Mexican immigrants in the United States that own their own businesses. On average, the business owners have been in West Virginia for about 9 years. The majority of business owners have lived in West Virginia for between 5 and 15 years. Two of the business owners have lived in the state less than 5 years. One has been living in the state for over 15 years. Only one business owner has been in the United States for less than five years, while five of them have been in the country for 5-15 years and two of them for over 15 years. It is worth noting that those who have been here for a longer period initially came to Virginia, Maryland, or Washington D.C, and thus moved to West Virginia. 
In terms of language ability, five of the Latino business owners spoke fluent English and chose to do the interview or fill out the survey in English. Three of the participants did not feel confident enough in their abilities to discuss their business in English. It is worth noting however, than when asked about obstacles in their businesses and their experience in West Virginia, language never came up as being an issue. However, a major connection between English fluency and business success that was discovered in this study and will receive further discussion later in the document.

Of the business owners that participated in this study, only two were not, or had never been, married. Two of the business owners were widows, while the other four participants were all married. Additionally, all but two of the participants had children, generally two. The participants of the study were also mostly Catholic. Six described themselves as Catholic, one decided not to answer the question, and one described herself as Protestant. Finally, when asked about their motivation or experience in regards to opening a business, five of the respondents described a history of entrepreneurial ventures in their family before starting their own businesses. The following table (Table 9) summarizes the participant description. 
Table 9

Demographic Profile of Participants

\begin{tabular}{|llrr|}
\hline Variable & Attribute & Number & Percentage \\
\hline Gender & Male & 1 & $13 \%$ \\
\hline & Female & 7 & $88 \%$ \\
\hline Age & $18-34$ & 0 & $0 \%$ \\
\hline & $35-50$ & 4 & $75 \%$ \\
\hline & 51 or older & 2 & $25 \%$ \\
\hline College Education & Yes & 2 & $25 \%$ \\
\hline & No & 6 & $75 \%$ \\
\hline Country & Ecuador & 1 & $13 \%$ \\
\hline & Mexico & 6 & $75 \%$ \\
\hline & Dominican Republic & 1 & $13 \%$ \\
\hline Stay in U.S (years) & $0-5$ & 1 & $13 \%$ \\
\hline & $0-15$ & 5 & $63 \%$ \\
\hline & 15 or more & 2 & $25 \%$ \\
\hline Stay in W.V (years) & $0-5$ & 2 & $25 \%$ \\
\hline & $5-15$ & 5 & $63 \%$ \\
\hline & 15 or more & 1 & $13 \%$ \\
\hline English Proficiency & Basic & 3 & $38 \%$ \\
\hline & Intermediate & 2 & $25 \%$ \\
\hline & Advanced & 3 & $38 \%$ \\
\hline Marital Status & Married & 4 & $50 \%$ \\
\hline & Single & 2 & $25 \%$ \\
\hline & Other & 2 & $25 \%$ \\
\hline Number of Children & 0 & 2 & $25 \%$ \\
\hline & $0-2$ & 5 & $63 \%$ \\
\hline & more than 2 & 1 & $13 \%$ \\
\hline Religion & Catholic & 6 & $75 \%$ \\
\hline & Protestant & 1 & $13 \%$ \\
\hline Other & 1 & $13 \%$ \\
\hline Entrepreneurial Family & Yes & 5 & $63 \%$ \\
\hline No & 3 & $38 \%$ \\
\hline & & & \\
\hline
\end{tabular}

The most avoided response in the questionnaire, and the one that only one of the business owners chose to answer, had to do with annual income of the business and monthly income of the household. The one business owner that answered the question stated that her business grossed 1.5 million dollars a year, but did not disclose net 
income. The data shows that the other participants simply did not feel comfortable releasing that type of information for the survey or interview.

\section{Previous Work Experience}

The data showed that most of the business owners interviewed had never owned a business before, and their education was unrelated to business ownership or nonexistent. The individuals interviewed had to learn as they went how to start and sustain a business. Participant two stated:

Participant two: I had studied interior design in college and had no idea how to start a business when my friends told me to start selling my product; I decided to start my business with an initial $\$ 800$ investment from a friend. But it was not easy; I did not know how to start a business and had no idea I was going to have to do so many things regarding labels, FDA approval, trademark and copyrights.

This business owner however, managed to succeed by using Google as her main source of information to start her business. She started her business without a business plan and established a company without any prior entrepreneurial or educational experience. Some of the other business owners learned from family members how to start and run a business, but had no real training. And others just observed the way the business they were working in was run and imitated that process.

Even though some of these individuals and businesses have been successful, it is clear from this response that lack of expertise, education, and experience can be a 
major roadblock when starting and while running a business. So why did these people start a business? What was their motivation?

\section{Motivation for Starting a Business}

Latinos are well known for having an entrepreneurial spirit, which works as a motivating factor when it comes to starting a business (Zimmerer, Scarborough, \& Wilson, 2010). For most of the participants in this study, the fact that their families had a history of owning businesses became a critical component of their entrepreneurial spirit.

The idea of business ownership, and the entrepreneurial spirit, is something that many prior studies have determined to be related with family involvement in entrepreneurial ventures. This present study confirms that theory. Sixty-three percent of the business owners interviewed reported some sort of previous experience with business ownership.

When it comes to prior work experience, some of the business owners had worked in other sectors before starting their own business. Others had always worked in that particular industry. And one business owner in particular had a completely different reason for starting her business. Participant two had this to say about the reason why she started her business:

Participant two: "Friends always insisted I should start a business selling [condiments], because every time I made it they would love it. In fact they signed me up for this contest, without me knowing, and I actually won. So when I got the $\$ 800$ loan from a friend, I decided to start my business and see what happened" 
In addition to the entrepreneurial spirit, the business owners stated many different but intertwined reasons to start their businesses. Some stated that they wanted to be freer at work and have more autonomy, while others stated that they just saw an opportunity to take advantage of a need and decided to start a business. Another business owner did it because friends advised her to do it. Yet another started a business because she thought it would be better than working for someone else and wanted to follow her passion. All of these reasons for starting a business are connected in the sense that the idea of owning a business is better than being an employee, or at least these business owners perceived it that way. Independence, autonomy, freedom, passion, and opportunity are some of the most critical words utilized when asked about the reason for opening a business of their own.

Not all of the business owners however were satisfied with their decision to start a business. Participant three said:

Participant three: Yo pensé que esto iba a ser muchísimo más fácil y mejor para mí y mi familia. Lamentablemente estaba equivocada, este negocio ha arruinado mi familia, mi esposo ya no está con nosotros gracias al negocio, mi hermana y yo estamos en un montón de problemas, y la gente ya no compra nada, la economía no ayuda y este negocio está perdiendo plata diariamente. [I thought this was going to be a lot easier and better for my family. Sadly I was wrong. This business has ruined my family. My husband is no longer with us due to the business. My sister and I are in a bunch of trouble. People don't buy 
anything anymore. The economy doesn't help and this business is losing money on a daily basis]

\section{Business Distribution}

The data demonstrated that business owners interviewed fell into three major categories:

Restaurants/Food service: There were two business owners that had a restaurant, one that had a catering service, and one that produced [condiments] for major supermarkets and chain stores.

Grocery store: There were two business owners that had started a Latino grocery store in the state of West Virginia.

Other services: There was one business that provided advice for business owners and one children's day care.

This business distribution is important because it is consistent with National Statistics in the literature review. Latino businesses in the United States tend to focus on Grocery store and Restaurant/Food related businesses. Of the businesses interviewed 75 percent actually owned businesses related to one of the two major areas for Latino business creation. The data showed that the concentration upon these two types of businesses may be a potential reason for the lack of Latino businesses in the state. Out of the six business owners that had businesses in these industries, only the two that did not cater to the Latino market, are actually thriving right now. 
As demonstrated by the data, Latino grocery stores are the type of businesses that require market demand in order to succeed. In a state like West Virginia, which has the lowest percentage of Latinos in the United States, it is very difficult to succeed with businesses of that nature.

When it comes to employees, three of the business owners interviewed stated that they had no employees and were only helped by family members, while four of the businesses had between one and five employees. Just one business had more than five employees. The business owners interviewed had been in businesses for at least five years. All of them had managed to survive for over five years and two of them actually have been open for over 10 years. Participant three however, described her situation as critical and stated:

Participant three: Yo no sé qué voy a hacer, pero si la situación continúa como esta me va a tocar cerrar el negocio en seis meses. Ya es muchísimo tiempo que estoy perdiendo dinero, y no puedo seguir así, así es que si para Junio no cambia la situación, cierro el negocio y me dedico a hacer otra cosa II don't know what I am going to do, but if the situation continues as it is I am going to have to close down the business in six months. It has been a long time since I started losing money, and I can't continue this way, therefore if by June the situation does not change, I am closing down the business and I'll focus on doing something else] 
This study has discovered a direct relationship between Latino businesses in West Virginia that aim for a Latino market and their lack of success. The data pointed to the fact that business owners who described their businesses as not having many or any Latino customers are thriving and succeeding in the state.

Table 10

Business Description

\begin{tabular}{|llll|}
\hline Variable & Attribute & Number & Percentage \\
\hline Type of Business & Restaurant/Food Service & 4 & $50 \%$ \\
\hline & Grocery Store & 2 & $25 \%$ \\
\hline & Other Services & 2 & $25 \%$ \\
\hline Number of Employees & 0 or family & 3 & $38 \%$ \\
\hline & $1-5$ & 4 & $50 \%$ \\
\hline & More than 5 & 1 & $13 \%$ \\
\hline Length of Ownership & $0-4$ & 0 & $0 \%$ \\
\hline & $5-10$ & 6 & $75 \%$ \\
\hline & more than 10 & 2 & $25 \%$ \\
\hline Latino Client Base & Yes & 5 & $63 \%$ \\
\hline & No & 3 & $38 \%$ \\
\hline
\end{tabular}

\section{Findings}

The most pressing issues found in this dissertation are: Sense of Community, Expertise level, Governmental support, Trust issues - Discrimination (Perception), and Market Demand. 


\section{Sense of Community}

One of the most important findings in this study has to do with lack of sense of community among the business owners interviewed. Most of the business owners discussed the fact that they do not work with others in order to make their businesses better. Instead, they seemed to be happier working by themselves and do not seem to have healthy relationships with other Latino businesses in the area. When asked if they knew of another Latino business owner in their area, participant three responded like this:

Participant three: "Si, hay otra tienda latina aquí en el pueblo, pero a nosotros no nos gusta hablar con ellos, ellos no saben hacer las cosas bien y nos roban los clientes"

[Yes there is another Latin store here in town, but we do not like to speak to them, they don't know how to do things right and steal our clients].

Additionally, some of the businesses interviewed do not even purchase their goods in West Virginia, which adds to the lack of local support. Participant three said:

Participant three: "Yo compro todos los productos que necesito en un wholesaler en Washington, D.C, es mucho más económico que comprar productos aquí en West Virginia y es relativamente cerca" 
[I buy all the products I need in a wholesaler in Washington, D.C. It is much cheaper than buying products here in West Virginia and it is relatively close by].

It is worth noting however, that one of the business owners interviewed has taken it upon herself to try and help her community as much as possible. She started a business in which she provides advice on how to start a successful business and provides business advice. This business idea came to her precisely because she saw the same type of disconnect between the community and business owners that I have seen. Participant seven stated:

Participant seven: I just think that it is important for these people to hear the experience that I had when I started my first business with just very little money. I am a big believer in the power of the mind, and I believe I can help these people start a successful business by showing them how to work together and use the power of their mind

Despite the reported lack of Latino community, many business owners were willing to provide their version of what is necessary and critical in order to start a successful business. Participant one provided the following advice:

Participant one: If you are going to open a business, make sure that you maintain a quality that is over the top, because that is what it boils down to. If you don't like what you do, and you open your business just because somebody said it 
would be a good business to open, it is not going to work. I work 7 days a week, 24 hours, because if people require a party on a Sunday then good-bye Sunday. So make sure whatever you do you do it right, and the services that you offer are top of the line

\section{Expertise Level}

Lack of expertise managing and starting a business seemed to be a fairly common theme throughout this study. Out of the business owners interviewed, none had had business education or had even taken a class on entrepreneurship or business development. They all used different resources in order to start their businesses (past experience, the Internet, family, or even just trial and error) until they found a way to deal with their issues. This lack of expertise however did not seem to matter to the business owners when they were starting their business, as they did not seek help from any governmental agencies. Only one of the business owners sought the help of the SBA and found herself with a bunch of brochures and no answers.

When asked about their business experience several business owners interviewed discussed the fact that their families had traditionally owned businesses in their home countries, in fact participant three stated:

Participant three: Nosotros siempre hemos tenido negocios en mi familia.

Cuando vivíamos en Ecuador mi abuelo tenía una tienda, y mi papa la empezó a manejar cuando yo era muy joven. Entonces para mi es normal tener un 
negocio, además que he tenido la posibilidad de aprender de mi papa a manejar los clientes y los distribuidores, lo cual me ha ayudado muchísimo a montar mi negocio actual

[We have always had businesses in my family. When we lived in Ecuador, my grandfather had a grocery store, and my dad began to manage it when I was very young. Therefore for me it is normal to have a business. Besides, I had the chance of learning from my father to handle clients, and suppliers, which has helped me a lot in starting my present business]

Additionally, the capacity to control or account for growth is another major component of expertise that entrepreneurs need to have. When asked about the things that were important for a small business, another aspect discussed by the business owners was size, just how big should the business be and the possibility of growth. Participant one responded that:

Participant one: It depends on how many people you have to support. If you have a family of 10, it's not the same than supporting a family of two. Keep it in control, because when it falls in the hands of people that don't care, everything goes down because you are relying on other people

Participant two described how uncontrolled growth almost made it impossible for her business to survive: 
Participant two: The first big order that we received was a bit of an issue, because we had to find an FDA approved kitchen, which was very far away. I only had enough money to pay one employee, therefore me and her, had to drive a long way and work throughout the night in order to fulfill this big order for this big supermarket chain. It was very challenging but we made it; if we hadn't maybe my business would have never survived.

\section{Governmental Support}

The business owners interviewed discussed the fact that they had received very little support when they were starting their business, from their friends, the state, governmental entities like the FDA, and pretty much everybody around them except family. Most of the support received by these business owners turned out to be that of family around them that was willing to help them until the late hours of the night, and wake up early the next day in order to work together to start the business and run it later. This however is not necessarily the fault of the state, or the governmental entities in the state.

Most of these entrepreneurs did not even ask for a loan. They displayed fear in regards to the government or lending institutions. They felt as if asking for help, or asking for a loan was going to end up hurting them in the end, as if they would then owe something to someone that they could not pay back. They wanted to be free to do what they wanted with their money, and not have anybody tell them how to do things. 
Additionally, they assumed that banks, the state or government would not help them as much as they would others.

The experience of the one business owner that decided to ask for help, and had to deal with governmental agencies was not very positive, which in a way explains the reasons why the rest of the business owners, all wanted to spend as little time dealing with the government as possible. The perception that Latino business owners have of the government appears to be quite negative, here is what some of the business owners had to say about government:

Participant seven: I don't really feel like they [government] are helping you with their best interest in mind and selflessly, I always feel like there is something there, like a debt that I would later have to pay with increased interests.

Participant six: I was not interested in getting any government or outsiders involved in the process, I don't really trust them Participant five: el gobierno acá por lo que nos han contado se aprovecha de uno, más que todo cuando uno es Latino, entonces eso es mejor no llamarlos o involucrarlos. [Government here for what we've been told only takes advantage of people, especially when you are a Latino, so it is better not to call them or get them involved]

\section{Trust Issues - Discrimination (Perception)}

The business owners interviewed, all of them, discussed the idea of discrimination by several governmental entities that they believed would not treat them 
equally if asking for help, for a loan, or simply for support. However, the key word here is not discrimination, but belief. The business owners, all except for one, did not ask governmental agencies for help or support because they thought that they would not be treated with the same respect as other citizens.

One business owner in particular stated that she did not feel comfortable going to any governmental agency because she did not even trust the police, who according to her were hurting her business on a daily basis, participant three explained:

Participant three: Yo no busque ayuda con ninguna agencia del gobierno porque ni siquiera confió en los policías del pueblo. Estos policías me están arruinando el negocio, porque saben que la mayoría de mis clientes son Latinos entonces se paran afuera del mercado y esperan a que salgan mis clientes y les empiezan a pedir papeles y a molestarlos. Lamentablemente muchos de mis clientes no están aquí legalmente, entonces en vez de arriesgarse con la policía deciden no venir más a la tienda, y eso me hace mucho daño [I did not look for help with any governmental agency because I don't even trust the cops in my town. These cops are ruining my business, because they know that the majority of my clients are Latino so they stand outside the store and wait for my clients to go outside and begin asking for identification and bothering them. Unfortunately, many of my clients are not here legally, therefore instead of risking it with the cops they decide not to come to the store anymore, and that is hurting me a lot] 
In West Virginia however, it appears that out of the five major issues found, lack of trust or the perception of discrimination is the most pressing one. Lack of trust in the government and governmental agencies or programs, emerged as a common theme throughout this research. Most of the participants, all except one, discussed the fact that they would rather do things on their own than try and obtain any help from the government or any sort of outside agency. The one business owner, participant two, that discussed going to governmental agencies such as the SBA for help described her experience as a negative one and had this to say about the agency:

Participant two: I went to the SBA and other governmental agencies and got nothing but brochures of "how to's" but no actual help. I was not looking to collect brochures and information on how to start a business, I was looking for an individual that could actually guide me through the process or at least explain the steps necessary to start a business

Instead, the future business owner found herself with nothing but "Google" to help her start the business. However, her ordeal did not end there. Once she had finally gotten all of the bureaucratic steps out of the way she hit another wall, FDA approval.

Participant two: The FDA approval was probably one of the most difficult things in the process. I had to find a kitchen that was FDA approved in order to make my products. Before I did so they would call me up and tell me to just give up and not 
even try to go through with my business. They now call me and say: I guess we were wrong about not starting that business huh?

This particular business owner is now very successful with her business, but if she had not had the tenacity to continue to move forward, and had simply decided to listen to the FDA and give up on her business, she would have passed up a major opportunity to succeed.

\section{Market Demand}

The Latino businesses in West Virginia that are succeeding and thriving are those businesses that do not aim for a Latino market. One business owner stated: "I really don't have any problems with my business. I choose my clients. I would not change anything, and I did not get hit by the crisis so I'm not encountering any problems right now"

The businesses that do cater to Latinos however, are hurting and on the brink of failure. Largely because the Latino population in West Virginia is the smallest in the entire country and people searching for Latino products represent a small portion of the population. Still, entrepreneurs tend to create what they know, and prospective Latino business owners are more likely to start businesses based on familiar Latino market demand. Participant one, who owns a catering service, said it best:

Participant one: I started my business in Mediterranean food catering because it's what I do, I cook, I love cooking and it is my passion, but I do not have, and never have had any Latino customers since I started my business. That is not 
who I cook for. There are very few Latinos here and that is one of the reasons why I do not cook Latino food, Mediterranean food provides me with a better chance of succeeding

Now that the major findings of the study have been identified, a detailed discussion of what they mean to West Virginia and Latinos in the state follows. 


\section{CHAPTER 5 - DISCUSSION}

I began this study with the notion that funding was going to be one of the most, if not the most, pressing issue why Latino business owners would not start businesses in the state of West Virginia. And while it was cited to be a small problem by some of the business owners, it was definitely not found to be a pressing issue. Five critical issues and reasons why Latinos in West Virginia are not starting businesses at the same rate as they are in other states have been identified. These five issues are: Sense of Community; Expertise Level; Governmental Support; Trust issues - Discrimination (Perception); and Market Demand and they will each be discussed in turn.

\section{Sense of Community}

This is a problem because several studies (Portes and Zhou, 1994; Zarrugh, 2007) have shown that support from other Latino entrepreneurs is very important to succeed, especially in a tough economy. Business owners can share experiences, issues, problems, and solutions in order to make each other better and thrive as a community. If this type of community support does not happen with Latino business owners in West Virginia, and the businesses see each other as competition, then working together becomes impossible and the benefits of peer support are not realized.

Additionally, a lack of sense of community affects the potential creation of an ethnic enclave in West Virginia, which would make it less appealing for other Latinos. This creates a cycle in which the lack of a current Latino community in the state makes it more difficult for more Latinos to come and increase the Latino community in West 
Virginia. Therefore a lack of sense of community negatively affects the possibility for Latino entrepreneurial ventures to increase in the state.

\section{Expertise Level}

Even though it proved to be an issue that many business owners seemed to overcome, it was still a big issue The level of expertise of an entrepreneur is critical, especially in the case of sole proprietors, like half of the participants interviewed are, where an individual is basically responsible for every single operational aspect of a business. Not having a certain level of expertise can be highly risky and it could potentially harm the future of a good business if help is not sought. This leads us to the next biggest issue Latino entrepreneurs deal with in West Virginia, lack of governmental support.

\section{Governmental Support}

Governmental support was found to be non-existent regarding the Latino business owners interviewed. This was found to be more a desire of the entrepreneurs than a fault of the government. Latino entrepreneurs in West Virginia were very clear about not wanting government support in their business ventures. They do not seem to trust the government in any way, and have chosen that their businesses are better off without its involvement.

This however, is a major issue and misconception. Latino individuals starting a business in West Virginia need to understand that there are many minority oriented programs for them to take advantage of, and that the government is more than willing to help them with their businesses just as they would anybody else. This brings us to the 
fourth biggest issue with Latino entrepreneurs in West Virginia: Lack of trust and perception of discrimination.

\section{Trust Issues - Discrimination (Perception)}

Latino business owners described the fact that they did not asked for support because they thought that they were going to be taken advantage of by government and other entities. They believe that the government is not going to help them with their best interests in mind, when in reality the government would greatly benefit from more Latino businesses being started in the state. This lack of trust is a very big issue because unless government figures out a way to convince Latinos in West Virginia that they are there to work with them, and not against them, it is going to be very difficult to attract more Latino entrepreneurs to the state.

This perception of discrimination, which would be a direct product of lack of trust in governmental entities, can very easily become fear of governmental entities. This creates a very big issue for the state of West Virginia, since the idea that potential entrepreneurs do not seek for help because of fear or lack of trust would make it very difficult for the state to stimulate growth in this particular sector.

\section{Market Demand}

The businesses succeeding in the state are those that differ from the norm, and the norm is Latino groceries and restaurants that cater to Latinos and the Latino market. Therefore, in order to increase Latino businesses in the state either the number of Latinos in the state has to grow, or Latino business owners have to become savvier and start businesses that are not necessarily aimed at the Latino market. 
Since West Virginia is not a state that provides a steady, or even existent Latino market, Latinos wanting to start their businesses in the state, have to start adapting their mentality to the reality of their context, and serve the market available. The lack of Latino ethnic enclave in the state keeps it from developing a more ethnic economy, which in turn forces potential Latino to look for other markets in order to succeed.

\section{Latino business owners in WV}

Latino business owners in the state of West Virginia are quite diverse. They come from different countries, education, immigration, and work backgrounds. There is however a pattern that this particular research has found between some of the Latino business owners in the state. The majority of the participants interviewed were women, usually between 40 and 60 years old, that came to the U.S when they were much younger, had at least a high school degree, have been married and have children. Most of them are self-declared Catholics, and opened up their businesses with their own savings without asking for a loan. In deciding how to start a business, they either worked at a business where they did the job they do now, their families had a history of starting businesses, or they were motivated by their friends and family to do so. And the motivation for starting such business was linked to financial autonomy and freedom. It has been found in both traditional and nontraditional destinations, that entrepreneurship is a viable means to those ends (Portes \& Zhou, 1994; Zarrugh, 2007).

The most surprising fact about these entrepreneurs however, has to do with the way in which they funded their business. At the beginning of this study, credit accessibility was hypothesized to be one of the biggest, if not the biggest, issues that 
prospective Latino entrepreneurs could run into when trying to start a business. However, as it has been demonstrated by this research, Latino entrepreneurs in West Virginia do not even try to obtain a loan or obtain financial aid from any type of organization. Instead, they rely on personal savings, or family and friends that are willing to help out with an investment. Most of the Latino businesses in West Virginia are restaurants (catering), grocery stores, or other, which includes [condiments] manufacturing and translation and beauty services.

Regarding the challenges described by the participants in the state of West Virginia, the idea of fear and lack of trust stood out the most. Latino entrepreneurs, unlike other entrepreneurs, are not comfortable going to state or financial entities for help. They do not trust that they will be treated equally, and fear that they may put themselves in harm's way if they decide to try and ask for help with their businesses. Some of the participants also described issues dealing with racism, discussing the fact that the police would target their business and their clients, in order to try and catch some illegal aliens in the easiest way possible. Racism however, was not a major issue to most of the Latino business owners interviewed. The participants that have been in the country for a longer time period and spoke fluent English, mentioned the issue of racism far less than those that had been here for a shorter amount of time, or spoke bad or no English. As shown by previous research, strained racial/ethnic relations occur in both traditional (Bonacich 1973; Light \& Gold 2000) and nontraditional destinations (Mannon \& Smith 2008; Putnam 2000).

Language seemed to be a difficult area to assess. Three of the participants asked to be interviewed in Spanish, while the other five were comfortable enough with 
their English to be interviewed in that language. Coincidentally, the individuals that asked to be interviewed in Spanish were the ones that were having the biggest issues with their businesses, and the ones that were considering closure as an option. While the participants that were interviewed in English, described their businesses as very stable and profitable, and had no plans to close their businesses any time soon.

The prosperity of Latino business owners that speak fluent English as opposed to the lack of prosperity experienced by Latino business owners that still, after years of owning a business in the state, do not speak English is a direct result of the lack of ethnic enclave in the state, and the lack of acculturation by these business owners. At the beginning of this paper the concepts of ethnic enclave and acculturation were introduced as probable obstacles for Latino business owners in the United States, and in West Virginia. This study has confirmed that they are directly related to one another. A Latino business owner can potentially decide to go through a mediocre or even nonexistent acculturation process, and still be successful if an ethnic enclave exists in the community in which he or she lives, because this individual can potentially shield him or herself from the "outside" world, and hide inside the enclave. At the same time a community that lacks an ethnic enclave forces a Latino business owner to go through a good and solid acculturation process in order to become a part of society and the community. If the person chooses not to go through the process, and the ethnic enclave does not exist, then the chances of that business being successful are exponentially reduced. 


\section{Thriving Environment Development}

This research has provided a clear insight into what the major variables for Latino success in the United States are. Some of these variables are definite reasons why Latinos thrive in a certain environment, such as an ethnic enclave and geographic location, while other reasons are more potential causes of such success, like warm weather and a large labor force. The following model, Figure 11, demonstrates a concise set of variables, both definite and potential, that are major reasons for Latino success in the United States.

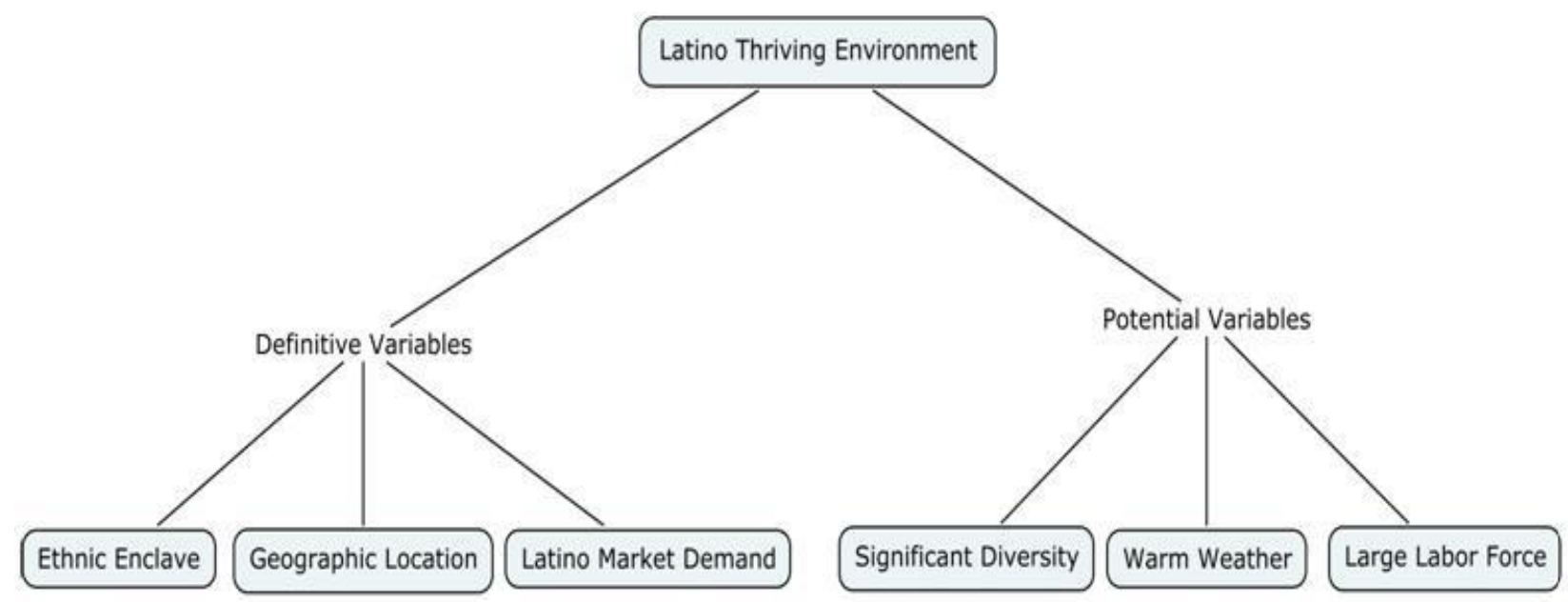

Figure 11. Latino Thriving Environment Model

While these variables are quite widespread across states where Latinos thrive, they cannot and should not be used as definite reasons why Latinos succeed, and the absence of such variables are not necessarily a cause for lack of success. The definite variables however, are much clearer when it comes to having an impact both positive and/or negative in regards to Latino population in a certain state. The potential variables 
on the other hand, are more intangible and are present in a majority of states where Latinos thrive, but not in all of them.

This model is important because it could potentially provide a pathway for West Virginia to begin molding its state towards a more Latino friendly community. Things like weather and geographic location cannot be changed, but other factors such Latino market demand, an ethnic enclave, and a more diversity-minded attitude might something that can begin to grow gradually in the state, especially near the border with Northern Virginia and Washington, D.C where these three aspects can be increased by simply attracting some of the individuals living in those states into West Virginia.

\section{Positive Aspects}

Even though several pressing issues were found, and many obstacles surround Latino business owners in West Virginia, there were also positive aspects for owning a business in the state. Several individuals expressed their joy and happiness in being able to come and go as they please without having to answer to a "boss" or power figure. The business owners that claimed to be doing well defined themselves as successful and optimistic towards what the future brings. In fact the two most positive aspects of a Latino owning a business in West Virginia are autonomy and optimism. These will be further discussed in turn.

\section{Autonomy}

All but one of the business owners interviewed stated that one of the reasons why they started their business was because it provided them with autonomy. This autonomy was described in many different ways, participants discussed the fact that 
they got to spend more time with family, they were glad to be their own boss, and do what they love and work with passion every day. The idea of being autonomous, more than the idea of making lots of money and economic success, was the main reason why these business owners started their business.

The fact that they get to do the thing they love, with freedom and passion, is worth more than money, and many of them work to make enough to live well, but are not looking to become rich. When discussing the idea of economic success participant one said:

Participant one: It is not about making money; it is about maintaining control of your business. If there is one piece of advice I would give people starting their business it is to keep control of their business. That is the best way to provide a good service and a good product. And if you grow too much, you lose control of your business. I have decided not to grow too much, but I only have two children. If I had more I would have probably try to grow a bit more

This excerpt from one of the interviews, shows that this particular business owner was not looking to become rich, she was just looking to provide a comfortable living for her two children and that's it. But the most important thing for her was autonomy, because that was the only way in which she could keep control of the business and grow when and where she decided to grow. 


\section{Optimism}

The second most common outcome of this particular study is the fact that business owners, for the most part, appeared to be very optimistic. A minority of the business owners interviewed (those who aim for a Latino market), did not seem to be very optimistic about their future or their business. However, the business owners that described themselves as successful displayed great optimism. These are some of the optimistic statements from the business owners:

Participant eight: "I think I am going to keep my business for another 10 years or so, and then I will just close it down, retire, and enjoy the fruit of my hard work"

Participant one: "I have been blessed, I have a great business, great support, and the ability to work by myself, I would not change a thing"

Participant seven: "I have had absolutely no obstacles whatsoever, I have had a great experience with my business and would recommend it to anybody that is looking to start one of their own"

Optimism was directly related with the success of the business owner, but even in situations where the business was not doing very well, the business owners, all except for one, described themselves as "hopeful" things would change and get better.

\section{Implications}

A SWOT analysis is a very powerful tool that can be used in many different ways. It can be carried out for a product, place, industry or person. It involves specifying the 

weaknesses, opportunities, and threats that Latino business owners face in the country.

\section{Table 11}

\section{Latino Business Owners SWOT Analysis (Arcila, 2012)}

\begin{tabular}{|c|c|}
\hline $\begin{array}{l}\text { Strengths } \\
\text { Hispanic-owned businesses in the United States have } \\
\text { increased dramatically over the last few years. According } \\
\text { to the U.S Census Bureau Hispanic businesses have } \\
\text { increased by around } 43.7 \text { percent to } 2.3 \text { million, which is } \\
\text { more than twice the national rate of } 18.0 \text { percent } \\
\text { between } 2002 \text { and } 2007 \text { (U.S Census Bureau, 2010). } \\
\text { According to the U.S Census Bureau "Hispanic owned } \\
\text { businesses generated } \$ 345.2 \text { billion in sales in } 2007 \text {, up } \\
55 \text { percent compared with } 2002 \text { " and "The number of } \\
\text { Hispanic-owned businesses with receipts of } \$ 1 \text { million or } \\
\text { more increased } 51.6 \text { percent - from } 29,168 \text { to } 44,206 \\
\text { businesses between } 2002 \text { and } 2007 \text { " (U.S Census } \\
\text { Bureau, 2010, p. 3). }\end{array}$ & $\begin{array}{l}\text { Weaknesses } \\
\text { 93\% of Hispanics reported operating their businesses as } \\
\text { sole proprietors, and thus might lack the time and/or } \\
\text { resources to seek the necessary and correct information } \\
\text { to improve their businesses (Triana, et al., 1984). } \\
\text { Mexican business ownership studies in particular, have } \\
\text { languished due to perceptions regarding low education } \\
\text { levels and the very low self-employment rates amongst } \\
\text { Mexicans reported in current census data (Tienda \& } \\
\text { Raijman, 2004). }\end{array}$ \\
\hline $\begin{array}{l}\text { Opportunities } \\
\text { About one third ( } 30.0 \text { percent) of Hispanic-owned } \\
\text { businesses operated in three different industries: } \\
\text { construction, repair and maintenance, and personal } \\
\text { laundry (U.S Census Bureau, 2010). }\end{array}$ & $\begin{array}{l}\text { Threats } \\
\text { Today a company's values not only have to be consistent } \\
\text { within the company but also with its environment, taking } \\
\text { into consideration the entire chain, from suppliers to } \\
\text { customers (Enz, et al., 1993). }\end{array}$ \\
\hline $\begin{array}{l}\text { According to Fairlie \& Woodruff nearly a quarter of } \\
\text { Mexico's workforce is self-employed, and roughly } 10 \% \text { of } \\
\text { individuals born in Mexico now reside in the United } \\
\text { States(2006), which may be an indication of what can be } \\
\text { expected from Latino immigrants. } \\
\text { The Latino population in the United States is growing } \\
\text { exponentially, and looking to move from being } \\
\text { considered a "labor only" workforce to a more } \\
\text { entrepreneurial one (Zarrugh, 2007). }\end{array}$ & $\begin{array}{l}\text { Though society has, for the most part, reached a point } \\
\text { where globalization is not only accepted but welcomed, } \\
\text { discrimination persists especially with regard to support } \\
\text { from investors and customers (Enz, et al., 1993). } \\
\text { According to the Pew Hispanic Center, the illegal } \\
\text { immigrant population of the United States in } 2008 \text { was } \\
\text { estimated to be about } 11 \text { million people, down from } 12.5 \\
\text { million people in } 2007 \text {. In } 2005,56 \% \text { of illegal } \\
\text { immigrants were from Mexico; } 22 \% \text { were from other Latin } \\
\text { American countries, primarily from Central America; } \\
\text { and13\% were from Asia (Passel,2005) }\end{array}$ \\
\hline
\end{tabular}




\section{Conclusion}

This study suggests a need for future cross-cultural development between Latinos and other demographics in West Virginia in order to succeed. It is clear that without collaboration with other cultures and demographics the idea of increasing Latino businesses to the state, and appealing more Latinos to West Virginia is an uphill battle. This study set out to answer two major research questions, the first research question was:

Why are there so few Latino Entrepreneurs in West Virginia?

There are two major reasons why there are so few Latino entrepreneurs in West Virginia, the first reason is language barriers and the acculturation process. As it was stated throughout the study, language plays a critical role in the acculturation process of a Latino in the United States. This process has proven to be of critical importance Latino owned businesses, as the business owners that displayed excellent English language skills stated that their business was currently thriving. While the business owners that showed to have intermediate or basic English skills, had struggling businesses.

Language and the acculturation process is critical in any state that Latinos may want to start their businesses in, however in a state like West Virginia with such a low Latino population a business owner cannot allow him or herself the option of not speaking good English as it is critical to relate to suppliers and customers. In other states where there is a higher Latino population, business owners could potentially be successful without going through a good acculturation process or speaking good English, but a strong ethnic enclave is necessary for that to happen. 
This brings us to the second reason why there are so few Latino entrepreneurs in West Virginia, a lack of ethnic enclave. An ethnic enclave is that Latino community that allows newcomers to feel at home, to feel comfortable, and to be able to socialize without being subject to any sort of adaptation trauma when moving to a new country. In other states, like California, Texas, Florida, and New Mexico the ethnic enclaves are very strong, therefore creating ethnic economies and allowing for more Latino entrepreneurial ventures to be created. In West Virginia however, it is very difficult for these Latino businesses to be created because an ethnic economy is not present, and there is no ethnic enclave for this demographic, which translates into a very small market for potential Latino aimed businesses.

Therefore bad language skills, a poor acculturation process, and a lack of ethnic enclave for Latinos in West Virginia were found to be the most pressing reasons why there are so few Latino entrepreneurs in the state.

The second research question this study aimed to answer was:

What are the entrepreneurial issues identified by Latino business owners in West Virginia?

The main portion of the discussion of this paper was aimed towards understanding the entrepreneurial issues identified by Latino business owners in West Virginia. The five main issues identified were:

- Sense of Community

- Expertise Level

- Governmental Support

- Trust issues - Discrimination (Perception) 


\section{- Market Demand}

The following figure (Figure 12) summarizes the way in which these five issues relate to each other, and demonstrates the importance of figuring out how to alleviate each one of these issues:

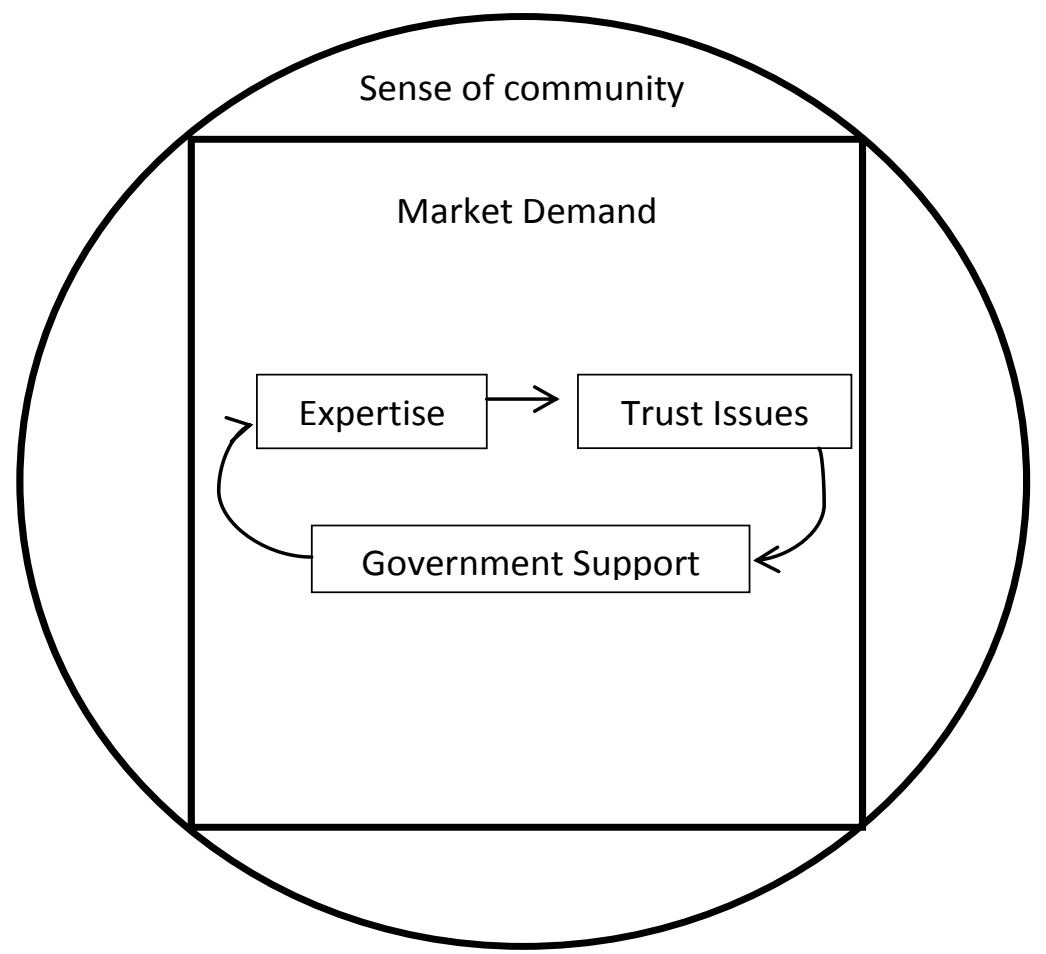

Figure 12 - Entrepreneurial Issues Identified by Latinos in W.V

The five issues identified by Latinos in West Virginia coexist together, as they are all a part of the sense of community or lack of community in the state, which then creates the environment of market demand, or lack of market demand, and then a cycle is created between trust issues, governmental support and expertise. Latino entrepreneur's fear, demonstrated trust issues meaning they do not seek help and support from the government, which in turn hurts their levels of expertise in running and starting a successful business. Moreover, those trust issues could potentially be 
mitigated by more knowledge and a higher level of expertise, but instead, the lack of expertise may be one of the causes of their trust issues.

In addition to the five major issues identified, one of the most interesting finds of this study had to do with the fact that funding was NOT found to be a pressing issue for Latino entrepreneurs in West Virginia. Work done previously, in other regions of the country, has found funding, discrimination, racism, and lack of education as the main reasons why Latino entrepreneurship was not as developed as in other states. Funding was mentioned as an issue by some business owners, but most of the interviewees were quite clear when it came to asking for loans or looking for monetary help. In fact, when asked if she had asked for a loan, participant six stated:

"No, I was very sure of what I was doing; I never wanted to find any funding because I would have to spend my entire life paying for it" This is a major finding because all of the similar previous studies done in other states found funding to be one of the most important and critical reasons why Latinos could not start their businesses.

\section{Recommendations and Future Research}

Although the Latino population in the United States is becoming an incredibly strong and valuable asset to the American economy, the state of West Virginia has yet to capitalize on this trend. It should be possible to bring in more Latino businesses to the state if West Virginia fully embraces Latino businesses as a path to economic diversity, and develops effective support structures to expand the Latino community as well as Latino owned businesses. 
Latinos are an adaptable demographic that would only need a small push to start their businesses in West Virginia. The counties of Jefferson, Morgan, and Berkley are the key to begin this expansion of Latinos and Latino owned businesses in West Virginia. As they are nearby Washington D.C and northern Virginia, where the Latino population is quite big and could use a way to expand into different areas. Assumptions have been made from a very small sample of West Virginia entrepreneurs. It might be good for future research to repeat the study in Maryland and Virginia as a test of those assumptions.

\section{Governmental support}

Governmental support is critical for Latino business owners that want to start their businesses in West Virginia. However, establishing programs for minorities, and allowing funding for potential Latino business owners may not be enough. This research found that the biggest issue regarding lack of governmental support has to do with lack of trust and fear from Latinos towards the government. Latino business owners appear to have a great lack of trust in any sort of governmental agency or program which makes it even more difficult for the state to help these individuals. Fear and distrust were bigger issues than either inadequate funding or lack of governmental support programs.

Better communication channels might serve as a first step toward regaining the trust that has been lost. One way to do might be to establish a peer-to-peer mentoring program that would pair Latino business owners with successful entrepreneurs in the state that could show them how things work. This could possibly take the form of an 
entrepreneurial forum sponsored by the state, where successful entrepreneurs discuss their experiences (successes and failures) with individuals looking to start their businesses.

The government needs to become more available for these individuals, it needs to become easier to contact, and it needs to start providing real help to Latinos in West Virginia. More personalized help is needed where the business owner can potentially have a government agent assigned to their business venture for specific support and guidance. Once Latino business owners have a positive experience with governmental agencies supporting their work, the word-of-mouth will eventually bring in more Latino business owners to ask for help, funds, and overall advice to start a business.

Another way in which peer mentoring for Latino entrepreneurs could be facilitated is through the creation of a state supported website that provides general advice on how to start and create a successful business, specifically for Latinos. This website could potentially help Latinos find better information when starting a business, and increase their possibilities to succeed. The program, which would need to be in Spanish and English, could provide Latinos with a pseudo step by step process of what is needed in general business creation. Taking into account the fact that the majority of Latino businesses orbit around a small number of industries, the website could have specific paths for those trying to start a restaurant or a grocery store, and have more general paths for those trying to offer a service, such as a Laundromat or a beauty salon.

This website would be of great help for Latinos trying to start a business in the state of West Virginia, as the Internet has become a readily available commodity for most people, and it can be easily accessed by thousands of people. The website should 
also contain contact information where the entrepreneurs can call, like a support line, and ask for further advice and help. Additionally, a list of minority funding programs, and Latino aids provided by the state should be provided. This way, Latinos would be more exposed to the services and programs available to them in West Virginia, the government would be proactively helping these individuals, and the fear and lack of trust may begin to go away gradually.

The government could also take a cue from the West Virginia State University Extension Service's Economic Development Center in Charleston, which recently introduced a new program called BBASE. BBASE, which is the acronym for Black Business Association Supporting Entrepreneurs, was started out of an interesting exchange between Sandra Moss, a business development agent at the center, and a client who simply asked her: "Do you know a black architect?" (Higgins, 2013). She did not, and even though she figured out a way to find a black architect, she realized that maybe having a list of black entrepreneurs and creating a group specific to that particular race would be a positive thing. Ms. Moss, realized that "If we can get those businesses together and have them help each other, to mentor that one aspect that they don't' know about, then that's a helping hand," she said. "We're going to stimulate the economy, and that's one more business that's going to help West Virginia grow" (Higgins, 2013).

This association might be used as an example and extended into other demographic groups such as Latinos. If Latinos could have an organization that caters directly to them, and is created for them, then the possibilities of seeing more Latino businesses in West Virginia might increase exponentially. Additionally, the idea of 
mentoring, which is such powerful tool, could benefit not only current business owners, but also the Latino youth that may be looking for that extra push before jumping in to start a business. Ms. Moss also discussed the fact that "There are so many creative minds out there, and they don't know where to go. They don't know how to do it," she said. "And so if we can set up this community of people who work together we can stimulate a younger generation to consider starting small businesses" (Higgins, 2013). These types of associations could be very powerful and helpful to minorities, especially when a perception of discrimination is present and the fear of starting a business tends to discourage so many from taking that leap of faith.

\section{Future Research}

This particular study was created to explore and understand why are there so few Latino Entrepreneurs in West Virginia, and to discover what the entrepreneurial issues identified by Latino business owners in the state are. However, the potential of future research that comes with this study is enormous. Future studies could focus on other demographics, using this study as a basis of comparison; for example the Asian demographic could be examined, which is another group that struggles in the state of West Virginia but thrives in other areas. Additional research could expand into other geographic regions or states, examining Latino entrepreneurship in non-traditional Latino destinations like Mississippi or Kentucky. Furthermore, the study could be adapted to look at other economic behavior of Latinos in West Virginia or other states, by investigating Latinos that work primarily labor oriented jobs, in order to understand the rationale behind their employment choices, and see if the acculturation process and 
language abilities play role there are well. Lastly, a study could also be created to examine Latino experiences of international students that came to West Virginia for academic purposes, in order to understand their journey and whether the acculturation process of these individuals is different than those that came to the state for other reasons.

Additionally, future applications could also focus on creating a document or website that begins to address the issues found for Latino entrepreneurs in West Virginia. That way these future entrepreneurs would be able to find more available information in regards to what they need to do in order to start a business, and what steps need to be followed in order to do so successfully. This work should be done with a partnership with the SBDC (Small Business Development Center) of West Virginia since it would provide a much wider range and the possibility of reaching a wider audience. 


\section{BIBLIOGRAPHY}

Asala, C. (2010). Job Mentality Versus Business Ownership Mentality. Resources for Entrepreneurs. Retrieved from http://www.gaebler.com/Job-Mentality-VersusBusiness-Ownership-Mentality.htm

Aud, S., Fox, M. A., \& KewalRamani, A. (2012). Status and Trends in the Education of Racial and Ethnic Groups. U.S Department of Education. Retrieved from http://nces.ed.gov/pubs2010/2010015.pdf

Baron, R. (2008). The Role of Affect in the Entrepreneurial Process. Academy of Management Review, 33(2), 329-340. Retrieved from http://www.business.uconn.edu/ccei/files/IDEAawards/Baron_AMR.pdf

Bar-On, R. (2010). Emotional Quotient Inventory (EQ-I). Retrieved from http://www.psychologyafrica.com/pdf/Abstracts_pdf/Emotional\%20Quotient\%20In ventory\%20(EQ-I\%AE).pdf

Baum, R., \& Locke, E. (2003). The Relationship of Entrepreneurial Traits, Skill, and Motivation to Subsequent Venture Growth. American Psychological Association, 587-598. Retrieved from

http://ad4tq3gq5x.scholar.serialssolutions.com/?sid=google\&auinit=JR\&aulast=B aum\&atitle=The+relationship+of+entrepreneurial+traits,+skill,+and+motivation+to +subsequent+venture+growth.\&id=doi:10.1037/0021-

9010.89.4.587\&title=Journal+of+applied+psychology \& $v$

Bonacich, E. (1973). "A Theory of Middleman Minorities." American Sociological Review 38(Oct):583-594.

Bonacich,E. (1987). "Making It" in America: A Social Evaluation of the Ethics of Immigrant Entrepreneurship. Sociological Perspectives - The Ethnic Economy, Vol. 30(No. 4), pp. 446-466.

Boren, A. (2010). Emotional Intelligence: The Secret of Successful Entrepreneurship? Faculty Publications - University of Nebraska. Retrieved from http://digitalcommons.unl.edu/cgi/viewcontent.cgi?article=1054\&context=aglecfac pub 
Braverman, S. (2011). Americans Like People Who Speak Like They Do. In H. I. Inc. (Ed.): Harris Poll.

Britannica Academic Edition. (2012). Success. Retrieved from Britannica Academic Edition: http://www.britannica.com/bps/dictionary?query=success

CED. (2010). CED Council for Entrepreneurial Development Start Something. Retrieved from Support Organizations:

http://www.cednc.org/content/support+organizations/10295

Censky, A. (2011, May 26). Coal 'ghost towns' loom in West Virginia. CNN Money.

Creswell, JW. (1998). Qualitative Inquiry and Research Design Choosing Among Five Traditions. Thousand Oaks, CA: Sage Publications.

Cummings, S. (1980). Self-help in Urban America Patterns of Minority business enterprise. New York.

Dabson, B. (2001). Supporting Rural Entrepreneurship. Paper presented at the Rural Conferences.

Doh, S., \& Zolnik, E. J. (2011). Social capital and entrepreneurship: An exploratory Analysis. African Journal of Business Management, 4961-4975.

Ebner, A. (2005). Entrepreneurship and economic development: From classical political economy to economic sociology. Journal of Economic Studies, 256-274. Retrieved from http://www.emeraldinsight.com/journals.htm?articleid=1514980\&show=abstract

Enz, C. A., Marc, J. D., \& Catherine, M. D. (1993). The Value Orientations of Minority and Non-Minority Small Business Owners. Entrepreneurship: Theory \& Practice, Vol. 15(No. 1), P. 23-35.

Evans, M. D. R. (1989). Immigrant Entrepreneurship: Effects of Ethnic Market Size and Isolated Labor Pool,. American Sociological Review Vol. 54(No. 6 ), pp. 950-962.

Ewing Marion Kauffman Foundation. (2010). 2010 State New Economy Index.

Fairlie, R., \& Woodruff, C. (2006). Mexican Entrepreneurship: A Comparison of SelfEmployment in Mexico and the United States. Institute for the Study of Labor. 
Fortunato, M., \& Alter, T. (2011). The Individual-Institutional-Opportunity Nexus: An Integrated Framework for Analyzing Entrepreneurship Development. [Article 6]. Entrepreneurship Research Journal, Vol. 1(Issue 1).

Fox News Latino. (2012, March 22). West Virginia's Latino Mini Boom. Retrieved from Fox News.

Fram, A. (2010, May 20). Hispanics Face Most Discrimination In U.S. (POLL). Huffington Post. Retrieved from http://www.huffingtonpost.com/2010/05/21/hispanics-face-mostdiscr_n_583538.html

Gale Learning. (2003). Encyclopedia of Small Business. Independence, Kentucky: Gale. Goldsby, M. G., Kuratko, D. F., \& Bishop, J. W. (2005). Entrepreneurship and Fitness: An Examination of Rigorous Exercise and Goal Attainment among Small Business Owners. Journal of Small Business Management, 78-92. Retrieved from

http://onlinelibrary.wiley.com/doi/10.1111/j.1540-627X.2004.00126.x/pdf

Hammond, G.W (2011). West Virginia Economic Outlook 2012. WVU Research Corporation. Retreived from http://be.wvu.edu/bber/pdfs/BBER-2011-14.pdf

Hanft, A. (2003, October). The Inevitable Rise of the Entrepreneur. Inc. Magazine. Hernández-León, Rubén and Víctor Zúñiga. (2000). "Making Carpet by the Mile: The Emergence of a Mexican Immigrant Community in an Industrial Region of the U.S. Historic South." Social Science Quarterly 81(1):49-66.

Humphrey, Albert (December 2005). "SWOT Analysis for Management Consulting". SRI Alumni Newsletter (SRI International).

Independent Statistics and Analysis. (2009). West Virginia Quick Facts, from http://www.eia.gov/state/state-energy-profiles.cfm?sid=WV

Higgins, S. (2013, January 25). New group supports african american entrepreneurs. Retrieved from http://www.wvpubcast.org/newsarticle.aspx?id=28360

Latinvision Entrepreneurs. (2012). Hispanic Entrepreneurs. New York: LatinVision Media. Retrieved from http://www.latinvision.com/entrepreneur.pdf

Lewis-Fernández, R., Das, A. K., Alfonso, C., Weissman, M. M., \& Olfson, M. (2005). 
Depression in US Hispanics: Diagnostic and Management Considerations in Family Practice. Journal of the American Board of Family Medicine, 282-296. Retrieved from http://www.jabfm.org/content/18/4/282.full\#sec-2

Light, I. (1972). Ethnic Entrepreneurs in America: Business and Welfare among Chinese, Japanese, and Blacks. Berkeley: University of California Press.

Light, Ivan \& Gold, S. (2000). Ethnic Economies. New York: Academic Press.

Light, I., \& Rosenstein, C. (1995). Race, ethnicity, and Entrepreneurship in Urban America.

Llorente, E. (2011, March 03). Fox News Latino. Retrieved 2011, from Fox News.

Mannon, Susan E. and Smith, R. (2008) "Latino Fault Lines: Intra-Latino Divisions and Tension in Northern Utah." Paper presented at the annual meeting of the Pacific Sociological Association, Portland, Oregon.

McFall, B. (1998). Personal Resource Systems Management: A Proposal for Interactive Practice. Virginia Tech. Retrieved from http://scholar.lib.vt.edu/theses/available/etd-42898-171311/unrestricted/etd.pdf

McFall, B. (2006). Personal Resource Systems Matrix and Model (PRSM). Retrieved from Knowledge Management for the Human Sciences:

http://km.kon.org/personal-resource-systems-model.html

McCracken, G. (1988). The long interview. Newbury Park, CA: Sage.

Medina, G. (2012, April 4). Latinos Seeking Liquor Licences Charge Discrimination. Voices of NY. Retrieved from http://voicesofny.org/2012/04/latinos-seekingliquor-licences-charge-discrimination/

Mendes, F. N. (2009). About One in Six U.S. Adults Are Without Health Insurance. Gallup Wellbeing. Retrieved from http://www.gallup.com/poll/121820/one-sixadults-without-health-insurance.aspx

Passel, Jeffrey (2005, March 21). "Estimates of the Size and Characteristics of the Undocumented Population" (PDF). Pew Hispanic Center.

Perez, M. (2011, June 18). What should Latinos do in the hot weather? Examiner.com.

Portes, Alejandro and Min Zhou. 1994. "Should Immigrants Assimilate?" Public Interest. Summer issue no. 116. 
Putnam, R. (2000). Bowling Alone: The Collapse and Revival of American Community. New York: Touchstone.

Reimers, F. (1999). Education and Poverty in Latin America. ReVista - Harvard Review of Latin America. Retrieved from http://www.drclas.harvard.edu/revista/articles/view/491

Saenz, Rogelio. 2004. "Latinos and theChanging "Face of America." In the American People edited by Reynols Farley and John Haaga. New York: Russell Sage Foundation.

Samli, C. (2009). Personal Characteristics of Entrepreneurs. International Entrepreneurship, 27-33. Retrieved from http://www.springerlink.com/content/?k=doi\%3a(\%2210.1007\%2F978-0-38788597-1_4\%22)\&MUD=MP

Scales, J., Wennerstrom, A., Richard, D., \& Wu, S. (2006). Language Learners ' Perceptions of Accent. Teachers of English to Speakers of Other Languages, Inc. (TESOL), Vol. 40, pp. 715-738. Retrieved from http://www.jstor.org/stable/40264305

Shah, D. (2009, September 21). 12 Facts About Entrepreneurs That Will Likely Surprise You. OnStartups. Retrieved from http://onstartups.com/tabid/3339/bid/10561/12-Facts-About-Entrepreneurs-ThatWill-Likely-Surprise-You.aspx

Shane, S. (2008, April 28). Startup Failure Rates - The Real Numbers. Small Business Trends. Retrieved from http://smallbiztrends.com/2008/04/startup-failurerates.html

Shane, S. (2009, July 17). You're the Boss. THe New York Times. Retrieved from http://boss.blogs.nytimes.com/2009/07/15/failure-is-a-constant-inentrepreneurship/

Shinnar, R. S., \& Young, C. A. (2008). Hispanic Immigrant Entrepreneurs in the Las Vegas Metropolitan Area: Motivations for Entry into and Outcomes of SelfEmployment. Journal of Small Business Management, Vol. 46(No. 2), P. 242262. 
Small Business Association - SBA. (2008), from http://www.sba.gov

Smith, R. (2010). Latino Entrepreneurs in Nontraditional Destinations The Case of Northern Utah. Dissertation.

Spener, D., \& Bean, F. D. (1999). Self-employment Concentration and Earnings among Mexican Immigrants in the United States. Social Forces, Vol. 3(77), 1021-1047.

Suro, R., \& Singer, A. (2002). Latino Growth in Metropolitan America: Changing Patterns, New Locations. Brookings Institution Washington, .

Tienda, M., \& Raijman, R. (2004). Promoting Hispanic Immigrant Entrepreneurship in Chicago. Journal of Developmental Entrepreneurship, Vol. 9(No. 1).

Torres, G., Pelham, B., \& Crabtree, S. (2009). Half of New Latino Immigrants to U.S. Send Money Abroad. Gallup Economy. Retrieved from http://www.gallup.com/poll/123140/half-new-latino-immigrants-send-moneyabroad.aspx

Torres, L., \& Rollock, D. (2009). Psychological Impact of Negotiating Two Cultures: Latino Coping and Self-Esteem. Marquette University.

Triana, A. R., Welsch, H. P., \& Young, E. C. (1984). Information Search Patterns Among Hispanic Entrepreneurs. Journal of Small Business Management, Vol. 22.

U.S Census Bureau. (2009). West Virginia Quickfacts Retrieved September, 2010, from http://quickfacts.census.gov/qfd/states/54000.html

U.S Census Bureau. (2010). Hispanic-Owned Businesses Increase at More than Double the National Rate Retrieved October 6th, 2010, from http://www.census.gov/newsroom/releases/archives/business_ownership/cb10145.html

U.S Census Bureau. (2007). Survey of Business Owners - Hispanic-Owned Firms: 2007. Washington D.C: U.S Census Bureau.

U.S Census Bureau. (2010). Census Bureau Reports Hispanic-Owned Businesses Increase at More Than Double the National Rate. Washington D.C: U.S Census Bureau. 
U.S Census Bureau. (2010). The Hispanic Population. Washington, D.C: U.S Census Bureau.

United States Department of Labor. (2010). Overview of BLS Statistics on Unemployment, from http://www.bls.gov/bls/unemployment.htm

Verdaguer, M. a. E. (2009). Class, Ethnicity, Gender and Latino Entrepreneurship. New York: Routledge - Taylor \& Francis Group.

Waldinger, R. (1986). Through the Eye of the Needle: Immigrants and Enterprise in New York's Garment Trade. NYU Press.

Wang, Q., \& Wei, L. (2007). Entrepreneurship, ethnicity and local contexts: Hispanic entrepreneurs in three U.S. southern metropolitan areas. GeoJournal, Vol. 68(Issue 2), PP.167-182.

Wilson, K., \& Portes, A. (1980). Immigrant Enclaves: A Comparison of the Cuban and Black Economies in Miami. America Journal of Sociology(86), 295-319.

Yang, S. (2005). English Non-Fluency and Income Penalty for Hispanic Workers. Retrieved from http://citation.allacademic.com//meta/p_mla_apa_research_citation/0/3/4/8/3/pag es34834/p34834-1.php

Yarzebinski, J. (1992). Understanding and Encouraging the Entrepreneur. Economic Development Review. Retrieved from http://ebookbrowse.com/gdoc.php?id=273047875\&url=f71417e4940f9bf00ca1e6 3dc56122d4

Zacharis, A. L., William D. Bygrave, and Dean A. Sheperd. (2010). Global Entrepreneurship Monitor: National Entrepreneurship Assessment, United States. Kauffman Center for Entrepreneurial Leadership at the Ewing Marion Kauffman Foundation, 3.

Zarrugh, L. (2007). From Workers to Owners: Latino Entrepreneurs in Harrisonburg, Virginia. Human Organization.

Zimmerer, T., Scarborough, N., \& Wilson, D. (2010). Essentials of Entrepreneurship and Small Business Management (7th ed.). 


\section{APPENDICES}

\section{APPENDIX 1}

Hispanic or Latino Population for the United States, Regions, and States, and for Puerto Rico: 2000 and 2010

\begin{tabular}{|c|c|c|c|c|c|c|c|c|c|c|}
\hline \multirow[b]{3}{*}{ Area } & \multicolumn{3}{|c|}{2000} & \multicolumn{3}{|c|}{2010} & \multicolumn{4}{|c|}{ Population change, 2000 to 2010} \\
\hline & \multirow[b]{2}{*}{ Total } & \multicolumn{2}{|c|}{ Hispanic or Latino } & \multirow[b]{2}{*}{ Total } & \multicolumn{2}{|c|}{ Hispanic or Latino } & \multicolumn{2}{|c|}{ Total } & \multicolumn{2}{|c|}{ Hispanic or Latino } \\
\hline & & Number & $\begin{array}{r}\begin{array}{r}\text { Percent } \\
\text { of total } \\
\text { population }\end{array} \\
\end{array}$ & & Number & $\begin{array}{r}\text { Percent } \\
\text { of total } \\
\text { population }\end{array}$ & Number & $\begin{array}{l}\text { Per- } \\
\text { cent }\end{array}$ & Number & $\begin{array}{l}\text { Per- } \\
\text { cent }\end{array}$ \\
\hline United States... & $281,421,906$ & $35,305,818$ & 12.5 & $308,745,538$ & $50,477,594$ & 16.3 & $27,323,632$ & 9.7 & $\mid 15,171,776$ & 43.0 \\
\hline REGION & & & & & & & & & & \\
\hline & $53,594,378$ & $5,254,087$ & 9.8 & $55,317,240$ & $6,991,969$ & 12.6 & $1,722,862$ & 3.2 & $1,737,882$ & 33.1 \\
\hline Midwest . & $64,392,776$ & $3,124,532$ & 4.9 & $66,927,001$ & $4,661,678$ & 7.0 & $2,534,225$ & 3.9 & $1,537,146$ & 49.2 \\
\hline South... & $100,236,820$ & $11,586,696$ & 11.6 & $114,555,744$ & $18,227,508$ & 15.9 & $14,318,924$ & 14.3 & $6,640,812$ & 57.3 \\
\hline West $\ldots \ldots \ldots \ldots \ldots$ & $63,197,932$ & $15,340,503$ & 24.3 & $71,945,553$ & $20,596,439$ & 28.6 & $8,747,621$ & 13.8 & $5,255,936$ & 34.3 \\
\hline STATE & & & & & & & & & & \\
\hline & $4,447,100$ & 75,830 & 1.7 & $4,779,736$ & 185,602 & 3.9 & 332,636 & 7.5 & 109,772 & 144.8 \\
\hline Alaska.. & 626,932 & 25,852 & 4.1 & 710,231 & 39,249 & 5.5 & 83,299 & 13.3 & 13,397 & 51.8 \\
\hline izona & $5,130,632$ & $1,295,617$ & 25.3 & $6,392,017$ & $1,895,149$ & 29.6 & $1,261,385$ & 24.6 & 599,532 & 46.3 \\
\hline & $2,673,400$ & 86,866 & 3.2 & $2,915,918$ & 186,050 & 6.4 & 242,518 & 9.1 & 99,184 & 114.2 \\
\hline alifornia . & $33,871,648$ & $10,966,556$ & 32.4 & $37,253,956$ & $14,013,719$ & 37.6 & $3,382,308$ & 10.0 & $3,047,163$ & 27.8 \\
\hline Colorado. & $4,301,261$ & 735,601 & 17.1 & $5,029,196$ & $1,038,687$ & 20.7 & 727,935 & 16.9 & 303,086 & 41.2 \\
\hline nnecticut. & $3,405,565$ & 320,323 & 9.4 & $3,574,097$ & 479,087 & 13.4 & 168,532 & 4.9 & 158,764 & 49.6 \\
\hline laware & 783,600 & 37,277 & 4.8 & 897,934 & 73,221 & 8.2 & 114,334 & 14.6 & 35,944 & 96.4 \\
\hline Columbia. & 572,059 & 44,953 & 7.9 & & 54,749 & 9.1 & & 5.2 & 9,796 & 21.8 \\
\hline Florida & $15,982,378$ & $2,682,715$ & 16.8 & $18,801,310$ & $4,223,806$ & 22.5 & $2,818,932$ & 17.6 & $1,541,091$ & 57.4 \\
\hline Georgia & $8,186,453$ & 435,227 & 5.3 & $9,687,653$ & 853,689 & 8.8 & $1,501,200$ & 18.3 & 418,462 & 96.1 \\
\hline & & & 7.2 & & & 8.9 & & 12.3 & & 37.8 \\
\hline & & & 7.9 & & & 11.2 & & 21.1 & & 73.0 \\
\hline & $12,419,293$ & $1,530,262$ & 12.3 & $12,830,632$ & $2,027,578$ & 15.8 & 411,3 & 3.3 & 497,316 & 32.5 \\
\hline & & 214,536 & 3.5 & & 389,707 & 6.0 & 17 & 6.6 & & 81.7 \\
\hline$\ldots \ldots \ldots \ldots$ & 926,324 & 82,473 & 2.8 & 046,355 & 151,544 & 5.0 & 120,0 & 4.1 & 69,071 & 83.7 \\
\hline & 418 & 188,252 & 7.0 & & 300,042 & 10.5 & 164,7 & 6.1 & 111,790 & 59.4 \\
\hline & $4,041,769$ & 59,939 & 1.5 & $4,339,367$ & 132,836 & 3.1 & 297,598 & 7.4 & 72,897 & 121.6 \\
\hline & & 107,738 & 2.4 & & 60 & 4.2 & & 1.4 & 84,822 & 78.7 \\
\hline Maine & $1,274,923$ & 9,360 & 0.7 & $1,328,361$ & 16,935 & 1.3 & 53,438 & 4.2 & 7,575 & 80.9 \\
\hline Maryland & $5,296,486$ & 227,916 & 4.3 & $5,773,552$ & 470,632 & 8.2 & 477,066 & 9.0 & 242,716 & 106.5 \\
\hline & & & 6 & & & 9.6 & & 3.1 & & 46.4 \\
\hline & & & 3. & & & 4. & & -0.6 & & 34.7 \\
\hline & & & 2. & & & 4. & & 7.8 & & 74.5 \\
\hline & & & 1.4 & & & 2. & & 4.3 & & 105.9 \\
\hline & $5,595,21$ & & 2. & 7 & 212,4 & 3.5 & & 7.0 & 93,878 & 79.2 \\
\hline & & & 2. & & & 2.9 & & 9.7 & & 58.0 \\
\hline & $1,711,26$ & 25 & 5. & 1 & 167,405 & 9.2 & 115,0 & 6.7 & & 77.3 \\
\hline & & & 19. & & & 26.5 & & 35.1 & & 81.9 \\
\hline New $\mathrm{Hz}$ & & & 1.7 & $1,316,470$ & 36,704 & 2.8 & 80,684 & 6.5 & 16,215 & 79.1 \\
\hline & & & & & & & & 4.5 & & 39.2 \\
\hline & & & & & & & & 13.2 & & 24.6 \\
\hline & 18,9 & & 15. & & & 17.6 & & 2.1 & & 19.2 \\
\hline & & & 4. & & & 8.4 & $1,4 \varepsilon$ & 18.5 & & 111.1 \\
\hline & & & 1.2 & & & 2.0 & & 4.7 & & 73.0 \\
\hline & $11,353,140$ & & 1.9 & 11,5 & & 3.1 & & 1.6 & & 63.4 \\
\hline & & & 5. & & & 8.9 & & 8.7 & & 85.2 \\
\hline & & & 8.0 & 3 & & 11.7 & 409,6 & 12.0 & & 63.5 \\
\hline & 12,2 & & 3. & & & 5. & & 3.4 & & 82.6 \\
\hline & 48,319 & & 8.7 & 2,567 & & 12.4 & 4,248 & 0.4 & 835 & 43 \\
\hline Sou & ,012,012 & & 2.4 & 4,6 & & 5.1 & 3,352 & 15.3 & 140,606 & 147.9 \\
\hline & & & & & & & & 7.9 & & 102.9 \\
\hline . & 3 & & 2. & & 290 & 4.6 & 656,8 & 11.5 & & 134.2 \\
\hline & $20, \varepsilon$ & & 32. & & & 37.6 & & 20.6 & & 41.8 \\
\hline & & & 9. & & 358,3 & 13. & & 23.8 & & 77.8 \\
\hline & & & 0.9 & & & 1.5 & & 2.8 & 3,704 & 67.3 \\
\hline & $7,07 \varepsilon$ & & 4.7 & & 631,825 & 7.9 & & 13.0 & 302,285 & 91.7 \\
\hline & 84,12 & & 7. & 0 & 755,790 & 11.2 & 830,4 & 14.1 & 314,281 & 71.2 \\
\hline West Virginia .... & $1,808,344$ & & 0.7 & $1,852,994$ & 22,268 & 1.2 & & 2.5 & & 81.4 \\
\hline Wisconsin ...... & $5,363,675$ & & 3.6 & & 336,056 & 5.9 & & 6.0 & 143,135 & 74.2 \\
\hline Wyomi & 493,782 & 31,669 & 6.4 & 563,626 & 50,231 & 8.9 & 69,844 & 14.1 & 18,562 & 58.6 \\
\hline Puerto Rico $\ldots \ldots$. & $3,808,610$ & $3,762,746$ & 98.8 & $3,725,789$ & $3,688,455$ & 99.0 & $-82,821$ & -2.2 & $-74,291$ & -2.0 \\
\hline
\end{tabular}


APPENDIX 2

Cover Letter - English

West VirginiaUniversity

Davis College of Agriculture, Natural Resources and Design

Dear Participant,

This letter is a request for you to take part in a research project to assess Latino Entrepreneurship in the State of West Virginia. This project is being conducted by Juan Arcila, MBA in the Division of Design and Merchandising at WVU with supervision of the director of the department Dr. Barbara McFall, for a Doctorate Degree in Human and Community Development. Your participation in this project is greatly appreciated and will take approximately 30-40 minutes to complete the interview. You will also have the opportunity to choose in what language you wish to be interviewed, Spanish or English.

Your involvement in this project will be kept as confidential as legally possible. All data will be reported in the aggregate. You must be 18 years of age or older to participate. I will not ask any information that should lead back to your identity as a participant. Your participation is completely voluntary. You may skip any question that you do not wish to answer and you may discontinue at any time. Your business will also not be disclosed at any given time. West Virginia University's Institutional Review Board acknowledgement of this project is on file.

I hope that you will participate in this research project, as it could be beneficial in understanding the reason for the lack of Latino Entrepreneurs in the state. Thank you very much for your time. Should you have any questions about this letter or the research project, please feel free to contact Juan Arcila at (304) 685-0432 or by e-mail at juan.arcila@email.wvu.edu.

Thank you for your time and help with this project.

Sincerely,

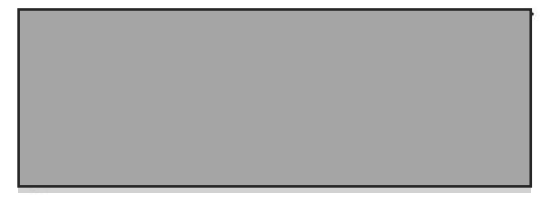

Juan Arcila 
APPENDIX 3

Cover Letter - Spanish

\section{WestVirginiaUniversity}

\section{Davis College of Agriculture, Natural Resources and Design}

Querido Participante,

Esta carta es una solicitud para que usted pueda participar en un proyecto de investigación para evaluar la iniciativa empresarial latina en el Estado de West Virginia. Este proyecto está siendo llevado a cabo por Juan Arcila, MBA en la división de Diseño y Mercancía de WVU con la supervisión de la directora del departamento, la Dra. Barbara McFall, para un Doctorado en Desarrollo Humano y de la Comunidad. Su participación en este proyecto es muy apreciada y este durara aproximadamente 30-40 minutos para completar la entrevista. Usted también tendrá la oportunidad de elegir en qué idioma desea ser entrevistado, Español o Inglés.

Su participación en este proyecto se mantendrá tan confidencial como sea legalmente posible. Todos los datos serán reportados en el agregado. Usted debe tener 18 años de edad o más para participar. No voy a pedir ninguna información que pueda conectar el proyecto con su identidad como participante. Su participación es completamente voluntaria. Usted puede negarse a responder cualquier pregunta y puede interrumpir en cualquier momento. Su negocio tampoco será revelado en ningún momento. El reconocimiento de la junta de Revisión Institucional de la Universidad de West Virginia ha sido archivado.

Espero que participe en este proyecto de investigación, ya que podría ser beneficioso para poder comprender la falta de empresarios latinos en el Estado. Muchas gracias por su tiempo. Si usted tiene alguna pregunta sobre esta carta 0 el proyecto de investigación, no dude en ponerse en contacto con Juan Arcila al (304) 685-0432 o por e-mail a juan.arcila@email.wvu.edu.

Gracias por su tiempo y por su ayuda en este proyecto,

Sinceramente,

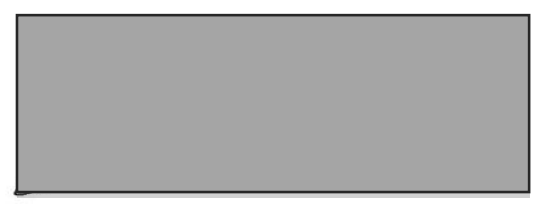

Juan Arcila 


\section{APPENDIX 4}

\section{Accuracy of English-SpanishTranslation Certificate}

WestVirginiaUniversity.

EBERLY COLLEGE OF ARTS AND SCIENCES

May 14, 2012

To Whom It May Concern:

After reviewing copies of the letter and interview in English and in Spanish, I affirm that the Spanish documents are an accurate translation of the

English documents.

Sincerely,

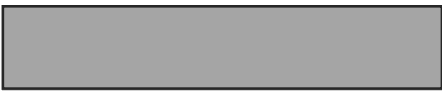

Sandra Dixon, Ph.D.

Assistant Professor of Spanish 


\section{APPENDIX 5}

English Questionnaire

Demographic Questionnaire*

Name:

Current Address:

Phone:

Email:

Birth Date:

Birth Place

\section{Residence Pattern:}

Born in until big, medium, little, village, rural

Moved to until big, medium, little, village, rural

Moved to until big, medium, little, village, rural

Moved to until big, medium, little, village, rural

\section{Sisters:}

First Name: present age now lives in

First Name: present age now lives in

First Name: present age now lives in 


\section{Brothers:}

First Name: present age now lives in

First Name: present age now lives in

First Name: present age now lives in

\section{Parents:}

Mother's name: present age now lives in

Father's name: present age now lives in

Marital Status:

Mother's place of birth:

Father's place of birth:

Occupation of mother:

Occupation of father:

Occupation and Education:

Occupation:

Company:

Education:

\section{Marital Status and History:}

Marital Status:

Children:

Name:

Age:

Gender:

Name:

Age:

Gender: 
Name:

Age: Gender:

Occupation of Spouse:

\section{Religion:}

Denomination:

\section{Semi-Structured Business Owner Interview*}

Interviewer: Introduce yourself and explain objective of the research and importance/contribution of participation. Begin with consent form and request permission to tape-record.

\section{Type of Business Owned/ Operations}

1. What type of business do you own?

2. When did you open your business?

3. What are your annual gross sales? (Interviewer: If respondent does not want to provide exact figure, offer following ranges: (a) less than 10,000, (b) 10,000-50,000, (c) 50,000-75,000, (d) 75,000-100,000or (e) 100,000 and over).

4. How did you select the type/line of business?

5. Did you have any prior business experience?

6. What was your occupation prior to current business? (Interviewer: assess whether prior experience was informal business ownership, or work in a similar business and if so was this business owned by a Latino)

7. How did you start your business? (Self-started, bought existing business, inherited, etc.)

8. Do you do any marketing/advertising? (Interviewer: ask where and how they advertise)

9. What do you do in order to find new customers?

10 . Who are the majority of your clients/customers (are they mostly Latino?)

11. How many employees do you have?

12. Who are your employees? (Interviewer: ask if they are family members. If not family members ask if Latino) 


\section{Economic Nature/ Government Support}

13. Do you have a second source of income? (Interviewer: ask about second job or spouse employment or any other income).

14. If you were to start a business today, what would you do differently?

15. What advice would you give someone who was about to open a business?

16. How did you obtain funding for this business venture?

17. What governmental offices for entities did you go to in order to reach out for funding 18. Are you aware of the several organizations that provide funding for minorities in West Virginia, If so which ones?

19. If you knew more information about these funding sources, would that have helped your business getting started?

20. Was funding ever an issue for your business venture? Is so, how did you surpass it? If not, why not?

21. How did you obtain start-up capital? (Personal funds/family loans/financial institutions)

22. If you were going to open a business today, where would you go for financing?

23. What were some of the problems/difficulties you encountered before you opened your business?

24. What are some of the problems/difficulties you encounter now, as you are running it?

25. What is your vision for your business? Do you have a succession plan?

26. Are you planning on opening another business or expanding your current one?

27. Do you feel that funding (if necessary) was easy to obtain?

28. Are you familiar with any of these programs?
a. INNOVA
b. TechConnectWV
c. Biomass Crop Assistance Program
d. Neighborhood Investment Program (NIP)
e. Tax Increment Financing (TIF)
f. Microloan Program
g. WV Linked Deposit Fund
h. Military Incentive Program (MIP)
i. On the Job Training (OJT)
j. Matching Advertising Partnership Program (MAPP)
k. Recreational Trails Program
I. Scenic Byways Program
m. WVEDA Direct Loan Program
n. Loan Insurance Program
o. Small Business Administration (SBA) 
p. Small Business Development Center (SBDC)

29. Do you think that these programs are being promoted and advertised enough in the state of West Virginia?

30. If you had any prior knowledge about any of these programs before opening your business, would that have helped your business?

Thank you for your time and help with this project.

Would you be willing to refer us to another Latino small business owner who you think would be willing to participate in our study?

*Parts of this questionnaire are informed by McCracken, 1988, p. 67. And Shinnar, Young, 2008. 
APPENDIX 6

Cuestionario En Español

Cuestionario Demográfico*

Nombre:

Dirección Actual:

Número Telefónico:

Correo Electrónico:

Fecha de Nacimiento:

Lugar de Nacimiento:

\section{Patrones de Residencia:}

Nacido en vivió hasta Grande, Mediana, Pequeña, Pueblo, Rural

Mudado a vivió hasta Grande, Mediana, Pequeña, Pueblo, Rural

Mudado a vivió hasta Grande, Mediana, Pequeña, Pueblo, Rural

Mudado a vivió hasta Grande, Mediana, Pequeña, Pueblo, Rural

Numero de Hermanas:

Nombre: Edad Vive en

Nombre: Edad Vive en

Nombre: Edad Vive en 


\section{Numero de Hermanos:}

Nombre: Edad Vive en

Nombre: Edad Vive en

Nombre: Edad Vive en

\section{Padres:}

Nombre de la Madre: Edad Vive en

Nombre del Padre: Edad Vive en

Estado Civil de los padres:

Lugar de nacimiento de la Madre:

Lugar de nacimiento del Padre:

Profesión de la Madre:

Profesión del Padre:

\section{Profesión y Educación:}

Profesión:

Nombre del Negocio:

Educación:

\section{Estado Civil e Historia:}

Estado Civil:

Hijos:

Nombre:

Edad:

Sexo:

Nombre:

Edad:

Sexo: 
Nombre:

Edad: Sexo:

Ocupación de Esposa/o:

\section{Religión:}

Denominación:

\section{Entrevista estructurada para dueño de negocio*}

Entrevistador: Presentarse y explicar el objetivo de la investigación y la importancia/contribución de la participación. Empezar con la autorización y pedir permiso para poder grabar la entrevista.

\section{Tipo de Negocio/ Operaciones}

1. ¿Qué tipo de negocio tiene?

2. ¿Cuando abrió su negocio?

3. ¿Cuál es el ingreso anual del negocio? (Entrevistador: si el entrevistado no desea proveer una cifra exacta, ofrecer los siguientes rangos: (a) menos de $\$ 10,000$, (b) $10,000-\$ 50,000$, (c) $\$ 50,000-\$ 75,000$, (d) $\$ 75,000-\$ 100,000$ o (e) más de $\$ 100,000)$.

4. ¿Cómo selecciono el tipo de negocio que iba a abrir?

5. ¿Tenía usted alguna clase de experiencia previa en negocios?

6. ¿Cuál era su ocupación antes de abrir su negocio? (Entrevistador: establecer si la experiencia previa fue emprendimiento informal, o trabajo en un negocio similar and si fue así si ese negocio era manejado por algún latino)

7. ¿Cómo empezó su negocio? (empezó solo, compro un negocio existente, lo heredo, etc.)

8. ¿Hace usted alguna clase de mercadeo o propaganda? (entrevistador: preguntar dónde y cómo)

9. ¿Qué hace usted para encontrar clientes nuevos?

10. ¿Quiénes son la mayoría de sus clientes? (¿son la mayoría Latinos?)

11. ¿Cuántos empleados tiene?

12. ¿Quiénes son sus empleados? (entrevistador: preguntar si son miembros de su familia, si no preguntar si son Latinos)

13. ¿Tiene usted una segunda fuente de ingresos? (entrevistador: preguntar si tiene un segundo trabajo, la esposa/o trabaja, o cualquier otra forma de ingreso)

14. ¿Si usted fuese a empezar un negocio hoy, que haría diferente?

15. ¿Qué consejo le daría a alguien que está a punto de abrir un negocio? 


\section{Naturaleza Económica /Apoyo Gubernamental}

16. ¿Cómo obtuvo financiamiento para abrir este negocio?

17. ¿Qué oficinas gubernamentales o entidades utilizo para obtener financiamiento?

18. ¿Está usted consciente de la cantidad de organizaciones que proveen financiamiento para minorías en West Virginia?

19. ¿Si usted supiera más información acerca de estas fuentes de financiamiento, habría esto ayudado a comenzar su negocio?

20. ¿Fue financiamiento un problema para su negocio? ¿Si lo fue como lo supero? Si no, ¿por qué no?

21. ¿Cómo obtuvo el capital para empezar su negocio? (fondos personales/prestamos familiares/instituciones financieras)

22. ¿Si usted fuera a abrir un negocio hoy en día, a donde iría para financiamiento?

23. ¿Cuáles fueron algunos de los problemas/dificultades que encontró antes de abrir su negocio?

24. ¿Cuales son algunos problemas/dificultades que encuentra ahora que ya abrió su negocio?

25. ¿Cuál es su visión para su negocio? ¿Tiene un plan de sucesión?

26. ¿Planea abrir un segundo negocio o expandir su negocio algún día?

27. ¿Siente usted que fue fácil obtener fondos (si necesario) para abrir su negocio?

28. ¿Es usted familiar con alguno de los siguientes programas?
a. INNOVA
b. TechConnectWV
c. Biomass Crop Assistance Program
d. Neighborhood Investment Program (NIP)
e. Tax Increment Financing (TIF)
f. Microloan Program
g. WV Linked Deposit Fund
h. Military Incentive Program (MIP)
i. On the Job Training (OJT)
j. Matching Advertising Partnership Program (MAPP)
k. Recreational Trails Program
I. Scenic Byways Program
m. WVEDA Direct Loan Program
n. Loan Insurance Program
o. Small Business Administration (SBA)
p. Small Business Development Center (SBDC)

29. ¿Cree usted que estos programas son lo suficientemente promocionados en el 
estado de West Virginia?

30. ¿Si usted hubiera sabido de algunos de estos programas antes de abrir su negocio, habría esto ayudado a su negocio?

Muchas gracias por su tiempo y ayuda con este proyecto.

¿Estaría usted dispuesto a referirnos a otros Latinos que sean dueños de negocios que podrían ser participes de este estudio?

${ }^{*}$ Parte de este cuestionario fue informado por McCracken, 1988, p. 67. And Shinnar, Young, 2008 y traducido por el autor. 


\section{APPENDIX 7}

Interviews Transcriptions

\section{$\underline{\text { Participant \#1 - Interview }}$}

PARTICIPANT \#1: Hello

INTERVIEWER: how are you doing? This is Juan Arcila

PARTICIPANT \#1: Yes I got the email

INTERVIEWER: I contacted you earlier and my boss has also contacted you stating that this is real research

PARTICIPANT \#1: ok yes it is

INTERVIEWER: do you have a minute to be interviewed now or would you like to set up a new time for the interview

PARTICIPANT \#1: now would be fine

INTERVIEWER: Ok, first of all, I would like to let you know that this conversation will be recorded but in no way will your name, the name1 of your business, or any kind of figures will be published, it will all be anonymous, I will assign numbers to the conversation so it will all be anonymous, ok?

PARTICIPANT \#1: Ok

INTERVIEWER: would you like me to do the interview in English or Spanish?

PARTICIPANT \#1: English is fine

INTERVIEWER: Could you please state your full name and last name?

PARTICIPANT \#1:

INTERVIEWER: Ok, what's your phone number?

PARTICIPANT \#1:

INTERVIEWER: What is your Email address?

PARTICIPANT \#1:

INTERVIEWER: What is your current address?

PARTICIPANT \#1:

INTERVIEWER: Ok great, one more thing if at any point you feel uncomfortable by any of the questions you can simply go ahead and say you do not want to answer it and I will skip that question and move on to the next one. Ok? 
PARTICIPANT \#1: ok

INTERVIEWER: What is your birth date?

PARTICIPANT \#1: April $5^{\text {th }}, 1953$

INTERVIEWER: What is your birth place?

PARTICIPANT \#1: The Dominican Republic

INTERVIEWER: What city in the Dominican Republic?

PARTICIPANT \#1: San Francisco de Macoris

INTERVIEWER: And you moved from the Dominican Republic to the United States?

PARTICIPANT \#1: Yes

INTERVIEWER: When?

PARTICIPANT \#1: Oh my God, When I was 17 in 1970

INTERVIEWER: Ok, and you moved directly to West Virginia, or did you go to another state first?

PARTICIPANT \#1: Washington, D.C

INTERVIEWER: And what made you move to West Virginia?

PARTICIPANT \#1: School

INTERVIEWER: What did you do in school?

PARTICIPANT \#1: It was kind of like a spiritual school

INTERVIEWER: Ok, Great, how many sisters and brothers do you have?

PARTICIPANT \#1: WOW, this is getting very personal

INTERVIEWER: Like I said before, if you feel in any way uncomfortable about a question you can simply not answer it and I will move forward. This is just the demographic part of the interview where I get the feeling of how you were raised, and the environment you were born in

PARTICIPANT \#1: Ok, well I have two brothers

INTERVIEWER: Ok, what's your immigration status?

PARTICIPANT \#1: I am a US citizen

INTERVIEWER: Ok and where are your parents from? Are they from the Dominican Republic as well?

PARTICIPANT \#1: yes

INTERVIEWER: What is your current occupation? 
PARTICIPANT \#1: I am a chef, caterer

INTERVIEWER: Are you married?

PARTICIPANT \#1: Yes

INTERVIEWER: Do you have any children?

PARTICIPANT \#1: Yes

INTERVIEWER: How many?

PARTICIPANT \#1: two

INTERVIEWER: Alright, now I can move on to the business part of the interview, what type of business do you own?

PARTICIPANT \#1: Catering service

INTERVIEWER: When did you open your business?

PARTICIPANT \#1: 2005

INTERVIEWER: What are your annual gross sales?

PARTICIPANT \#1: Ok, I live that blank

INTERVIEWER: Ok, how did you select the type of business that you wanted to open?

PARTICIPANT \#1: Because that's what I do, I cook

INTERVIEWER: Did you have any prior business experience?

PARTICIPANT \#1: No

INTERVIEWER: What was your occupation prior to opening your business?

PARTICIPANT \#1: I was a chef at another restaurant

INTERVIEWER: How did you start your business, did you started by yourself? Did you buy somebody else's business?

PARTICIPANT \#1: By myself

INTERVIEWER: Do you do any marketing/advertising?

PARTICIPANT \#1: I have a website

INTERVIEWER: And that's where you do all your advertising?

PARTICIPANT \#1: Yes, the rest is word of mouth

INTERVIEWER: Ok, what do you do in order to find new customers? 
PARTICIPANT \#1: It is word of mouth, I'm good

INTERVIEWER: Ok, who are the majority of your clients/customers, are they mostly Latino?

PARTICIPANT \#1: I have no Latino customers

INTERVIEWER: What type of food do you cook?

PARTICIPANT \#1: Mediterranean food

INTERVIEWER: Do you have any employees?

PARTICIPANT \#1: Just part time

INTERVIEWER: Are they family members?

PARTICIPANT \#1: No, people I found

INTERVIEWER: Do you have a second source of income?

PARTICIPANT \#1: No

INTERVIEWER: If you were to start a business today, what would you do differently?

PARTICIPANT \#1: Nothing, I am doing just fine. Can't change anything, if I change anything I might fail

INTERVIEWER: What advice would you give someone who was about to open a business?

PARTICIPANT \#1: Work hard and be good

INTERVIEWER: How did you obtain funding for this business venture?

PARTICIPANT \#1: I had been saving

INTERVIEWER: So it was all personal savings? You did not get a loan?

PARTICIPANT \#1: I did not want to owe anything to anybody, little by little

INTERVIEWER: Very well done, so you didn't go to any governmental offices or entities in order to reach out for funding

PARTICIPANT \#1: No, no

INTERVIEWER: Do you think that maybe if you had more information about governmental entities that would have helped you opening your business or...

PARTICIPANT \#1: No, I was very sure of what I was doing; I never wanted to find any funding because I would have to spend my entire life paying for it

INTERVIEWER: What are some of the problems that you encounter now as a Participant in West Virginia? 
PARTICIPANT \#1: I really don't have any problems with my business, I choose my clients, I would not change anything and I did not get hit by the crisis so I'm not encountering any problems right now

INTERVIEWER: That's great, so what is your vision for this business? Do you have a succession plan? Are you planning on maybe getting your children involved?

PARTICIPANT \#1: No, I am waiting until I am 65 to retire

INTERVIEWER: So you are not planning on maybe opening another business or expanding your current one?

PARTICIPANT \#1: No, because if I get bigger I cannot control the quality of my food, and the only reason I am successful is because the quality of my food is very high. If I don't cook food doesn't go out of here

INTERVIEWER: For you as a Participant, what's the biggest advantage that you have over someone that has a regular job?

PARTICIPANT \#1: That I like what I do?

INTERVIEWER: have you encountered any obstacles as a Latina, and as a Latina Participant in West Virginia?

PARTICIPANT \#1: Not at all, never have and I never will

INTERVIEWER: How long have you had your business for?

PARTICIPANT \#1: Since 2005, so 7 years

INTERVIEWER: Ok is there anything else you might want to tell me? The interview is basically over, so I will ask you a couple of open ended questions, is there anything you could tell me that could maybe help Latino Participants in West Virginia, any advice?

PARTICIPANT \#1: I do, and that is that if you are going to open a business, make sure that you maintain a quality that is over the top, because that is what it boils down to. If you don't like what you do, and you open your business just because somebody said it would be a good business to open, it is not going to work. I work 7 days a week, 24 hours, because if people require a party on a Sunday then good-bye Sunday. So make sure whatever you do you do I right, and the services that you offer are top of the line.

INTERVIEWER: Pretty much passion would sum it up, just being passionate about what they do

PARTICIPANT \#1: unless they have that, it becomes a boring job. If you have control of your business that is the best thing, you have to rely on manager and sometimes they don't have the passion

INTERVIEWER: So would you advice to keep it small?

PARTICIPANT \#1: It depends on how many people you have to support, if you have a family of 10, it's not the same than supporting a family of 2 , keep it in control, because when it falls in the hands of people that don't care everything goes down, because you are relying on other people, I have been blessed, I have a great business, great support, and the ability to work by myself, I would not change a thing 
INTERVIEWER: And once these things go down, the business will go down with it, ok thank you so much for your time, if you would like me to, I could send you a copy of the project when I am done. Thank you again

PARTICIPANT \#1: Ok, I would like a copy of it please, you have a good day.

\section{$\underline{\text { Participant \#2 - Interview }}$}

\section{PARTICIPANT \#2:}

INTERVIEWER: Hello, may I speak with please?

PARTICIPANT \#2: This is her

INTERVIEWER: Hello this is Juan Arcila, the West Virginia University student

PARTICIPANT \#2: yes how are you?

INTERVIEWER: I am doing well; do you have some time to do the interview now?

PARTICIPANT \#2: Yes

INTERVIEWER: Ok, let me just tell you again it's going to be a fairly quick interview you can choose what question to answer and what question not to answer if you are uncomfortable in any way by any of the questions, I will skip to the next questions. Also, would you like me to do the interview in English or Spanish?

PARTICIPANT \#2: In English or Spanish, better in English, I don't want to speak Spanglish

INTERVIEWER: Also, I need to let you know this phone call is being recorded and in no way or shape is your name, the name of your company or any information going to be included in the paper itself, this is going to be completely anonymous and will be used in a more general manner, okay?

PARTICIPANT \#2: Ok, sounds good.

INTERVIEWER: Ok so, first of all we'll start with some demographic questions, what's your full name and last name?

PARTICIPANT \#2: It is , and people call me

INTERVIEWER: What the name of your company?

PARTICIPANT \#2:

INTERVIEWER: What is your current address?

PARTICIPANT \#2: 
INTERVIEWER: Ok great, one more thing if at any point you feel uncomfortable by any of the questions you can simply go ahead and say you do not want to answer it and I will skip that question and move on to the next one. Ok?

PARTICIPANT \#2: Ok

INTERVIEWER: Ok, what's your phone number?

PARTICIPANT \#2:

INTERVIEWER: What is your Email address?

PARTICIPANT \#2:

INTERVIEWER: What is your birth date?

PARTICIPANT \#2: March $15^{\text {th }}, 1979$

INTERVIEWER: What is your birth place?

PARTICIPANT \#2: I was born in Morelia, Mexico, but I grew up in a little town called Gancho de Las Cañas, in the middle of nowhere

INTERVIEWER: And when did you move to the United States?

PARTICIPANT \#2: I moved to the United States when I was 18, well 17/18, and I came here because when I graduated high school I got recruited by the Mexican Basketball National team to play in Mexico City but two days before I had to go I broke my collar bone, and I couldn't go and my parents took a bus four months later and we travelled the U.S and we stopped in West Virginia and I went to play with my brothers and the coach for the university of Charleston saw me play and offer me a scholarship.

INTERVIEWER: Well, that's an amazing story, congratulations

PARTICIPANT \#2: Thank you, that's how I got here...

INTERVIEWER: So are you married?

PARTICIPANT \#2: I'm single.

INTERVIEWER: What did you do in school, at the University of Charleston?

PARTICIPANT \#2: I had graduated in Mexico in architecture, but the University of Charleston did not have an architecture program, so I went into the Interior design program and graduated with a bachelor's degree.

INTERVIEWER: When did you start your company?

PARTICIPANT \#2: I started my company in 2004

INTERVIEWER: Had you already graduated? 
PARTICIPANT \#2: Yes, I was working in my field, and I started making [condiments], and all my friends used to tell me I should sell them, and I would tell them they were nuts because it caused so much money to make one batch, and friends always insisted I should start a business selling [condiments], because every time I made it they would love it. In fact they signed me up for this contest, without me knowing, and I actually won, so when I got the $\$ 800$ loan from a friend, I decided to start my business and see what happened I won that competition by unanimous vote, and I thought maybe I did have something there, so that's how I started the company. But it was tough for me because when I went to school I only took on business class, Business 101 and that's it, so I didn't know how to start or run a business so, it was quite difficult. And my main research source became Google.

INTERVIEWER: So what was your main source of funding?

PARTICIPANT \#2: Well a friend who believed in my gave me an initial loan/investment of $\$ 800$ and with that I bought materials and started making my own [condiments]

INTERVIEWER: That is incredible, so what is your current occupation?

PARTICIPANT \#2: I make [condiments] for a living.

INTERVIEWER: Do you have any children?

PARTICIPANT \#2: No

INTERVIEWER: Alright, now I can move on to the business part of the interview, what type of business do you own?

PARTICIPANT \#2: [condiments] manufacturing company

INTERVIEWER: What are your annual gross sales?

PARTICIPANT \#2: $1.5 \$$ million annual gross sales

INTERVIEWER: How did you start your business, did you started by yourself? Did you seek out for any more help other than Google?

PARTICIPANT \#2: It was really challenging for me because there was nobody that I could turn to for advice, because when I tried to talk to other [condiments] companies they would think I was competition and just didn't even talk to me, but basically it was just Google, and I didn't have any way of talking to anybody, I went to the SBA and other governmental agencies and got nothing but brochures of "how to's" but no actual help. I was not looking to collect brochures and information on how to start a business, I was looking for an individual that could actually guide me through the process or at least explain the steps necessary to start a business. There were many challenges there I had studied interior design in college and had no idea how to start a business, when my friends told me to start selling my product; I decided to start my business with an initial $\$ 800$ investment from a friend. But it was not easy; I did not know how to start a business and had no idea I was going to have to do so many things regarding labels, FDA approval, trademark and copyrights

INTERVIEWER: So you felt like there was very little support for you 
PARTICIPANT \#2: yeah I was just being provided with information I could have found online on my own, and it just felt like they could not really help me, I mean I didn't even have a business plan when I started my business.

INTERVIEWER: What other challenges did you experience when starting your business?

PARTICIPANT \#2: the FDA approval was probably one of the most difficult things in the process, I had to find a kitchen that was FDA approved in other to make my products, and before I did so they would call me up and tell me to just give up and not even try to go through with my business, they now call me and say: I guess we were wrong about not starting that business huh? Also the first big order that we received was a bit of an issue, because we had to find an FDA approved kitchen, which was very far away. I only had enough money to pay one employee, therefore me and her, had to drive a long way and work throughout the night in order to fulfill this big order for this big supermarket chain. It was very challenging but we made it; if we hadn't maybe my business would have never survived

INTERVIEWER: did you do any marketing or advertisement when you started?

PARTICIPANT \#2: nope, I've never spent a penny on marketing, I do everything by word of mouth and it just grew like that

INTERVIEWER: who is your client base? Are they Latino?

PARTICIPANT \#2: they are all Americans, I do not think I sell or have sold one single product to Latinos directly; I mostly deal with stores like Whole Foods, and now Wal-Mart

INTERVIEWER: You mentioned before that you went to the SBA, did you go to any other entities?

PARTICIPANT \#2: No, I just pretty much did it on my own.

INTERVIEWER: Do you have any employees?

PARTICIPANT \#2: I have 7 employees

INTERVIEWER: Are they family members or friends?

PARTICIPANT \#2: No, they are people that help me in the manufacturing of my product and have some of them been with me since day one

INTERVIEWER: What is some advice you would give a Latino trying to start a business in West Virginia?

PARTICIPANT \#2: be perseverant and try your hardest at all times, you can create your own destiny with hard work.

INTERVIEWER: Alright, well thank you so much for your help. I really appreciate it.

PARTICIPANT \#2: no problem 


\section{$\underline{\text { Participant \#3 - Interview }}$}

PARTICIPANT \#3:

INTERVIEWER: Buenos días, puedo hablar con la señora

por favor?

PARTICIPANT \#3: Ella habla

INTERVIEWER: Hola señora como esta? Habla con Juan Arcila, de West Virginia University

PARTICIPANT \#3: ahh si, hola como esta?

INTERVIEWER: muy bien gracias, tiene un poco de tiempo para hacer la entrevista en este momento?

PARTICIPANT \#3: Si

INTERVIEWER: Ok, déjeme solo decirle que en la entrevista usted puede escoger responder la pregunta que quiera, y la que no quiera responder no es para nada obligatoria, usted prefiere hacer la entrevista en español o inglés?

PARTICIPANT \#3: Prefiero hacerla en español

INTERVIEWER: perfecto, también necesito que sepa que esta entrevista está siendo grabada para luego hacer parte de un estudio académico, pero que en ningún momento su identidad será divulgada ni conocida por nadie que lea el estudio, ok?

PARTICIPANT \#3: ok, muchas gracias

INTERVIEWER: Bueno, entonces empecemos con unas preguntas demográficas, usted como se llama?

PARTICIPANT \#3: Me llamo

INTERVIEWER: Como se llama su negocio?

PARTICIPANT \#3:

INTERVIEWER: Cuál es su dirección actual?

PARTICIPANT \#3:

INTERVIEWER: Cuál es su número telefónico?

PARTICIPANT \#3: Celular o de mi negocio?

INTERVIEWER: el del negocio está bien

PARTICIPANT \#3:

INTERVIEWER: Cuál es su dirección de correo electrónico?

PARTICIPANT \#3: No tengo correo electrónico, pero si quiere le doy el di mi hermana, es: 
INTERVIEWER: Cuál es su fecha de Nacimiento?

PARTICIPANT \#3: 1954

INTERVIEWER: En donde nació?

PARTICIPANT \#3: Yo nací en Guayaquil, Ecuador

INTERVIEWER: Cuando usted vino a los Estados Unidos, vino directamente a West Virginia, o fue a otro lugar primero?

PARTICIPANT \#3: Yo vine primero a vivir a Maryland y después me mude a West Virginia hace 5 anos.

INTERVIEWER: Cuantos hermanos/as tiene y donde viven?

PARTICIPANT \#3: Tengo 8 hermanos, 4 viven en Ecuador, y 4 Viven aquí, una en West Virginia conmigo, y los otros en Maryland.

INTERVIEWER: Sus padres donde nacieron?

PARTICIPANT \#3: Mis padres nacieron en Ecuador

INTERVIEWER: Y cuál era la profesión de sus padres?

PARTICIPANT \#3: Mi papa era un comerciante, tenía un negocio en Guayaquil, y desde que soy pequeña trabajaba con mi papa en su negocio.

INTERVIEWER: Usted ha ido a la universidad?

PARTICIPANT \#3: no, yo me gradué del colegio y me vine para acá a trabajar

INTERVIEWER: Que tipo de negocio tiene?

PARTICIPANT \#3: Tengo una tienda que vende productos Latinos.

INTERVIEWER: Cuando abrió su negocio?

PARTICIPANT \#3: Yo abrí mi negocio en el 2005

INTERVIEWER: Cual es el ingreso anual de su negocio?

PARTICIPANT \#3: Prefiero no responder esa pregunta

INTERVIEWER: Tiene usted alguna clase de experiencia con tener negocios y manejarlos?

PARTICIPANT \#3: Si, Nosotros siempre hemos tenido negocios en mi familia. Cuando vivíamos en Ecuador mi abuelo tenía una tienda, y mi papa la empezó a manejar cuando yo era muy joven. Entonces para mi es normal tener un negocio, además que he tenido la posibilidad de aprender de mi papa a manejar los clientes y los distribuidores, lo cual me ha ayudado muchísimo a montar mi negocio actual

INTERVIEWER: Cuando usted empezó su negocio lo hizo con un socio o lo hizo sola? 
PARTICIPANT \#3: Sola, el negocio es solamente mío

INTERVIEWER: Usted hace algún tipo de mercadeo o publicidad?

PARTICIPANT \#3: no, no tengo plata para desperdiciar en esas cosas, antes sacaba avisos en el periódico, pero con la situación como esta, no se puede

INTERVIEWER: Quienes son la mayoría de sus clientes?

PARTICIPANT \#3: son casi 100\% Latinos que viven aquí o pasan por el pueblo

INTERVIEWER: Tiene usted empleados? Son gente que hace parte de su familia?

PARTICIPANT \#3: Si, acá trabajan solamente familiares, tampoco hay plata para contratar a nadie más.

INTERVIEWER: Qué consejo le daría a alguien que está a punto de abrir un negocio en West Virginia.

PARTICIPANT \#3: Le diría que no lo abra, y que tenga mucho cuidado con los gastos iniciales. Mire yo pensé que esto iba a ser muchísimo más fácil y mejor para mí y mi familia. Lamentablemente estaba equivocada, este negocio ha arruinado mi familia, mi esposo ya no está con nosotros gracias al negocio, mi hermana y yo estamos en un montón de problemas, y la gente ya no compra nada, la economía no ayuda y este negocio está perdiendo plata diariamente. Yo estoy segura que si esta situación no cambia, dentro de seis meses cierro el negocio y me dedico a hacer otra cosa. Yo no sé qué voy a hacer, pero si la situación continúa como esta me va a tocar cerrar el negocio en seis meses. Ya es muchísimo tiempo que estoy perdiendo dinero, y no puedo seguir así, así es que si para Junio no cambia la situación, cierro el negocio y me dedico a hacer otra cosa

INTERVIEWER: Lo siento mucho, como hizo usted para conseguir financiamiento para empezar su negocio?

PARTICIPANT \#3: Utilicé mis ahorros, cuando yo llegue acá me compre una casa en Maryland por $\$ 130,000$ y después la vendí por $\$ 300,000$ entonces con esos casi $\$ 200,000$ de utilidad abrí el negocio en West Virginia

INTERVIEWER: Y no le pidió ayuda a ninguna organización gubernamental financiera o de otra naturaleza?

PARTICIPANT \#3: No, Yo no busque ayuda con ninguna agencia del gobierno porque ni siquiera confió en los policías del pueblo. Estos policías me están arruinando el negocio, porque saben que la mayoría de mis clientes son Latinos entonces se paran afuera del mercado y esperan a que salgan mis clientes y les empiezan a pedir papeles y a molestarlos. Lamentablemente muchos de mi clientes no están aquí legalmente, entonces en vez de arriesgarse con la policía deciden no venir más a la tienda, y eso me hace mucho daño

INTERVIEWER: Donde compra usted sus productos para vender en su tienda?

PARTICIPANT \#3: Yo compro todos los productos que necesito en un wholesaler en Washington, D.C, es mucho más económico que comprar productos aquí en West Virginia y es relativamente cerca, pero mire señor me tengo que ir faltan muchas preguntas? 
INTERVIEWER: No senora, no se preocupe solo una cosa, conoce usted otros negocios Latinos en West Virginia que de pronto pueda contactar?

PARTICIPANT \#3: Si, hay otra tienda latina aquí en el pueblo, pero a nosotros no nos gusta hablar con ellos, ellos no saben hacer las cosas bien y nos roban los clientes, entonces prefiero no darle información acerca de ellos tampoco a usted

INTERVIEWER: Ok, entiendo, senora $\quad$ muchas gracias y hasta pronto

PARTICIPANT \#3: Con mucho gusto y mucha suerte

\section{Participant \#4 - Survey}

\section{Cuestionario Demográfico*}

Nombre:

Dirección Actual:

Número Telefónico:

Correo Electrónico: N/A

Fecha de Nacimiento: May 7 th, 1971

Lugar de Nacimiento: Ciudad de Mexico,Mexico

\section{Patrones de Residencia:}

Nacido en_Mexico___vivió hasta___ 2002___ Grande, Mediana, Pequeña, Pueblo, Rural Mudado a ___Virginia___vivió hasta___2006____ Grande, Mediana, Pequeña, Pueblo, Rural Mudado a _ _ vivió hasta____ Grande, Mediana, Pequeña, Pueblo, Rural Mudado a vivió hasta Grande, Mediana, Pequeña, Pueblo, Rural

\section{Numero de Hermanas: 1}

Nombre:

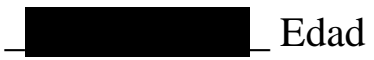
36 Vive en __Mexico

Nombre: Edad Vive en

Nombre: Edad Vive en 
Numero de Hermanos: 2

Nombre:

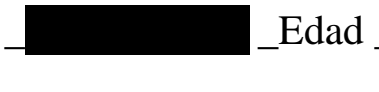

29
Vive en Virginia

Nombre:

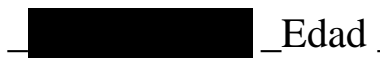
33 Vive en Mexico

Nombre: Edad Vive en

\section{Padres:}

Nombre de la Madre: Muerta Edad Vive en

Nombre del Padre:

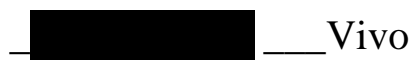
Edad 78 Vive en

Estado Civil de los padres: Viudo

Lugar de nacimiento de la Madre: Mexico

Lugar de nacimiento del Padre: Mexico

Profesión de la Madre: Sin Profesion

Profesión del Padre: Arquitecto

\section{Profesión y Educación:}

Profesión: Commerciante

Nombre del Negocio:

Educación: ___ Colegio

\section{Estado Civil e Historia:}

Estado Civil: Casado

Hijos: DOS

Nombre: N/A Edad Sexo: Masculino

Nombre: N/A Edad: _ 8 Sexo: _Masculino

Nombre: Edad: Sexo: 
Ocupación de Esposa/o: N/A

\section{Religión:}

Denominación: Catolico

\section{Entrevista estructurada para dueño de negocio*}

31. ¿Que tipo de negocio tiene? Restaurante Latino

32. ¿Cuando abrió su negocio? $\underline{\mathbf{2 0 0 6}}$

33. ¿Cual es el ingreso anual del negocio? (a) menos de $\$ 10,000$, (b) 10,000 - $\$ 50,000$, (c) $\$ 50,000$ - \$75,000, (d) \$75,000 - \$100,000 o (e) más de \$100,000.

34. ¿Como selecciono el tipo de negocio que iba a abrir?

35. ¿Tenia usted alguna clase de experiencia previa en negocios? $\underline{\text { No }}$

36. ¿Cual era su ocupación antes de abrir su negocio Pintor

37. ¿Como empezó su negocio? (empezó solo, compro un negocio existente, lo heredo, etc.) $\underline{\text { Con }}$ mi esposa

38. ¿Hace usted alguna clase de mercadeo o propaganda? $\underline{\mathbf{S i} \text {, estoy en las páginas blancas }}$

39. ¿Que hace usted para encontrar clientes nuevos? Cocinar bien!

40. ¿Quienes son la mayoría de sus clientes? (¿son la mayoría Latinos?) Muchos Latinos, y uno que otro Americano que viene a comer

41. ¿Cuántos empleados tiene? cuatro

42. ¿Quienes son sus empleados? familiares

43. ¿Tiene usted una segunda fuente de ingresos? $\underline{\text { No }}$

44. ¿Si usted fuese a empezar un negocio hoy, que haría diferente? Trataría de pedir más ayuda y educarme un poco mas

45. ¿Que consejo le daría a alguien que esta a punto de abrir un negocio? De hacer un muy buen estudio del mercado antes de hacerlo

\section{Entrevista con Preguntas de Financiamiento}


46. ¿Como obtuvo financiamiento para abrir este negocio? De mis ahorros personales

47. ¿Que oficinas gubernamentales o entidades utilizo para obtener financiamiento? Ninguna,no sabía dónde encontrar informacion

48. ¿Esta usted consciente de la cantidad de organizaciones que proveen financiamiento para minorías en West Virginia? Para nada

49. ¿Si usted supiera más información acerca de estas fuentes de financiamiento, habría esto ayudado a comenzar su negocio? No lo sé, pero no creo

50. ¿Fue financiamiento un problema para su negocio? ¿Si lo fue como lo supero? Si no, ¿porque no? No, tenía mis ahorritos

51. ¿Como obtuvo el capital para empezar su negocio? (fondos personales/prestamos familiares/instituciones financieras)

52. ¿Si usted fuera a abrir un negocio hoy en día, a donde iría para financiamiento? No sé, probablemente ahorraría de nuevo, es mejor que deber dinero

53. ¿Cuales fueron algunos de los problemas/dificultades que encontró antes de abrir su negocio? No entendía mucho de regulaciones, y leyes antes de empezarlo, no sabía mucho de negocios en general

54. ¿Cuales son algunos problemas/dificultades que encuentra ahora que ya abrió su negocio?

\section{Poca gente viene, la economía está muy complicada}

55. ¿Cual es su visión para su negocio? ¿Tiene un plan de sucesión? Por ahora no, vamos a ver si sobrevivo esta recesión

56. ¿Planea abrir un segundo negocio o expandir su negocio algún día? No

57. ¿Siente usted que fue fácil obtener fondos (si necesario) para abrir su negocio? No fue necesario

58. ¿Es usted familiar con alguno de los siguientes programas? No, ninguno
a. INNOVA
b. TechConnectWV
c. Biomass Crop Assistance Program
d. Neighborhood Investment Program (NIP)
e. Tax Increment Financing (TIF)
f. Microloan Program 
g. WV Linked Deposit Fund

h. Military Incentive Program (MIP)

i. On the Job Training (OJT)

j. Matching Advertising Partnership Program (MAPP)

k. Recreational Trails Program

1. Scenic Byways Program

m. WVEDA Direct Loan Program

n. Loan Insurance Program

o. Small Business Administration (SBA)

p. Small Business Development Center (SBDC)

59. ¿Cree usted que estos programas son lo suficientemente promocionados en el estado de West Virginia? No

60. ¿Si usted hubiera sabido de algunos de estos programas antes de abrir su negocio, habría esto ayudado a su negocio? No creo, tendría que estudiar bien como ayudan, porque no me gusta que se me metan mucho en mi negocio.

Muchas gracias por su tiempo y ayuda con este proyecto.

¿Estaría usted dispuesto a referirnos a otros Latinos que sean dueños de negocios que podrían ser partícipes de este estudio? $\underline{\text { No conozco ninguno }}$

*Parte de este cuestionario fue informado por McCracken, 1988, p. 67. And Shinnar, Young, 2008 y traducido por el autor.

\section{Participant \#5 - Interview}

PARTICIPANT \#5: Alo?

INTERVIEWER: Buenos días, con quien hablo por favor?

PARTICIPANT \#5: Habla con a quien necesita?

INTERVIEWER: Hola señor como esta? Habla con Juan Arcila, de West Virginia University, yo le envié un email explicándole que la quería entrevistar para mi tesis... 
PARTICIPANT \#5: si como no, como está usted?

INTERVIEWER: muy bien gracias, será que este es un buen momento para hacer la entrevista?

PARTICIPANT \#5: Si, pero tiene que ser corta, tengo solo como 15 minutos, está bien?

INTERVIEWER: Si claro no hay problema, si en algún momento se tiene que ir me avisa y podemos acelerar la entrevista o terminarla después. Primero que todo le quiero decir que usted puede escoger responder la pregunta que quiera, y la que no quiera responder no es para nada obligatoria, usted prefiere hacer la entrevista en español o inglés?

PARTICIPANT \#5: Me sentiría más cómodo en español si no le molesta

INTERVIEWER: no para nada, también le quería informar que esta entrevista está siendo grabada, pero que en ningún momento su identidad será divulgada ni conocida por nadie que lea el estudio, ok?

PARTICIPANT \#5: perfecto

INTERVIEWER: Bueno, entonces empecemos, como es su nombre?

PARTICIPANT \#5: Mi nombre es

INTERVIEWER: Cual es el nombre de su negocio?

PARTICIPANT \#5:

INTERVIEWER: Cuál es su dirección actual?

PARTICIPANT \#5:

INTERVIEWER: Cuál es su número telefónico?

PARTICIPANT \#5: el del restaurante es

INTERVIEWER: Cuál es su dirección de correo electrónico?

PARTICIPANT \#5: mi e-mail es

INTERVIEWER: Cuál es su fecha de Nacimiento?

PARTICIPANT \#5: Enero 5, 1972

INTERVIEWER: Cuál es su lugar de nacimiento?

PARTICIPANT \#5: Monterrey, México

INTERVIEWER: Cuantos hermanos/as tiene y donde viven?

PARTICIPANT \#5: Tengo 3 hermanos hombres, todos salimos hombres, jaja pobrecita mi mama INTERVIEWER: jaja, y sus padres donde nacieron? 
PARTICIPANT \#5: Mis padres son ambos Mexicanos

INTERVIEWER: Y cuál era la profesión de sus padres?

PARTICIPANT \#5: Mi papa trabajaba en construcción, y mi mama trabajaba como abogada

INTERVIEWER: Es usted casado?

PARTICIPANT \#5: Si soy casado y tengo dos hijos

INTERVIEWER: Usted ha ido a la universidad?

PARTICIPANT \#5: no, termine el colegio y después perdí un poco la motivación para seguir estudiando INTERVIEWER: Que tipo de negocio tiene ahora?

PARTICIPANT \#5: Tengo un restaurante Mexicano

INTERVIEWER: Cuando abrió su negocio?

PARTICIPANT \#5: Yo abrí mi negocio en el 2002

INTERVIEWER: Cual es el ingreso anual de su negocio?

PARTICIPANT \#5: mmmm, usted me dijo que no tenía que responder a lo que no quería responder cierto?

INTERVIEWER: Si señor por supuesto

PARTICIPANT \#5: Entonces prefiero no responder esa pregunta, es un poco muy personal.

INTERVIEWER: Bueno no hay problema, podemos seguir con la próxima pregunta, tiene usted alguna clase de experiencia con tener negocios y manejarlos?

PARTICIPANT \#5: Pues de cómo manejarlos antes de este trabajo no mucho, pero definitivamente he tenido la experiencia de trabajar en un restaurante que tenía un tío en México y eso me ayudó mucho para abrir este negocio

INTERVIEWER: Fue usted parte de algún programa del gobierno cuando estaba abriendo su negocio? Recibió algún tipo de ayuda gubernamental?

PARTICIPANT \#5: No, para nada, el gobierno acá por lo que nos han contado se aprovecha de uno, más que todo cuando uno es Latino, entonces eso es mejor no llamarlos o involucrarlos.

INTERVIEWER: Es usted el dueño de su negocio completamente? O tiene un socio?

PARTICIPANT \#5: Pues comparto el negocio con mi esposa, pero lo manejo yo

INTERVIEWER: Usted hace algún tipo de mercadeo o publicidad? 
PARTICIPANT \#5: si, siempre mando a imprimir muchos volantes y cosas asi para que la gente venga a visitar el restaurante, adicionalmente tengo especiales y promociones todos los dias de semana para atraer más gente

INTERVIEWER: Es la mayoría de sus clientes Latino?

PARTICIPANT \#5: Pues tengo bastantes clientes del área, y bastantes clientes Latinos, pero es una mezcla de todo

INTERVIEWER: Cuantos empleados tiene?

PARTICIPANT \#5: Tengo 4 empleados y eso incluye a mis hijos.

INTERVIEWER: Bueno, no le quiero quitar mucho tiempo, entonces le quiero hacer solo un par de preguntas más, qué consejo le daría a otros individuos Latinos en West Virginia que quieren empezar un negocio?

PARTICIPANT \#5: Pues les diría que lo abran con mucha conciencia. Es Importante saber que uno le tiene que meter el corazón y el alma al negocio para poder sacar algo positivo, porque si no es la clase de cosa que se lo puede comer vivo a uno. Pero si uno lo ama, y trabaja duro puede ver los resultados positivos que uno espera siempre ver, yo todavía estoy esperando jajaja

INTERVIEWER: $Y$ como hizo usted para conseguir financiamiento para empezar su negocio?

PARTICIPANT \#5: Pues la verdad es que nos ayudó mucho la familia y ahorros que teníamos desde antes de venirnos de México, lo bueno es que no tuvimos que pedir préstamos ni nada por el estilo porque si no estaríamos todavía en procesos para ver quién nos daba un crédito

INTERVIEWER: Y por último, conoce usted otros negocios Latinos en West Virginia que de pronto pueda contactar?

PARTICIPANT \#5: Pues yo he visto un par de negocios, pero la verdad es que no conozco a los dueños personalmente, lo siento mucho

INTERVIEWER: No hay problema señor muchas gracias y hasta pronto

PARTICIPANT \#5: Con gusto, chao

\section{Participant \#6 - Survey}

\section{Demographic Questionnaire*}

Name:

Current Address:

Phone: 
Email:

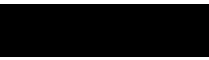

Birth Date: ___ June $19^{\text {th }}, 1969$

Birth Place ___ Guadalajara, Mexico

\section{Residence Pattern:}

Born in ___ Mexico__ until __ 2000__ big, medium, little, village, rural

Moved to ___ West Virginia___ until___ big, medium, little, village, rural

Moved to until big, medium, little, village, rural

Moved to until big, medium, little, village, rural

\section{Sisters: 1}

First Name: present age 38 now lives in ___ Miami

First Name: present age now lives in

First Name: present age now lives in

Brothers: 0

First Name: present age now lives in

First Name: present age now lives in

First Name: present age now lives in

\section{Parents:}

Mother's name: present age 73 now lives in Mexico

Father's name: present age 76 now lives in Mexico 
Marital Status: ___ Divorced

Mother's place of birth: ___ Mexico

Father's place of birth:___ Mexico

Occupation of mother: ___Unemployed

Occupation of father: ___ Retired

\section{Occupation and Education:}

Occupation:_Business owner

Company:

Education: High School

Marital Status and History:

Marital Status: ___Married

Children: 2

Name:

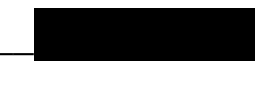

Age:_1

Gender:__

Name:

Age:__16__ Gender:

F

Name:

Age: Gender:

Occupation of Spouse: Accountant

\section{Religion:}

Denomination: No association

\section{Semi-Structured Business Owner Interview*}

31. What type of business do you own? Grocery Store

32. When did you open your business? $\underline{\mathbf{2 0 0 4}}$ 
33. What are your annual gross sales? (a) less than 10,000 , (b) $10,000-50,000$, (c) 50,000 75,000, (d) 75,000-100,000or (e) 100,000 and over. Not comfortable answering

34. How did you select the type/line of business? Saw an opportunity, I like to think it selected me

35. Did you have any prior business experience? I did, I had worked in a family business before

36. What was your occupation prior to current business? Worked at another grocery store growing up

37. How did you start your business? (Self-started, bought existing business, inherited, etc.) I started it because I had worked in one for a while and thought I could do it on my own, I opened it alone

38. Do you do any marketing/advertising? I do not

39. What do you do in order to find new customers? I provide specials and promotions for the people that shop at the store

40. Who are the majority of your clients/customers (are they mostly Latino?) They are mostly Latinos that work in the area, I do not get a lot of other clients

41. How many employees do you have? I have 3 employees, it's a small operation

42. Who are your employees? My kids, and a cousins

43. Do you have a second source of income? My wife's salary

44. If you were to start a business today, what would you do differently? I would have chosen a difference location, both city and place in the city, I am located in a bad part of town and my business suffers because of it

45. What advice would you give someone who was about to open a business? To be 100 percent sure that they want to do it, because their business will become their lives

46. How did you obtain funding for this business venture? Personal savings and salary from my wife's job

47. What governmental offices or entities did you go to in order to reach out for funding? None

48. Are you aware of the several organizations that provide funding for minorities in West Virginia, If so which ones? No, but I didn't really look for any, I was not interested in getting any government or outsiders involved in the process, I don't really trust them

49. If you knew more information about these funding sources, would that have helped your business getting started? It would not have made a difference

50. Was funding ever an issue for your business venture? Is so, how did you surpass it? If not, why not? It was never an issue

51. How did you obtain start-up capital? (Personal funds/family loans/financial institutions) No loans of financial institutions. No, I was very sure of what I was doing; I never wanted to find any funding because I would have to spend my entire life paying for it

52. If you were going to open a business today, where would you go for financing?

53. What were some of the problems/difficulties you encountered before you opened your business? It was difficult to do all the paperwork of obtaining and securing the location

54. What are some of the problems/difficulties you encounter now, as you are running it? 
55. What is your vision for your business? Do you have a succession plan? I would like my children to take over someday, I have them working with me on a regular basis

56. Are you planning on opening another business or expanding your current one? $\underline{\text { I am, but not }}$ here, maybe in another place

57. Do you feel that funding (if necessary) was easy to obtain? Yes, but only because I had the discipline to save up

58. Are you familiar with any of these programs? I have heard of INNOVA, but I don't think that would have helped me

a. INNOVA

b. TechConnectWV

c. Biomass Crop Assistance Program

d. Neighborhood Investment Program (NIP)

e. Tax Increment Financing (TIF)

f. Microloan Program

g. WV Linked Deposit Fund

h. Military Incentive Program (MIP)

i. On the Job Training (OJT)

j. Matching Advertising Partnership Program (MAPP)

k. Recreational Trails Program

1. Scenic Byways Program

m. WVEDA Direct Loan Program

n. Loan Insurance Program

o. Small Business Administration (SBA)

p. Small Business Development Center (SBDC)

59. Do you think that these programs are being promoted and advertised enough in the state of West Virginia? Not really, I had not even heard of most of them, almost none of them

60. If you had any prior knowledge about any of these programs before opening your business, would that have helped your business? Maybe, I guess we'll never know

Thank you for your time and help with this project.

Would you be willing to refer us to another Latino small business owner who you think would be willing to participate in our study? I would, but I do not know any other business owners

*Parts of this questionnaire are informed by McCracken, 1988, p. 67. And Shinnar, Young, 2008. 


\section{$\underline{\text { Participant \#7 - Interview }}$}

PARTICIPANT \#7: Hello

INTERVIEWER: how are you doing? This is Juan Arcila

PARTICIPANT \#7: Hello again, I am glad we can finally sit down and get this interview done

INTERVIEWER: Tell me about it! You and me both! Thank you by the way for making some space for me on your busy schedule

PARTICIPANT \#7: No problem, it's a pleasure, any way I can help

INTERVIEWER: Alright, let's go ahead and jump right in it then, so first of all, I would like to let you know that this conversation is being recorded but in no way will your name, the name of your business, or any kind of figures will be published, it will all be anonymous, are we clear?

PARTICIPANT \#7: Crystal

INTERVIEWER: So first of all, would you like me to do the interview in English or Spanish?

PARTICIPANT \#7: English works for me

INTERVIEWER: Alright, could you please state your full name and last name?

PARTICIPANT \#7:

INTERVIEWER: What's your phone number?

PARTICIPANT \#7:

INTERVIEWER: Your Email address?

PARTICIPANT \#7:

INTERVIEWER: What is your current mailing address?

PARTICIPANT \#7:

INTERVIEWER: Another thing, if at any point you feel uncomfortable by any of the questions you can go ahead and say you do not want to answer it and I will skip that question and move on to the next one. Ok?

PARTICIPANT \#7: ok

INTERVIEWER: What is your birth date?

PARTICIPANT \#7: April $25^{\text {th }}, 1979$

INTERVIEWER: What is your birth place? 
PARTICIPANT \#7: I was born in the great country of Mexico

INTERVIEWER: Where in Mexico?

PARTICIPANT \#7: In Atahualpa

INTERVIEWER: When did you move to the U.S?

PARTICIPANT \#7: I moved about 8 years ago

INTERVIEWER: Did you move directly to West Virginia?

PARTICIPANT \#7: No, I actually went to Georgia first, and then West Virginia

INTERVIEWER: And what made you move to West Virginia?

PARTICIPANT \#7: Let's just say I knew some people that wanted to me to come and be here in the state with them

INTERVIEWER: Gotcha, how many sisters and brothers do you have?

PARTICIPANT \#7: I have two little sisters, I'm the old one!

INTERVIEWER: And were both your parents born in Mexico as well?

PARTICIPANT \#7: My mother was, my father was born in Guatemala

INTERVIEWER: What do you currently do for a job?

PARTICIPANT \#7: I have my own business advice center

INTERVIEWER: Are you married?

PARTICIPANT \#7: No, I am single

INTERVIEWER: Do you have any children?

PARTICIPANT \#7: I do not! Not for a while I hope!

INTERVIEWER: When did you open your business?

PARTICIPANT \#7: 2007

INTERVIEWER: What are your annual gross sales?

PARTICIPANT \#7: mmm, let's move on to the next question...

INTERVIEWER: Ok, how did you select the type of business that you wanted to open?

PARTICIPANT \#7: Because I just saw a need for it, there are a lot of people out there that do not know what they need to do in order to start a business or even that the possibility is there, also I just think that it is important for these people to hear the experience that I had when I started my first business 
with just very little money. I am a big believer in the power of the mind, and I believe I can help these people start a successful business by showing them how to work together and use the power of their mind

INTERVIEWER: Did you have any prior business experience?

PARTICIPANT \#7: Not really

INTERVIEWER: What was your occupation prior to opening your business?

PARTICIPANT \#7: I was a student

INTERVIEWER: Do you do any marketing/advertising?

PARTICIPANT \#7: I try, but mostly I just talk to people about it, and hope that other people talk good about me

INTERVIEWER: Ok, what do you do in order to find new customers?

PARTICIPANT \#7: I help people with their businesses, and if they are successful then other clients will come and find me

INTERVIEWER: Are the majority of your clients Latino?

PARTICIPANT \#7: I haven't actually had a Latino client yet, but I would love the possibility to help some Latinos with their businesses, there are just not many out here

INTERVIEWER: Do you have any employees?

PARTICIPANT \#7: nope, one woman operation

INTERVIEWER: Do you have a second source of income?

PARTICIPANT \#7: No, that would force me to become complacent and I need to have the motivation to work hard at this

INTERVIEWER: If you were to start a business today, what would you do differently?

PARTICIPANT \#7: I don't know; probably take some of the advice I give out now to people starting their businesses, like making a solid business plan, that's a big one

INTERVIEWER: What advice would you give someone who was about to open a business?

PARTICIPANT \#7: To forget about life as they know it, and just dive in

INTERVIEWER: How did you obtain funding for this business venture?

PARTICIPANT \#7: I had some savings and made some good money out of a couple of investments

INTERVIEWER: So it was all personal? You did not get a loan?

PARTICIPANT \#7: Oh my goodness no! I did not want that hanging over my head 
INTERVIEWER: So you didn't go to any governmental offices or entities in order to reach out for any other advice?

PARTICIPANT \#7: No, no, I don't really feel like they are helping you with their best interest in mind and selflessly, I always feel like there is something there, like a debt that I would later have to pay with increased interests.

INTERVIEWER: Do you think that maybe if you had more information about governmental entities that would have helped you opening your business?

PARTICIPANT \#7: mmmm not really, like I said, I am not a big fan of governmental entities

INTERVIEWER: What are some of the problems that you encounter in West Virginia?

PARTICIPANT \#7: Well, I don't have a lot of customers, I think that the economic state of the nation really affects people trying to open new businesses and their willingness to pay for business advice, but I am hoping things will turn around soon

INTERVIEWER: What's the biggest advantage that you have over someone that has a regular job?

PARTICIPANT \#7: Autonomy, the fact that I am my own boss, the fact that I can definitely rip the benefits of the work I out in

INTERVIEWER: have you encountered any obstacles as a Latina in West Virginia?

PARTICIPANT \#7: I have had absolutely no obstacles whatsoever, I have had a great experience with my business and would recommend it to anybody that is looking to start one of their own

INTERVIEWER: One last thing, do you know any other Latino business owners in the state?

PARTICIPANT \#7: no I do not, sadly I have not been able to meet any Latino individuals here that have their own businesses

INTERVIEWER: Alright, well I appreciate your time, and wish you good luck in the future of your business venture and thank you

PARTICIPANT \#7: no problem, it was my pleasure, have a good day.

\section{Participant \#8 - Survey}

\section{Demographic Questionnaire*}

Name:

Current Address:

Phone: 
Email:

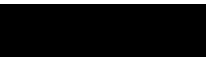

Birth Date: ___ August $10^{\text {th }}, 1964$

Birth Place ___ Veracruz, Mexico

\section{Residence Pattern:}

Born in ___ Mexico__ until___2003___ big, medium, little, village, rural

Moved to ___ West Virginia___ until___ big, medium, little, village, rural

Moved to until big, medium, little, village, rural

Moved to until big, medium, little, village, rural

\section{Sisters: 2}

First Name: present age 42 now lives in __Mexico City

First Name: present age 45 now lives in_South Carolina

First Name: present age now lives in

Brothers: 0

First Name: present age now lives in

First Name: present age now lives in

First Name: present age now lives in

\section{Parents:}

Mother's name: deceased present age now lives in

Father's name: __deceased present age now lives in Marital Status: __ N/A 
Mother's place of birth: ___ Mexico

Father's place of birth:___ Mexico

Occupation of mother: __ N/A

Occupation of father: ___ N/A

\section{Occupation and Education:}

Occupation:_Entrepreneur

Company:

Education: High School degree

Marital Status and History:

Marital Status: __ Widowed

Children: 2

Name:

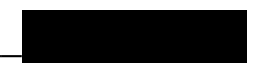

Age:_15

Gender: __F

Name: Age: __13__ Gender: ___ F__

Name:

Age: Gender:

Occupation of Spouse: N/A

\section{Religion:}

Denomination: Catholic

\section{Semi-Structured Business Owner Interview*}

Interviewer: Introduce yourself and explain objective of the research and importance/contribution of participation. Begin with consent form and request permission to tape-record. 
31. What type of business do you own? Children's Day Care

32. When did you open your business? 2006

33. What are your annual gross sales? (a) less than 10,000 , (b) $10,000-50,000$, (c) 50,00075,000, (d) 75,000-100,000or (e) 100,000 and over.----

34. How did you select the type/line of business? Kids in my school did not have a day care before they were old enough to come to school

35. Did you have any prior business experience? Never

36. What was your occupation prior to current business? I was an elementary school teacher

37. How did you start your business? (Self-started, bought existing business, inherited, etc.) Selfstarted

38. Do you do any marketing/advertising? I print out flyers and place them around town and message boards

39. What do you do in order to find new customers? I am actually full right now, so I don't need any new customers

40. Who are the majority of your clients/customers (are they mostly Latino?) Kids that go to the same school were I taught, they are not Latino

41. How many employees do you have? Just me and my sister

42. Who are your employees? See above

43. Do you have a second source of income? Nope, that's it

44. If you were to start a business today, what would you do differently? I would have started it sooner

45. What advice would you give someone who was about to open a business? To look for a need and fulfill it

46. How did you obtain funding for this business venture? Did not need a big investment, I use my home

47. What governmental offices or entities did you go to in order to reach out for funding? ----

48. Are you aware of the several organizations that provide funding for minorities in West Virginia, If so which ones? No, but I never looked

49. If you knew more information about these funding sources, would that have helped your business getting started? Not at all

50. Was funding ever an issue for your business venture? Is so, how did you surpass it? If not, why not? $\underline{\text { No }}$

51. How did you obtain start-up capital? (Personal funds/family loans/financial institutions) See above

52. If you were going to open a business today, where would you go for financing? I would try to not use outside financing

53. What were some of the problems/difficulties you encountered before you opened your business? I really had very little problems, it was a simple business to start

54. What are some of the problems/difficulties you encounter now, as you are running it? Maybe the fact that have more kids than anticipated 
55. What is your vision for your business? Do you have a succession plan? I think I am going to keep my business for another 10 years or so, and then I will just close it down, retire, and enjoy the fruit of my hard work

56. Are you planning on opening another business or expanding your current one? No

57. Do you feel that funding (if necessary) was easy to obtain? $\underline{\mathbf{N} / \mathbf{A}}$

58. Are you familiar with any of these programs? Never heard of any of them
a. INNOVA
b. TechConnectWV
c. Biomass Crop Assistance Program
d. Neighborhood Investment Program (NIP)
e. Tax Increment Financing (TIF)
f. Microloan Program
g. WV Linked Deposit Fund
h. Military Incentive Program (MIP)
i. On the Job Training (OJT)
j. Matching Advertising Partnership Program (MAPP)
k. Recreational Trails Program
1. Scenic Byways Program
m. WVEDA Direct Loan Program
n. Loan Insurance Program
o. Small Business Administration (SBA)
p. Small Business Development Center (SBDC)

59. Do you think that these programs are being promoted and advertised enough in the state of West Virginia? I guess not, I had never heard of them

60. If you had any prior knowledge about any of these programs before opening your business, would that have helped your business? No, it would have not change a thing

Thank you for your time and help with this project.

Would you be willing to refer us to another Latino small business owner who you think would be willing to participate in our study? Don't know any Latino business owners

*Parts of this questionnaire are informed by McCracken, 1988, p. 67. And Shinnar, Young, 2008. 


\section{APPENDIX 8}

Defense Presentation
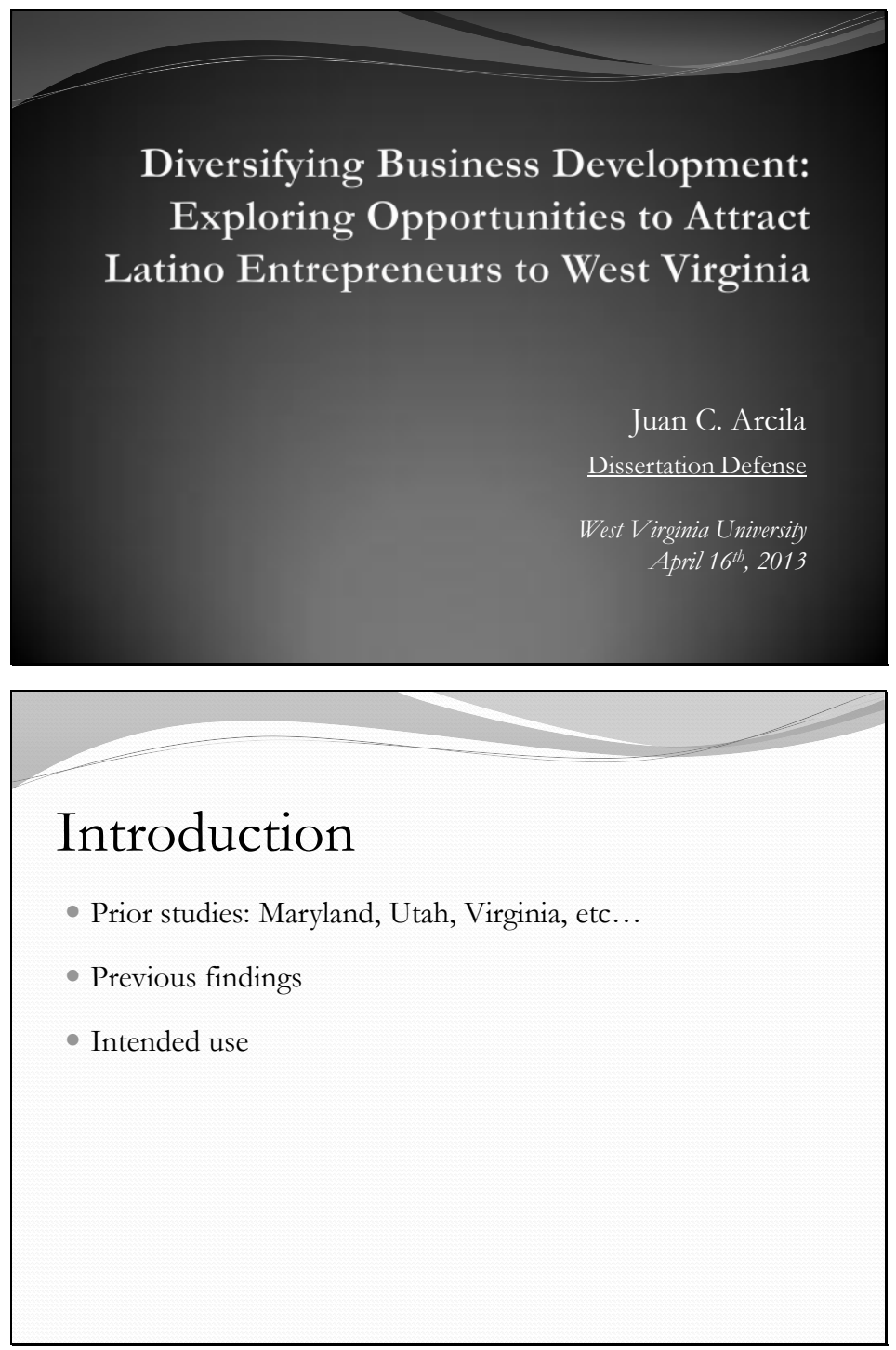


\section{Economic Imperative}

- 2.3 Million Latino-owned businesses in 2007

$\$ 345.2$ billion total

$\$ 150,086.96$ per business average

- Growth comparison

- Importance of growth

\section{Latino Businesses Concentration}

- Location

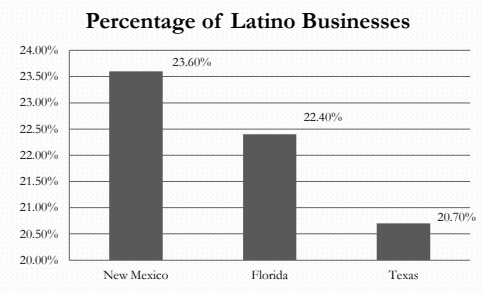

Figure 2. Percentage of Latino Businesses Concentration in Three Major States (Arcila 2012) 

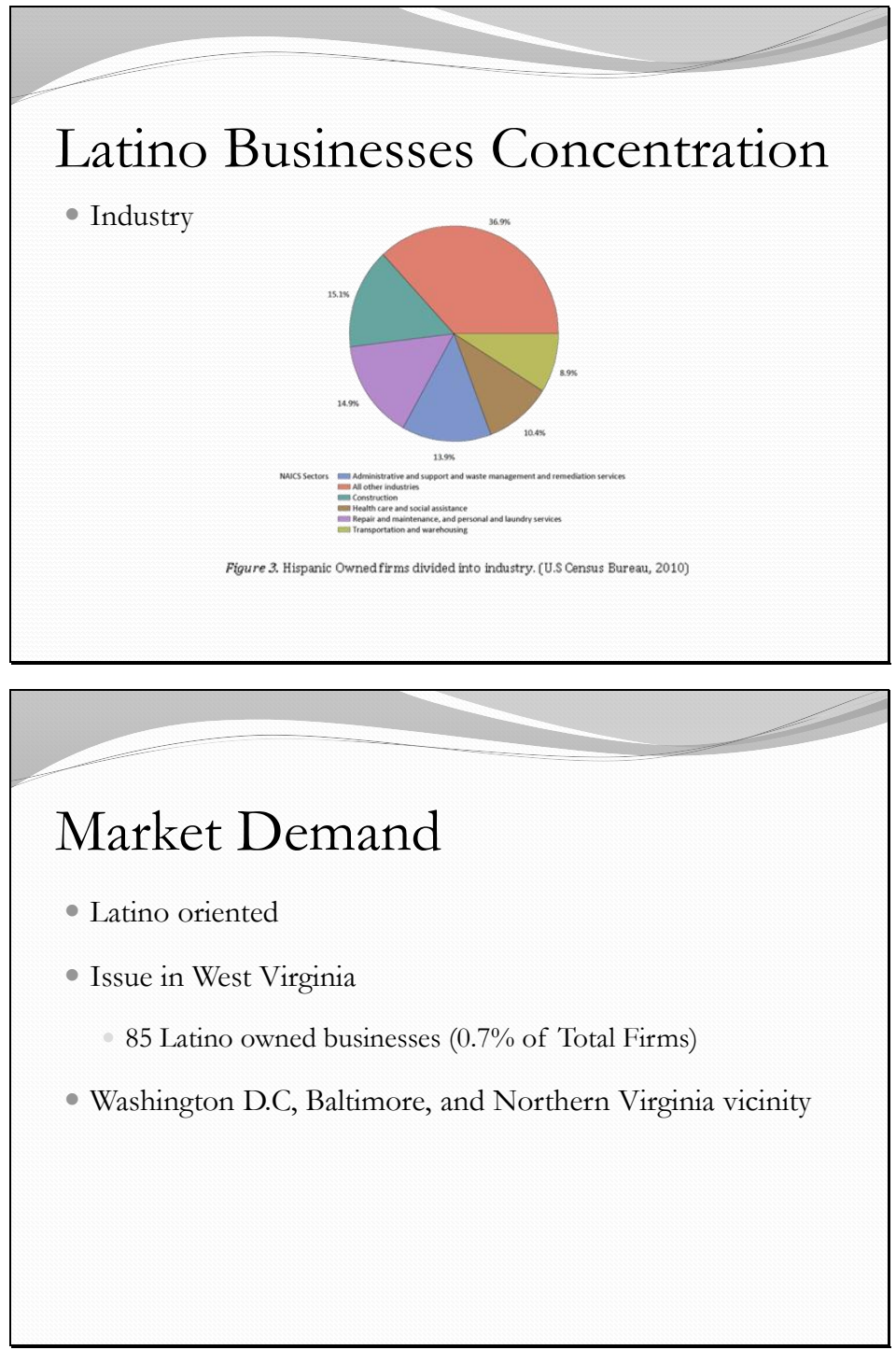

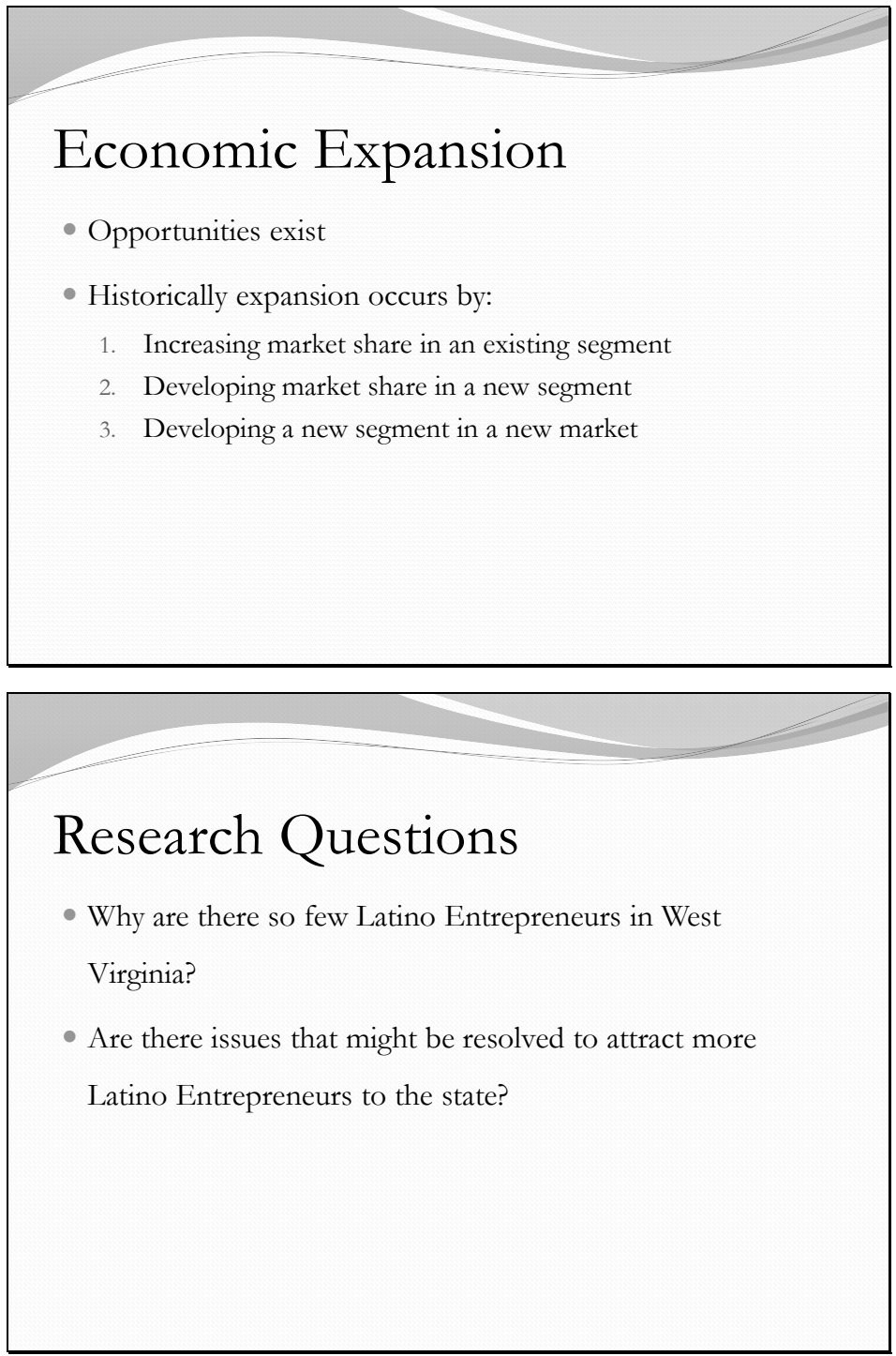

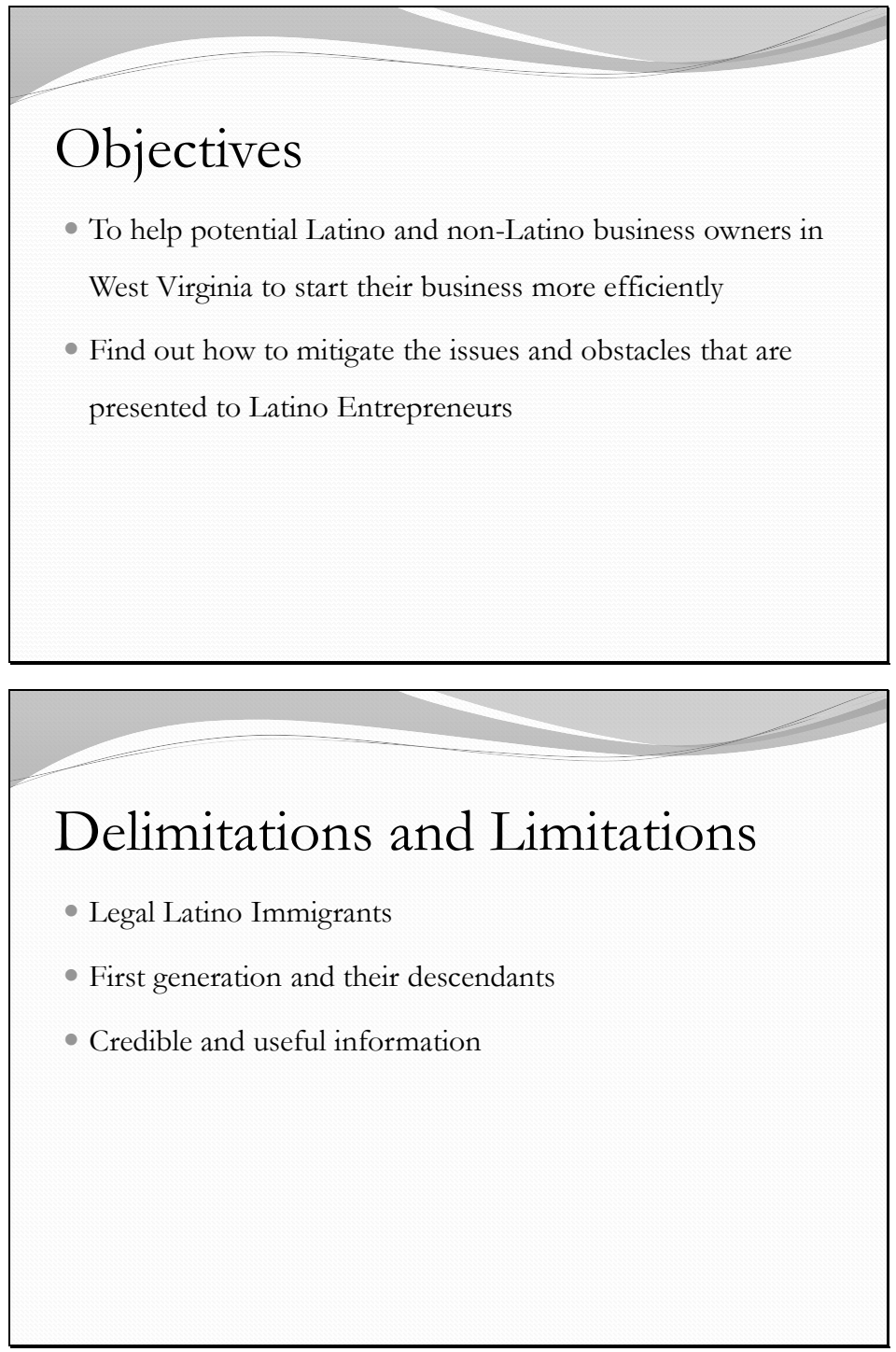


\section{Definitions}

- Entrepreneurship

- Hispanic - Latino

- Legal First Generation Immigrant

- Descendant

- West Virginia Enterprise

\section{Population Background}

- Fastest growing demographic

- West Virginia small population

- Population concentration

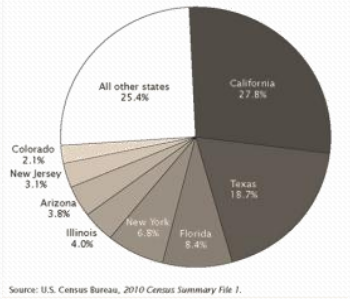

Figure 4 - Percent distribution of highly Hispanic populated states. (U.S Census Bureau 2010 

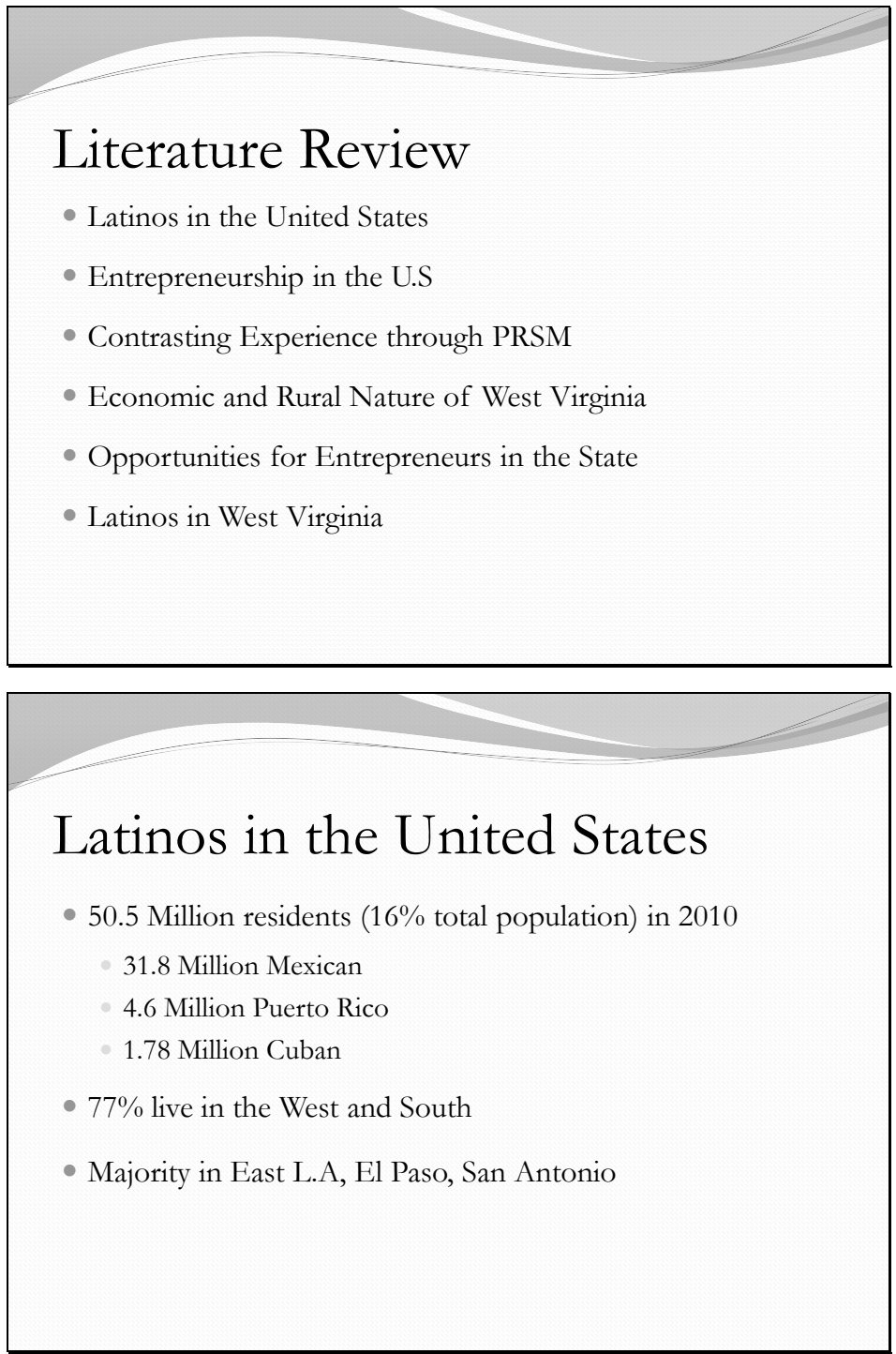

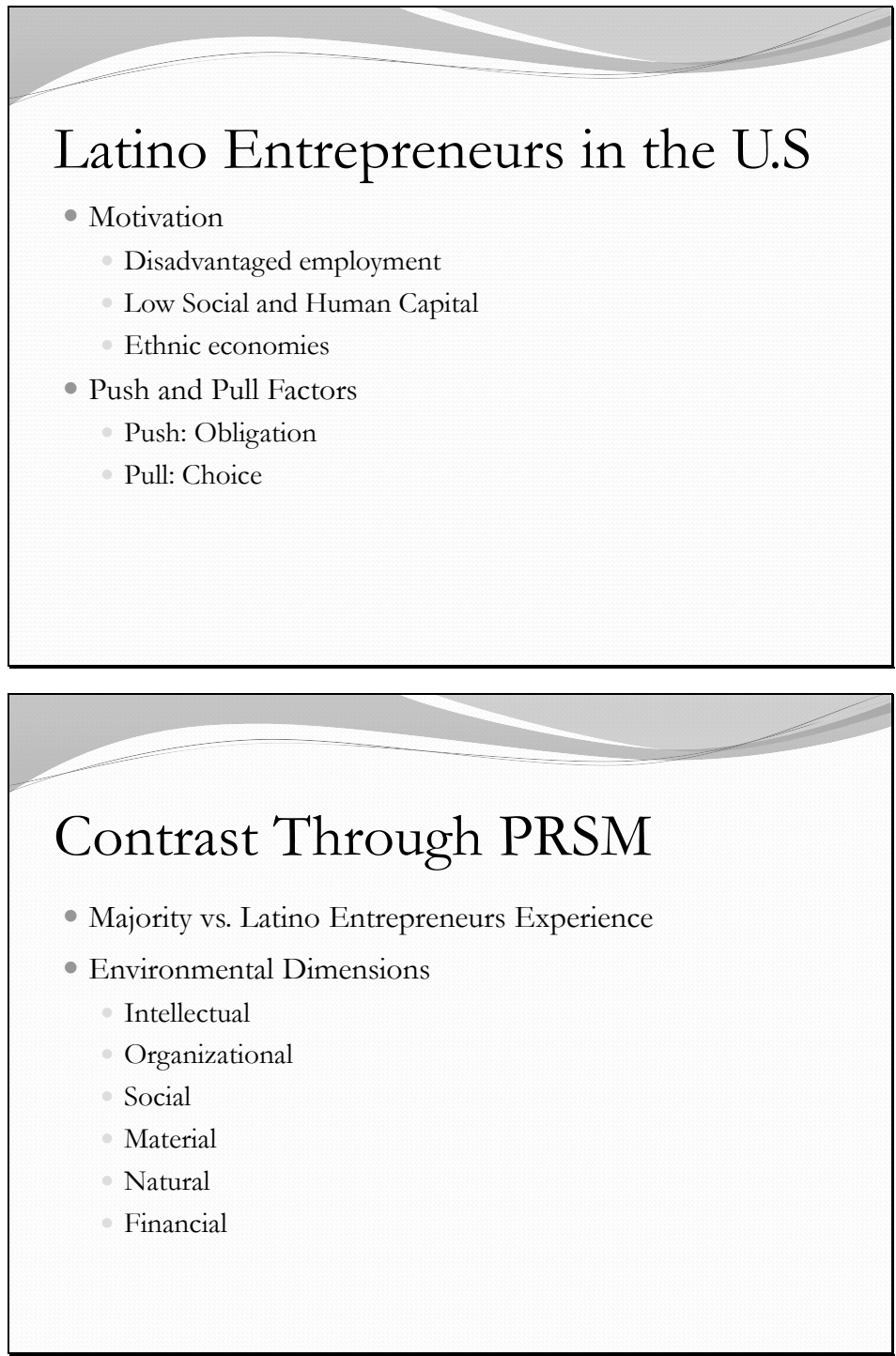


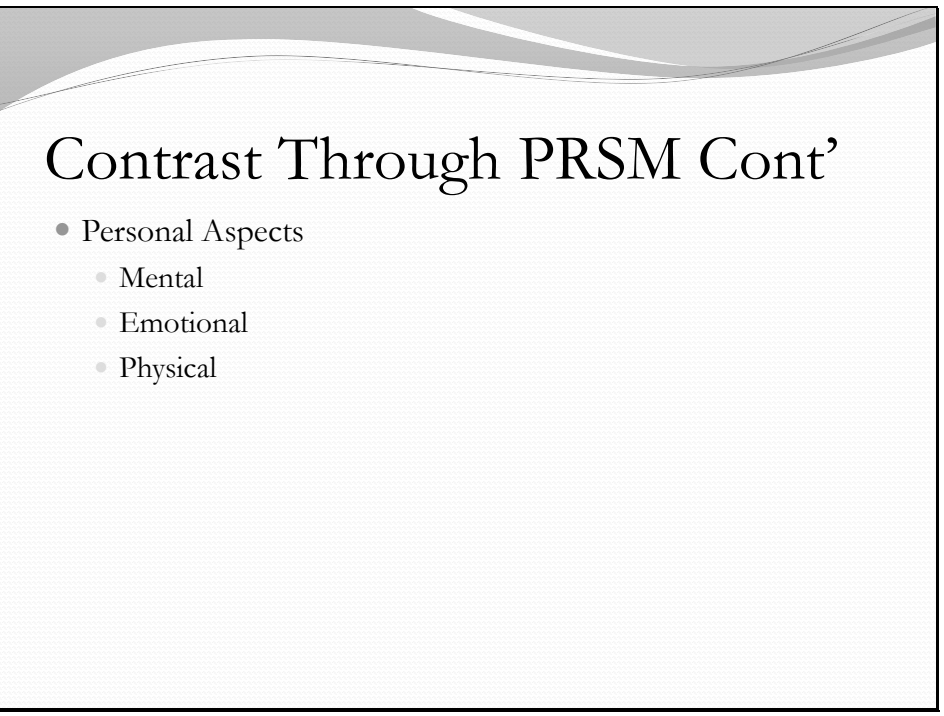

Successful Entrepreneurship
- Definition of Success
- Survival Rates
$48.8 \%$ of the new establishments started between 1977 and
2000 were alive at age five (Shane, 2009)
$29 \%$ of new business ventures started between 1992 and
2002 were alive after a ten year period (Shane, 2008)
Literature on Successful Entrepreneurs



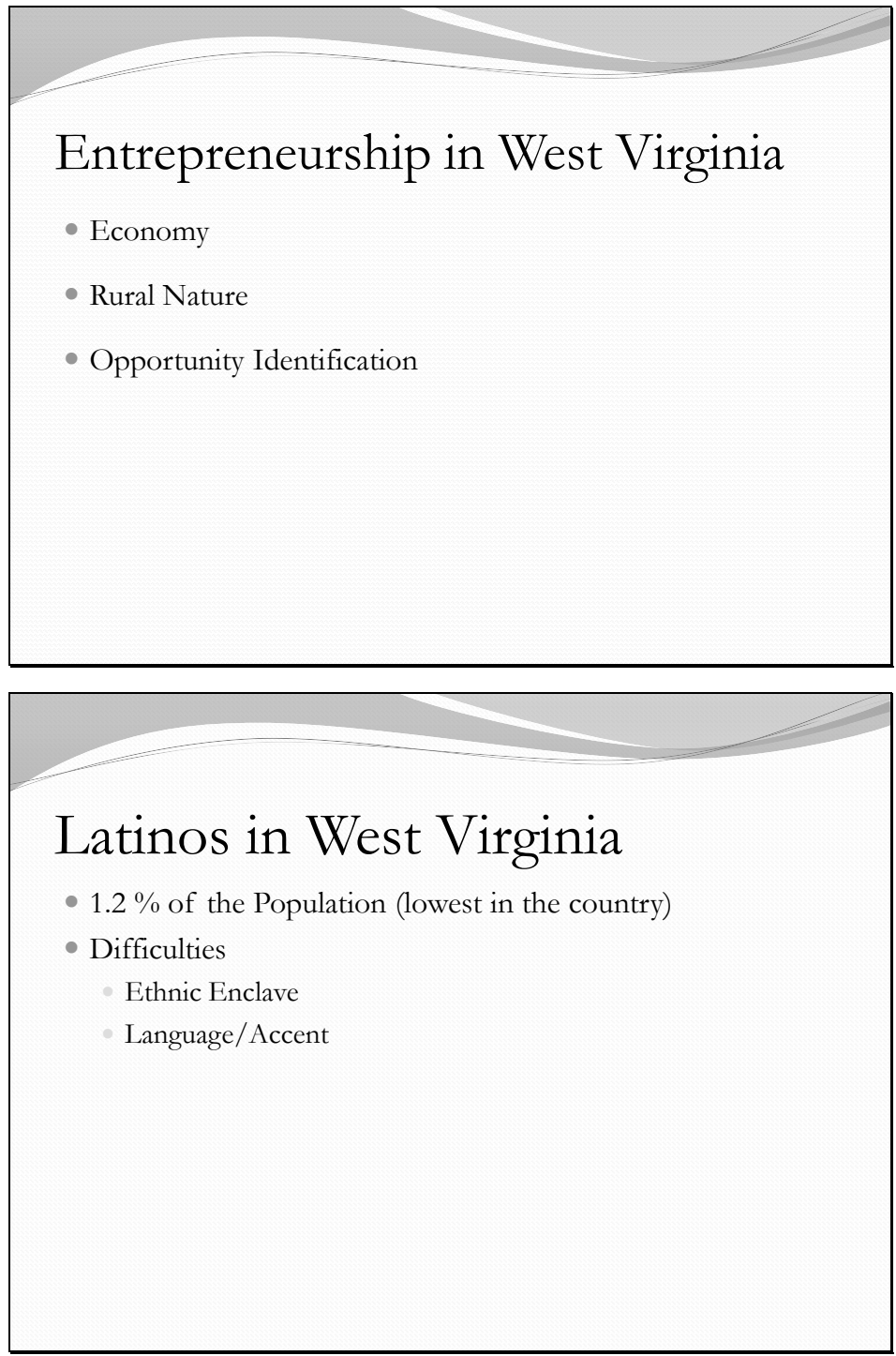

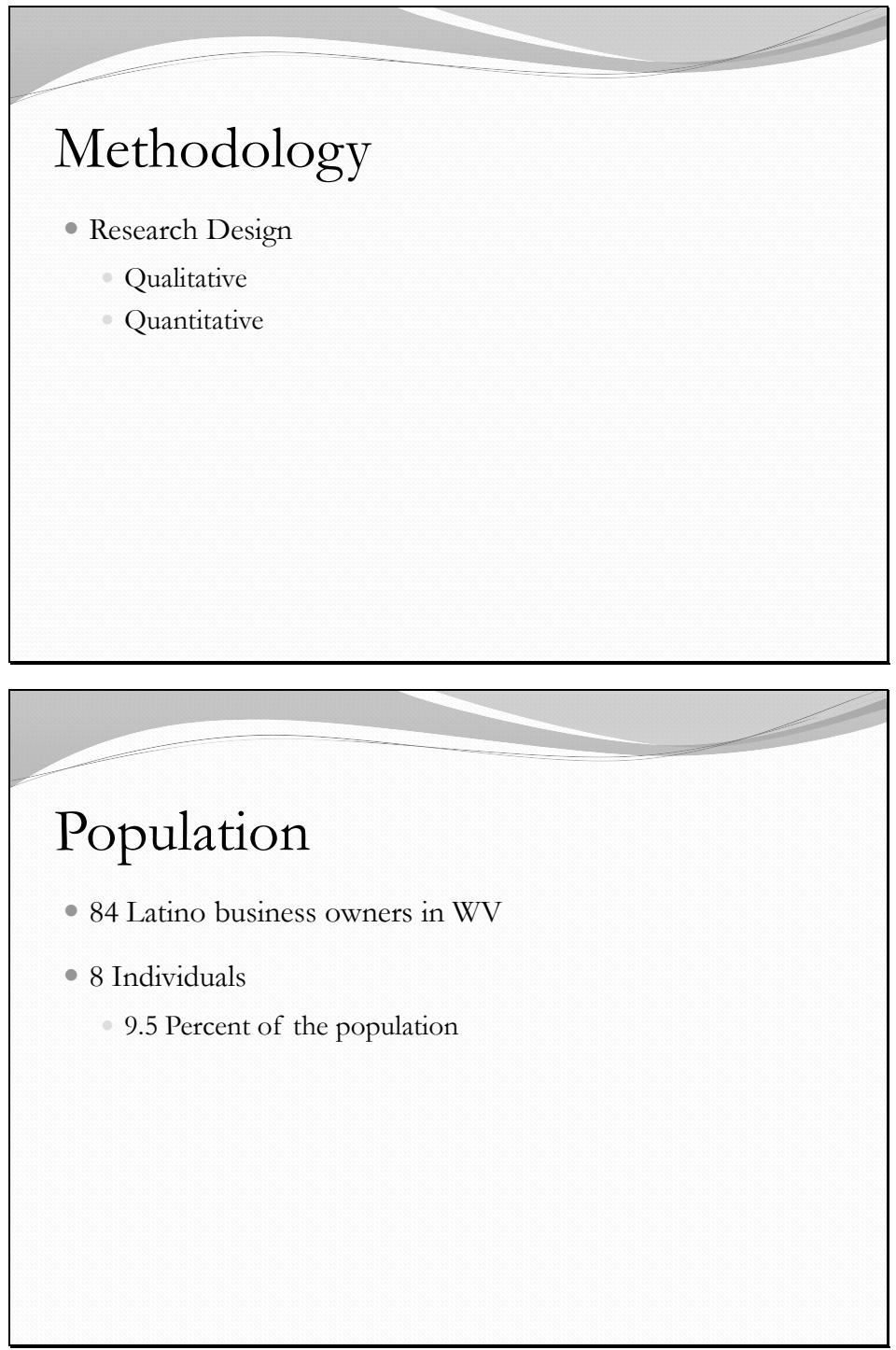

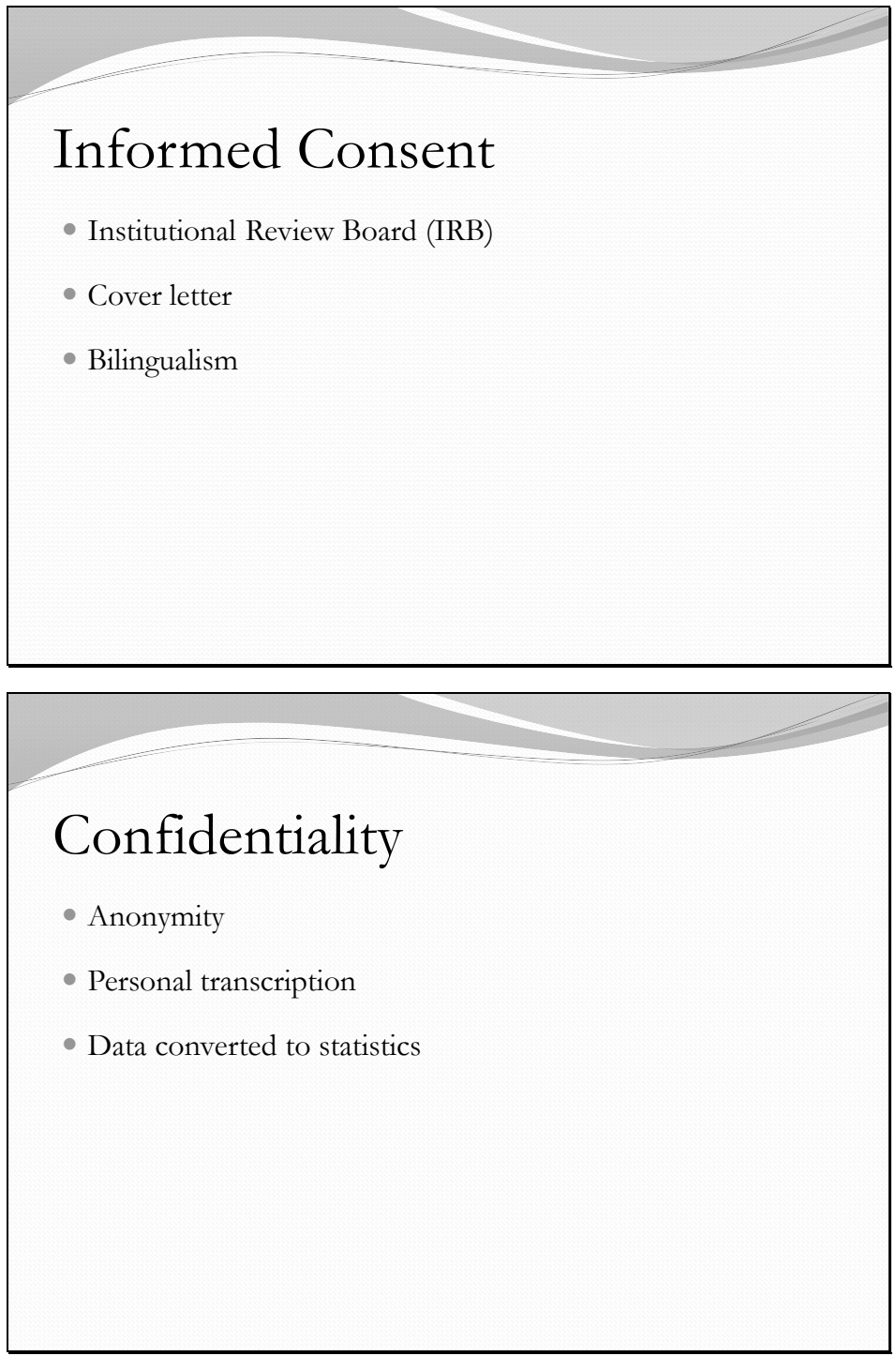

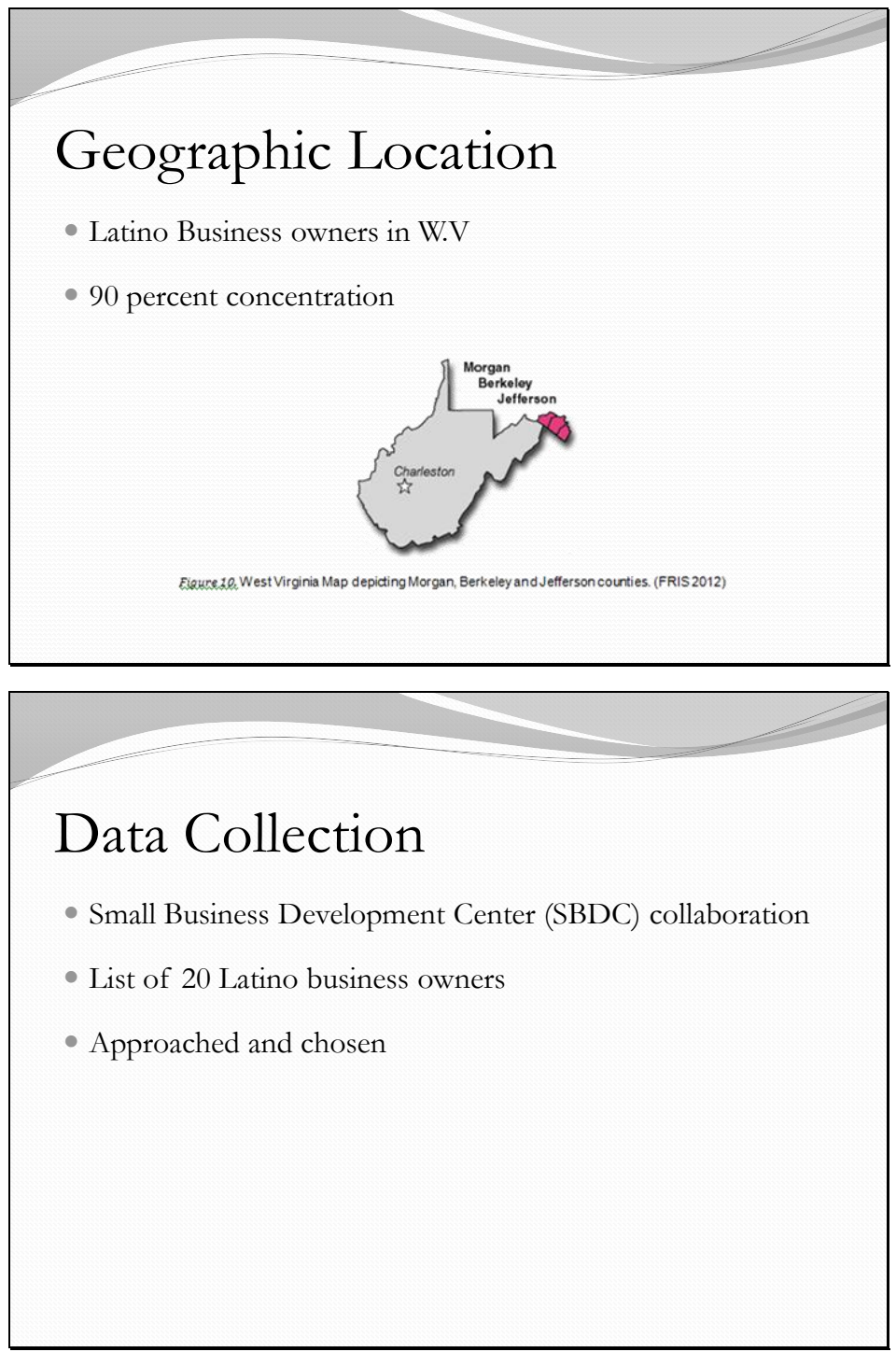

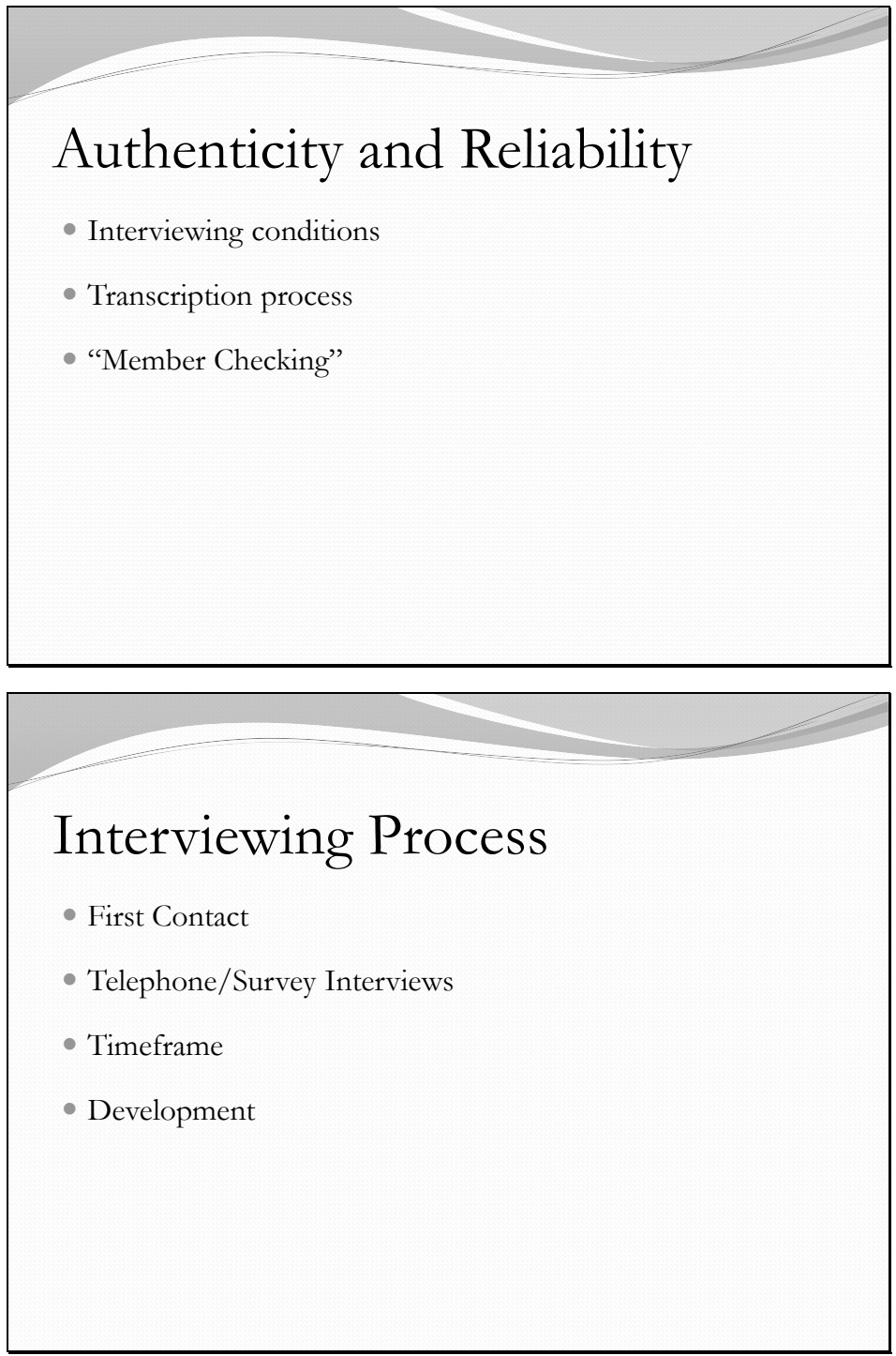


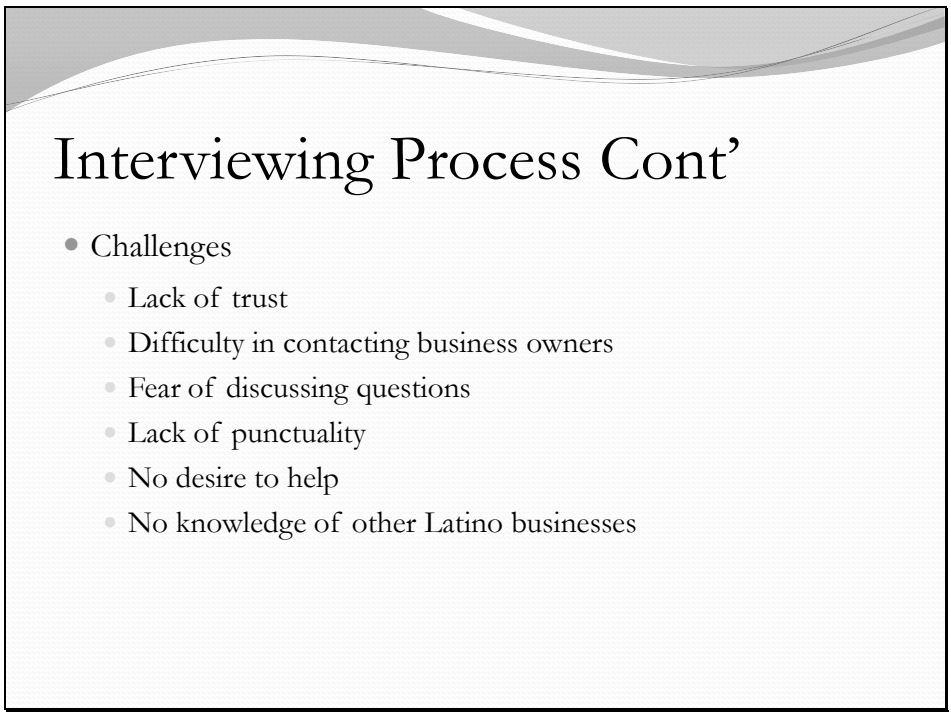

\begin{tabular}{|ll|}
\hline Results and Findings \\
- Participant Description & Length of stay in the U.S \\
Gender & Language abilities \\
Ownership & Family conditions \\
Age & Religion \\
Education & Previous Work Experience \\
& \\
& \\
\end{tabular}



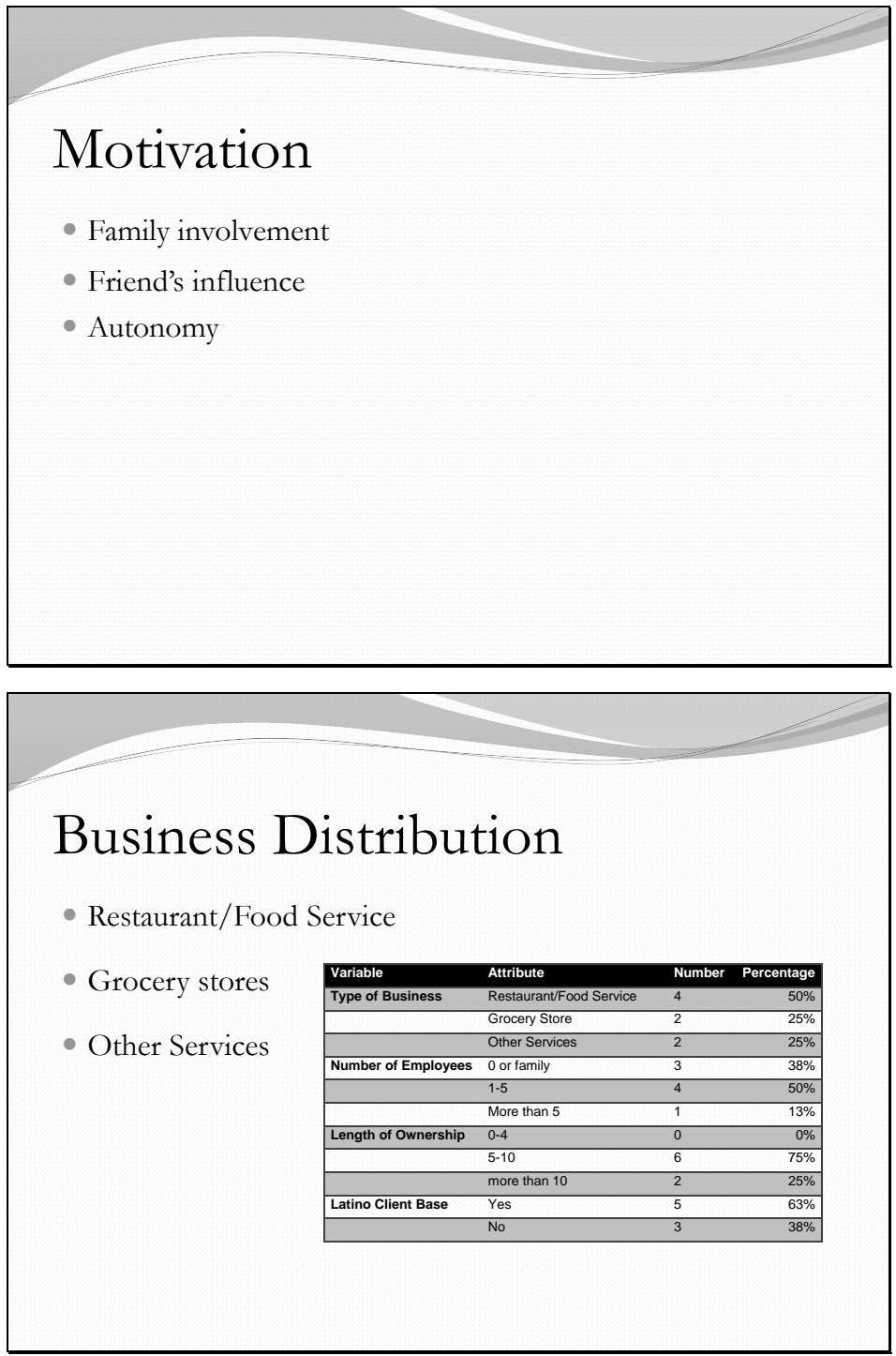

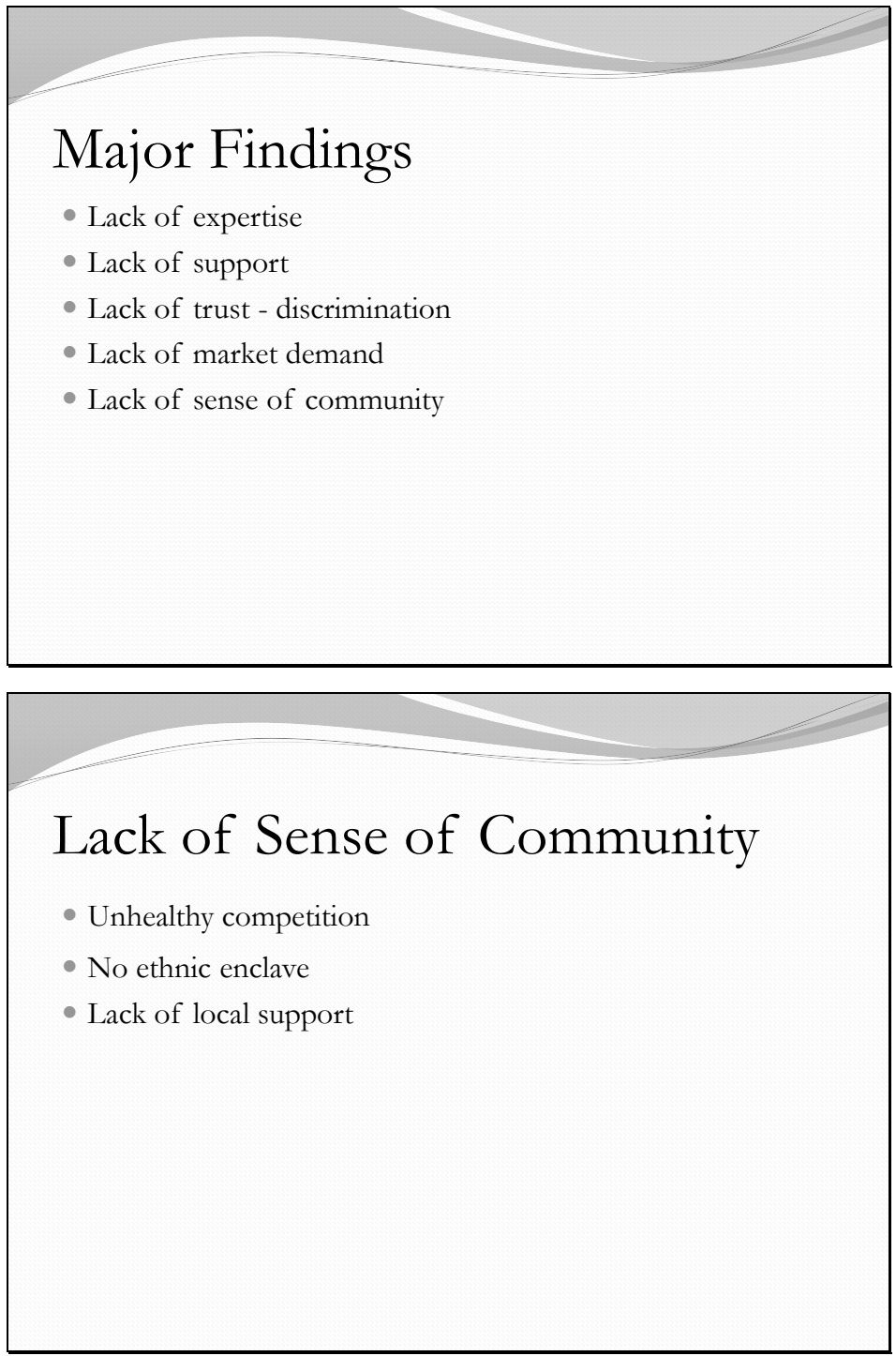

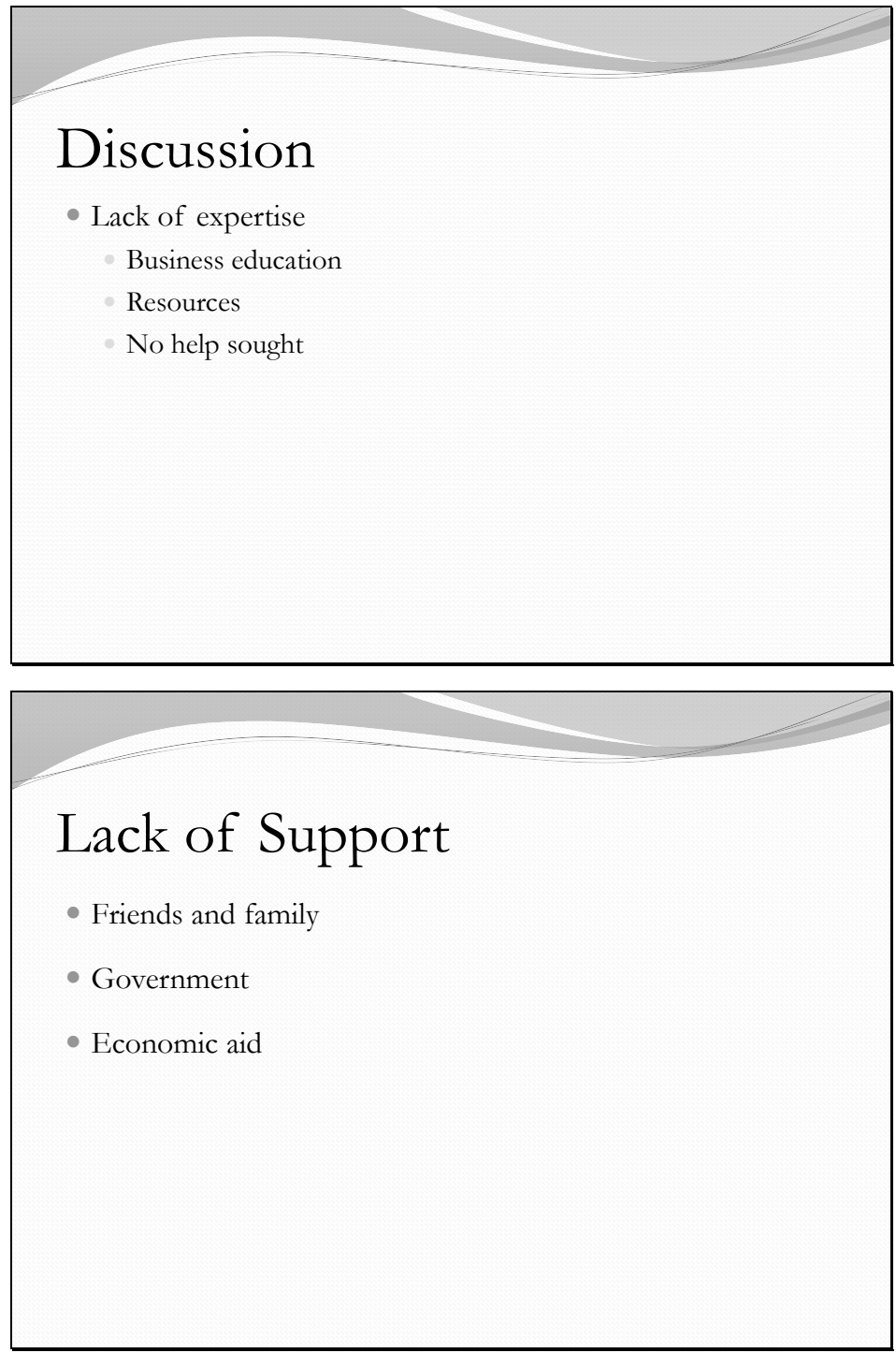

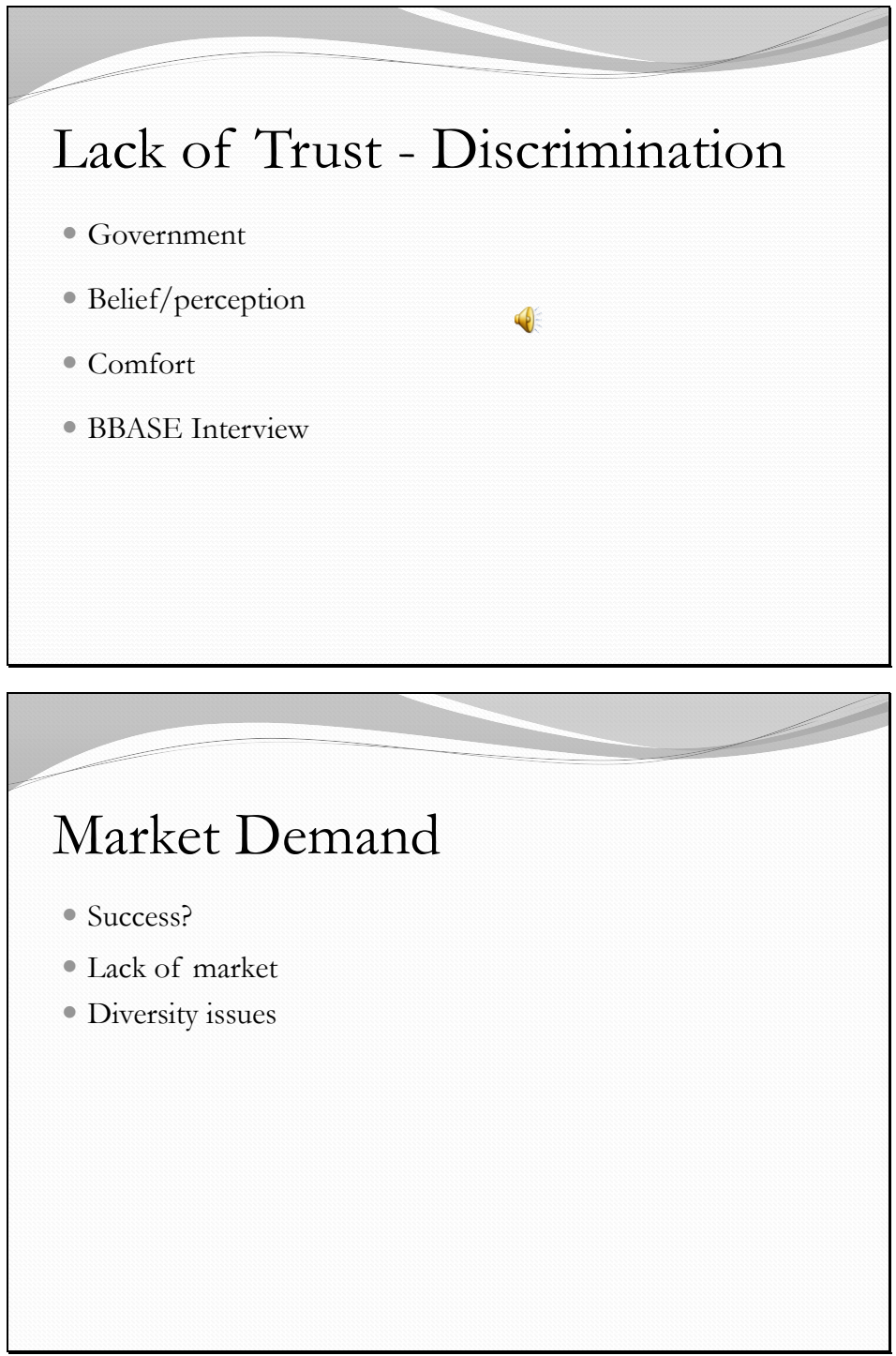

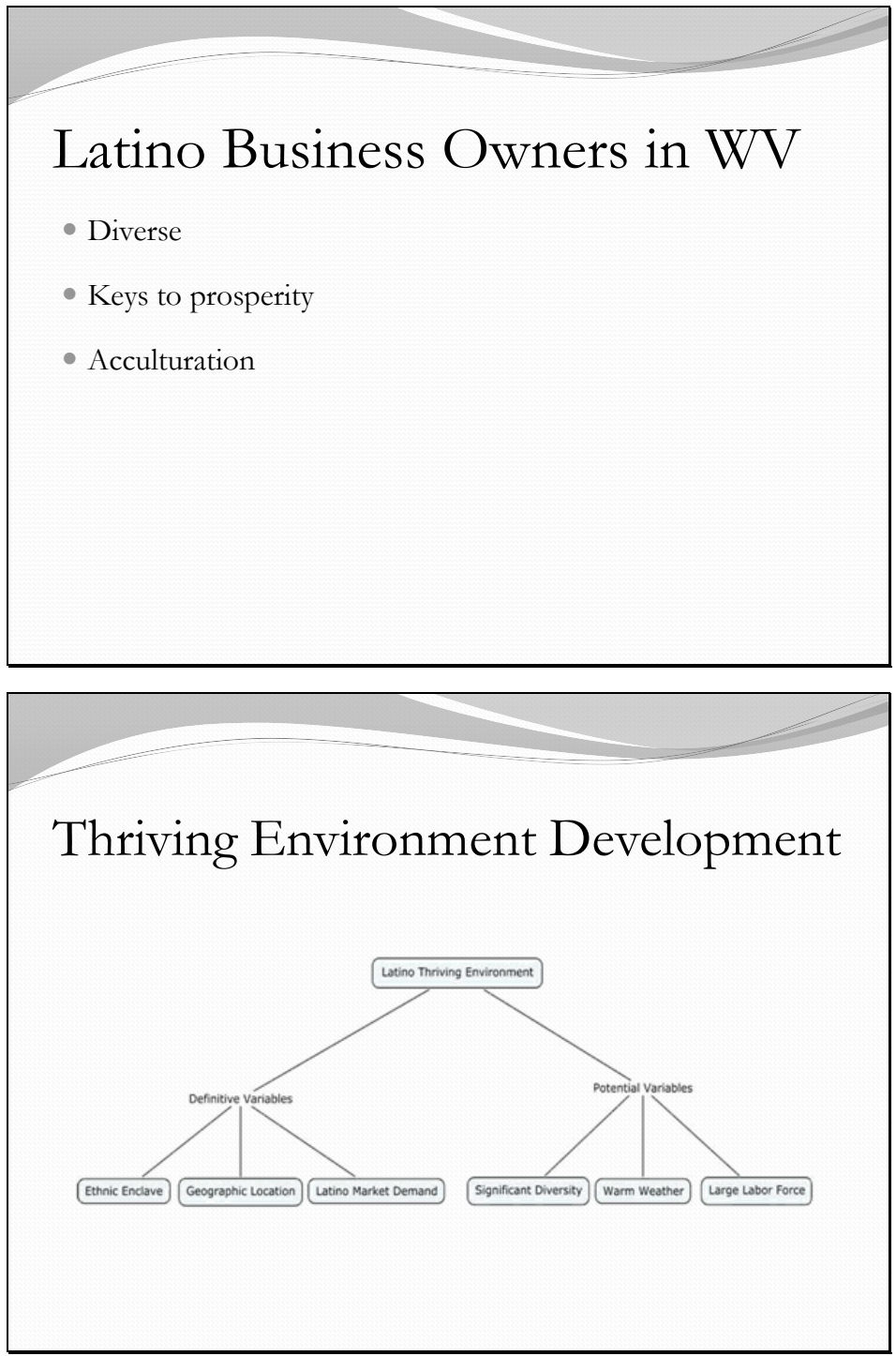

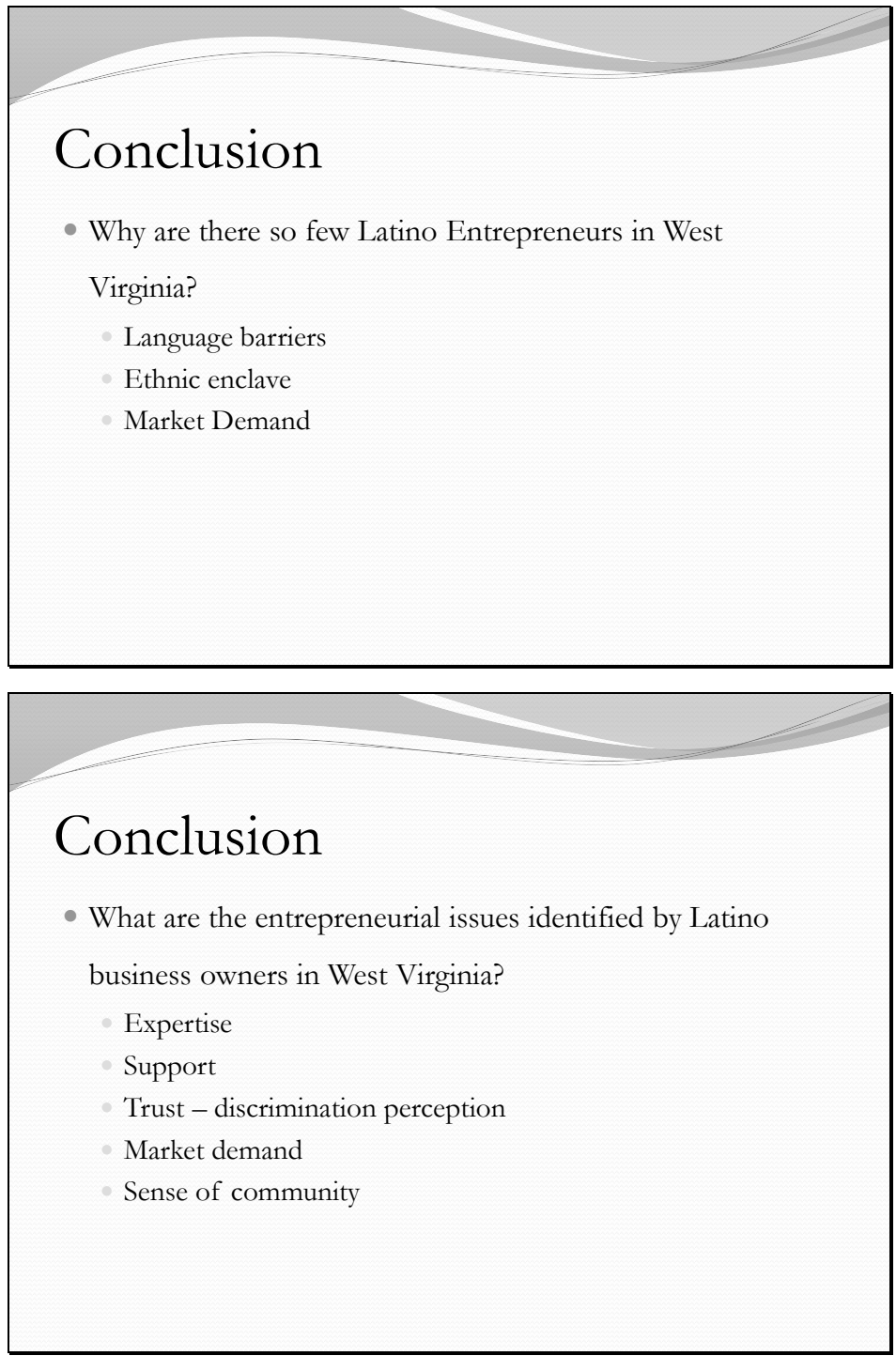

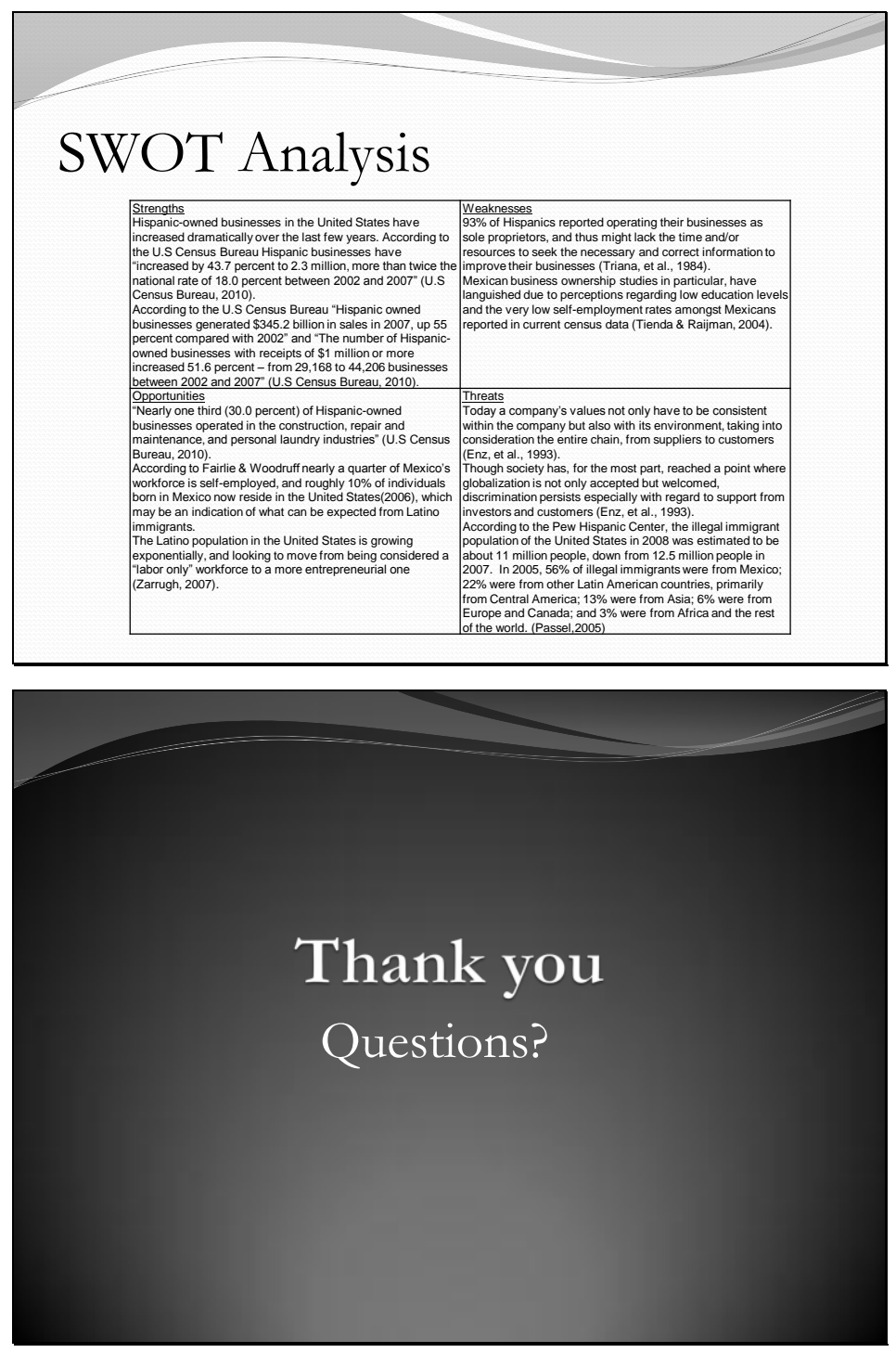